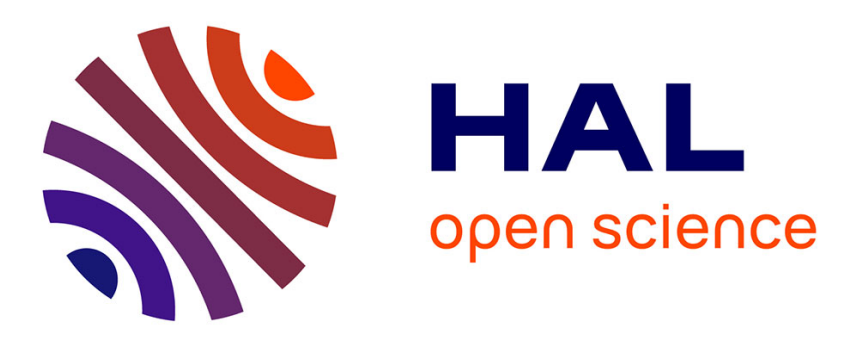

\title{
Relating collisional kinematics to exhumation processes in the Eastern Alps
}

\author{
Claudio L Rosenberg, S. Schneider, A. Scharf, A. Bertrand, K.
} Hammerschmidt, A. Rabaute, Jean-Pierre Brun

\section{- To cite this version:}

Claudio L Rosenberg, S. Schneider, A. Scharf, A. Bertrand, K. Hammerschmidt, et al.. Relating collisional kinematics to exhumation processes in the Eastern Alps. Earth-Science Reviews, 2018, 176, pp.311-344. 10.1016/j.earscirev.2017.10.013 . insu-01632819

\section{HAL Id: insu-01632819 https://hal-insu.archives-ouvertes.fr/insu-01632819}

Submitted on 10 Nov 2017

HAL is a multi-disciplinary open access archive for the deposit and dissemination of scientific research documents, whether they are published or not. The documents may come from teaching and research institutions in France or abroad, or from public or private research centers.
L'archive ouverte pluridisciplinaire HAL, est destinée au dépôt et à la diffusion de documents scientifiques de niveau recherche, publiés ou non, émanant des établissements d'enseignement et de recherche français ou étrangers, des laboratoires publics ou privés. 


\section{Accepted Manuscript}

Relating collisional kinematics to exhumation processes in the Eastern Alps

Claudio L. Rosenberg, S. Schneider, A. Scharf, A. Bertrand, K. Hammerschmidt, A. Rabaute, J.-P. Brun

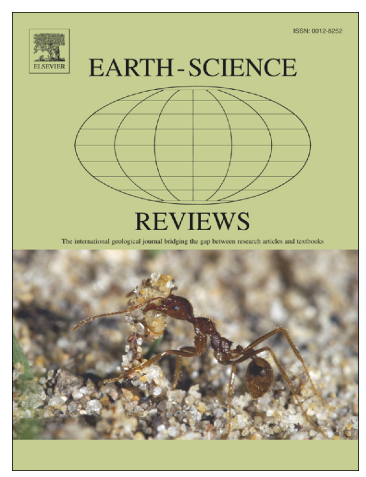

PII: $\quad$ S0012-8252(17)30163-0

DOI: $\quad$ doi:10.1016/j.earscirev.2017.10.013

Reference: $\quad$ EARTH 2513

To appear in: $\quad$ Earth-Science Reviews

Received date: $\quad 23$ March 2017

Revised date: $\quad 24$ October 2017

Accepted date: $\quad 24$ October 2017

Please cite this article as: Claudio L. Rosenberg, S. Schneider, A. Scharf, A. Bertrand, K. Hammerschmidt, A. Rabaute, J.-P. Brun , Relating collisional kinematics to exhumation processes in the Eastern Alps. The address for the corresponding author was captured as affiliation for all authors. Please check if appropriate. Earth(2017), doi:10.1016/ j.earscirev.2017.10.013

This is a PDF file of an unedited manuscript that has been accepted for publication. As a service to our customers we are providing this early version of the manuscript. The manuscript will undergo copyediting, typesetting, and review of the resulting proof before it is published in its final form. Please note that during the production process errors may be discovered which could affect the content, and all legal disclaimers that apply to the journal pertain. 


\section{Relating collisional kinematics to exhumation processes in the Eastern Alps}

Claudio. L. Rosenberg ${ }^{1,2}$, Schneider, S. ${ }^{3}$, Scharf, A. ${ }^{4}$, Bertrand, A. ${ }^{5}$, Hammerschmidt, K. ${ }^{6}$, Rabaute, A. ${ }^{1,2}$, and Brun, J.-P. ${ }^{7}$

1: Sorbonne Universités, UPMC, Institut de Sciences de la Terre Paris

2: UMR7193UPMC-CNRS, 4 place Jussieu, 75252, Paris Cedex 05, France

3: Department of Tectonophysics, Technische Universität, Bergakademie Freiberg, Germany

${ }^{4}$ : Sultan Qaboos University, P.O. Box 36, Al-Khawd, P.C. 123, Muscat, Sultanate of Oman

5: Hungarian Academy of Sciences, Budapest, Hungary

6: Department of Geology, Freie Universität Berlin, Malteserstraße 74-100, 12249 Berlin, Germany

7: Géosciences Rennes UMR 6118 Université de Rennes1, Campus de Beaulieu, 35042 Rennes Cedex, France

Abstract

Based on a review of the surface and deep structure of the Eastern Alps, we link the timing and the inferred displacement fields to exhumation of upper and lower crustal units of the orogenic nappe stack during collision. The discussion focuses mainly on the Tauern Window and its country rocks, the only area of the Eastern Alps where the orogenic wedge, from its uppermost Austroalpine nappes down to 
its deepest European basement nappes is continuously exposed. We summarize and discuss the long-standing controversy on the mechanisms of exhumation of this nappe stack on the base of a synthesis of structural and geochronological data, and restorations of collisional displacements, both in cross sections and map views. We conclude that the large amounts of exhumation assessed for the western Eastern Alps resulted from large amounts of thickening and erosion, not observed in the eastern part of the Eastern Alps. Extensional faults, laterally bounding the area of major thickening and exhumation are inferred to nucleate in order to accommodate displacement around the indenter corner in the west, and in order to reduce a large gradient of crustal thickness and surface elevation in the East.

Restorations to the pre-indentation stage, document an amount of northward increasing orogen-parallel extension, varying $45 \mathrm{~km}$ to $85 \mathrm{~km}$, corresponding to 15 $\%$ of extension, that is partly accommodated along normal faults. N-S shortening between the Northern Calcareous Alps and the Dolomites Indenter attained $75 \mathrm{~km}$ in the west and decreased to $30 \mathrm{~km}$ in the east. $55 \mathrm{~km}$ out of these 75 were accommodated in the area of the Tauern Window. Our kinematic model shows that lateral extrusion accommodated along conjugate strike-slip faults requires large amounts of north-south shortening in the western part of the Eastern Alps. Such shortening is consistent with the reconstructed upright folding and erosion of the Tauern Window, thus explaining the largest amount of its exhumation. In contrast, the eastern termination of the Eastern Alps represents an area where collisional convergence was barely accommodated by crustal thickening. This transition from a highly shortened, thickened and exhumed wedge in the west, mainly affected by orogen-perpendicular displacements, to a barely shortened and exhumed wedge in the east, mainly charcterised by orogen-parallel displacements, spatially coincides 
with a change in the deep structure of the European slab. Indeed, the inferred continental, European Slab, imaged in the west disappears into a low velocity anomaly, where no slab is detected in the east. An inherited step in the geometry in map view of the European passive margin, causing its crust to enter the subduction zone earlier than the area east of the Tauern Window, may explain the rapid decrease of shortening, of thickening, the different syn-collisional P-T gradients, and the disappearance of the continental slab east of the Katschberg Fault.

\section{Introduction}

Exhumation of basement units within the thickened lower plate of orogens generally occurs close to the plates interface, during advanced stages of collision (e.g., Eastern Alps: Brügel et al., 2003; Pyrenees: Muñoz, 1992; Taiwan: Beyssac et al., 2007; Zagros: Vergès et al. 2011). This process is generally associated to the formation of basement-rooted thrusts that create large antiformal structures, whose uplift and erosion allow for their exhumation. However, orogen-parallel extension affects the collisional stage of numerous orogens (Carpathians: Schmid et al., 1998; Central Coast Mountains, Canada: Klepeis and Crawford, 1999; Tibet: Cooper et al., 2015; Johnson, 2002; Molnar and Tapponnier, 1975; Himalaya: Xu et al., 2013; Taiwan: Mouthereau et al., 2009), including the Alps (e.g., Steck; 1980; Mancktelow, 1985; Selverstone, 1988; Behrmann, 1988; Ratschbacher et al., 1989), and in particular their eastern termination, where collision is inferred to have induced lateral extrusion of the orogenic wedge (Ratschbacher et al., 1991a). Hence, both vertical extension by crustal thickening and orogen-parallel extension commonly contribute to the accommodation of collisional convergence in these orogens. 
Because the first is generally associated to erosion and the second to the activity of normal faults, both processes contribute to exhumation of deep-seated crust.

The ratio between vertical thickening and orogen-parallel extension is a matter of debate in most orogens, in particular in the Alps (e.g., Linzer et al., 2002; Rosenberg et al., 2007), and in the Himalaya/Tibet (e.g., Houseman and England, 1993; Johnson, 2002). The relative contribution of each of these processes to the accommodation of convergence is fundamental for the understanding of the mechanisms of exhumation, for the reconstruction of paleogeography, and for the estimate of erosion rates and sediment flux to the foreland basins (Kuhlemann et al., 2001, 2002). 

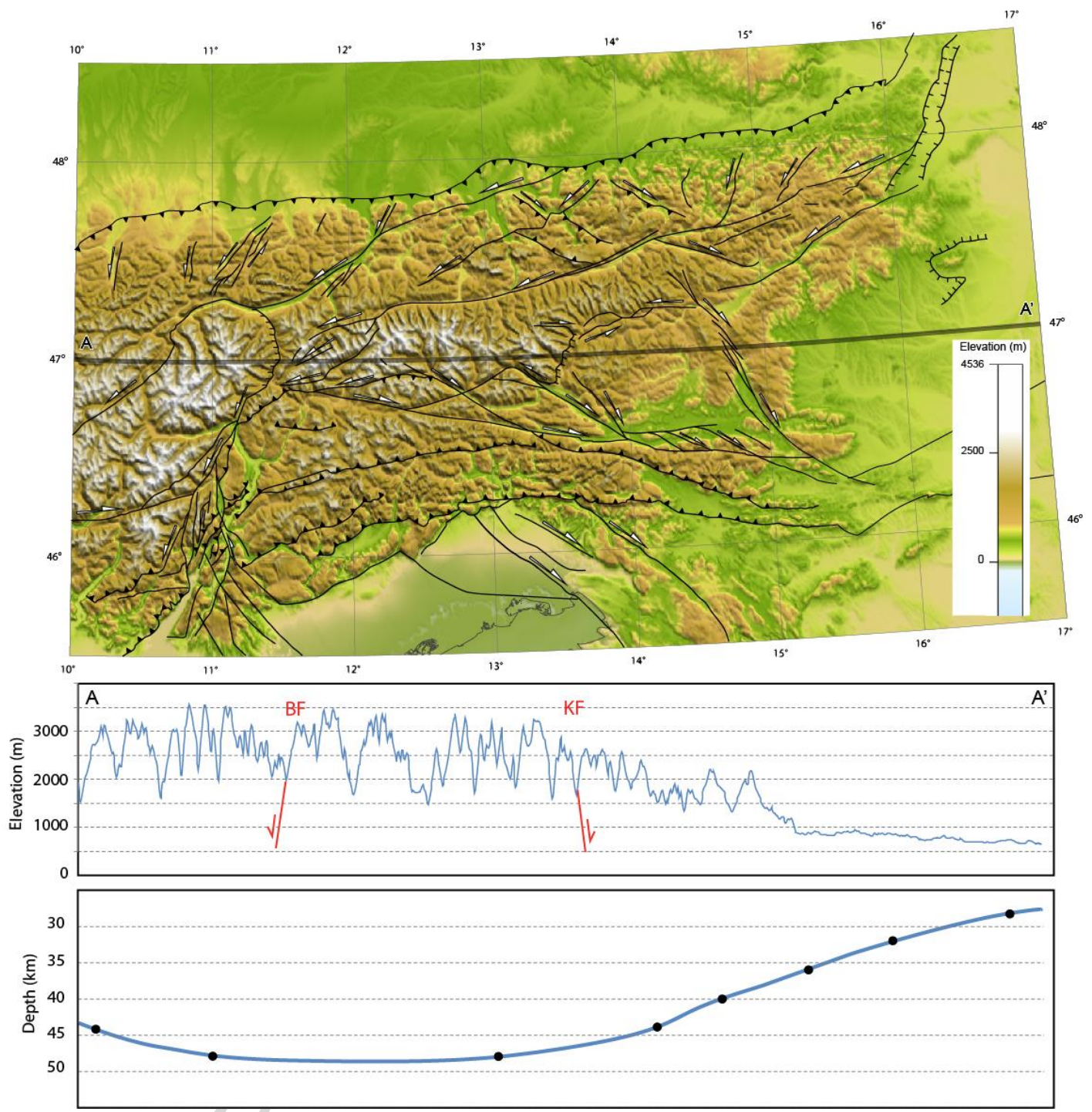

Fig. 1. Topographic map of the Eastern Alps and cross section along $47^{\circ}$ latitude, showing both surface topography and Moho depth. BF: Brenner Fault; KF: Katschberg Fault. Moho depth (gray circles) is taken from Spada et al. (2013).

In the Eastern Alps (Fig. 1), collisional exhumation is essentially localized within one area, the Tauern Window (Figs. 2, 3), a metamorphic dome exposing the lowest units of the orogenic wedge in its core. With the exception of the smaller Rechnitz-Eisenberg windows at the boundary between the Alps and the Pannonian Basin (Fig. 2), everywhere else in the Eastern Alps, the uppermost units of the Alpine nappe stack, namely the Austroalpine, are exposed (Fig. 2). This style of 
localised exhumation is not observed in the Western and Central Alps, where the deepest parts of the collisional wedge, i.e. the European and/or Briançonnais basement nappes, are exposed at the surface nearly continuously along the strike of the chain (e.g., Bigi et al., 1990; Bousquet et al., 2012).

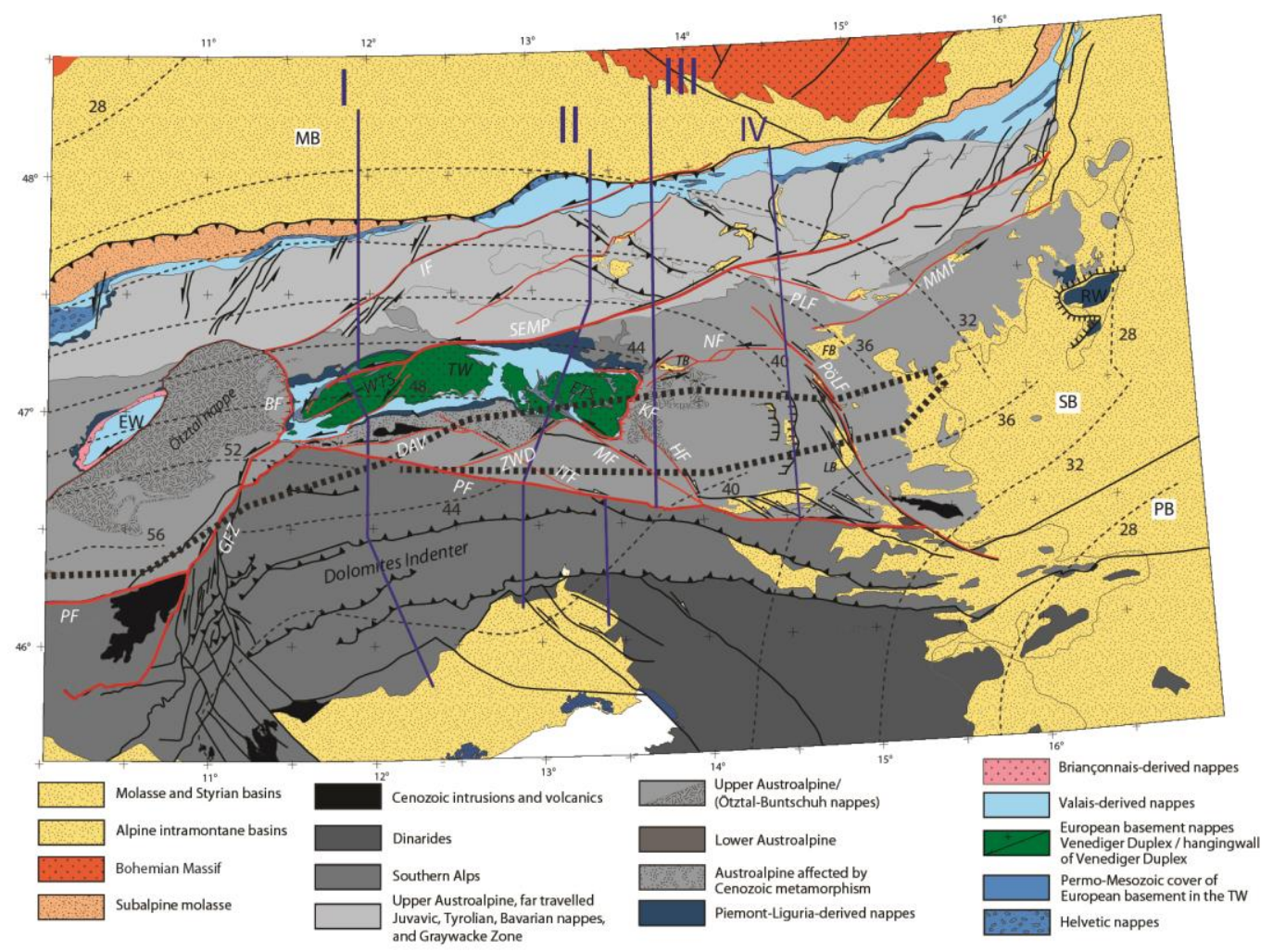

Fig. 2. Tectonic maps of the Eastern Alps. Simplified and modified from Bigi et al. (1990) and Bousquet et al. (2012). Stippled black lines and italic numbers: Moho contour lines with corresponding depth in km, after Spada et al. (2013). Stippled lines: boundary zone between Adriatic and European Moho, where the depth of the Moho is not resolved (Spada et al., 2013). Faults marked in red represent the major Cenozoic faults north of the SouthAlpine Indenters. EW: Engadine Window; RW: Rechnitz Window; TW: Tauern Window; FB: Fohnsdorf Basin; LB: Lavanttal Basin; TB: Tamsweg Basin; BF: Brenner Fault; DAV: Defereggen-Antholz-Vals Fault; HF: Hochstuhl Fault; GFS: Giudicarie Fault System; IF: Inntal Fault; ITF: Iseltal Fault; KF: Katschberg Fault; MF: Mölltal Fault; MMF: Mur-Mürz Fault; NF: Niedere Tauern Southern Fault; PF: Periadriatic Fault; PLF: Palten-Liesing Fault; PöLF: PölsLavanttal Fault; SEMP: Salzach-Enns-Mariazell-Puchberg Fault; ZWD: ZwischenbergenWöllatratten-Drau Fault. 


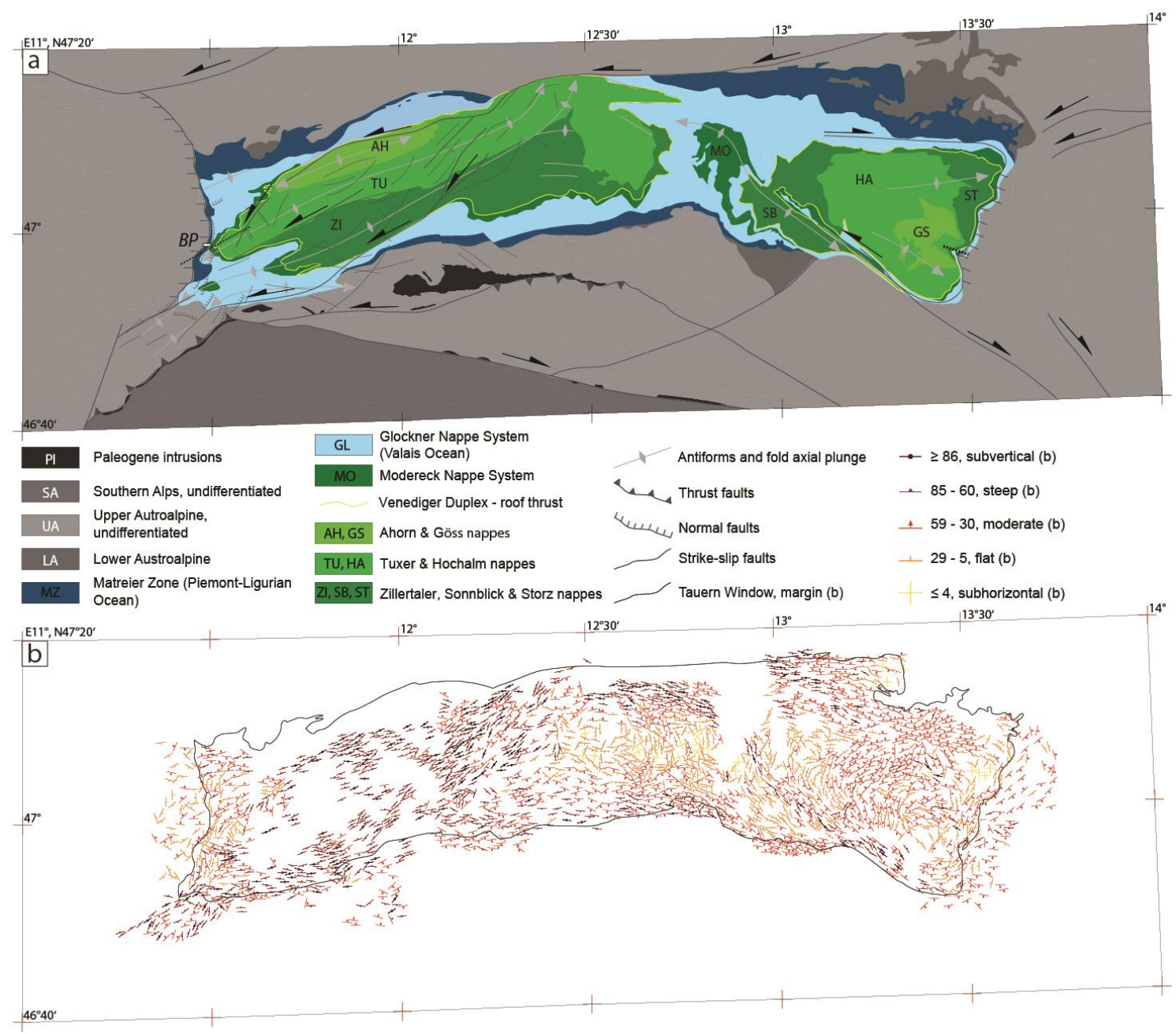

Fig. 3. Tectonic and structural maps of the Tauern Window. a) Tectonic map of the Tauern Window and surrounding areas, showing the trace of the major fold axial planes and shear zones, and the major nappe contacts following Schmid et al. (2013). BP: Brenner Pass. Tectonic map modified from Schmid et al., 2013 and Bigi et al., 1990. Stippled black line at the western termination of Tauern Window is the trace of sections in Fig. 11. Stippled black line at the eastern margin of Tauern Window is the trace of section of Fig. 14. b) Tectonic map of the Tauern Window and surrounding areas, showing the trace of main foliation in map view. Foliations compiled from Exner (1956, 1962, 1964, 1980, 1983, 1991, 1996); Frank and Pestal (2008); Scharf et al. (2013a) and Schneider (2014).

This style of exhumation is still a matter of debate. Historically, exhumation was considered to result exclusively from folding and erosion (Termier, 1903; Dal Piaz, 1934; Cornelius, 1940; Roeder, 1989), because the first attempts to understand 
the structure of the Eastern Alps were based on the construction of cross sections perpendicular to the strike of the orogen, showing that the Tauern Window coincided with a large antiformal structure eroded in its core (Fig. 4). However, at the end of the '80ies, after the concept of extensional core complex (e.g., Armstrong, 1982; Lister and Davis, 1989) became popular, the western margin of the Tauern Window was recognized as a syn-collisional Oligo-Miocene, top-to-the-West, lowangle normal fault (Brenner Fault, Behrmann, 1988; Selverstone, 1988). Cross sections constructed parallel to the orogen (Selverstone, 1988) showed the omission of several Austroalpine nappes along the Brenner Fault, suggesting that large extensional displacements had taken place and contributed to the exhumation of the dome during collision. A similar structure was recognized at the eastern termination of the dome (Genser and Neubauer, 1989), leading to the idea that the entire Tauern Window was an extensional core complex (Frisch et al., 2000). The following 15 years of research brought more details on the age difference between footwall and hangingwall (Fügenschuh et al., 1997), on the mechanisms of extensional unroofing (Axen et al., 1995; Selverstone et al., 1995; Wawrzyniec et al., 2001), and on the amount of extension accommodated by the Brenner Fault (Axen et al., 1995; Fügenschuh et al., 1997). At the same time, new geodynamic models of collision in the Eastern Alps (Ratschbacher et al., 1991a, b; Linzer et al., 2002; Sperner et al., 2002) gave a rational geodynamic frame to explain large amounts of orogen-parallel extension during collision. Two major geodynamic processes were inferred to trigger orogen-parallel extension in the Eastern Alps: subduction-roll back, below the Carpathians (Royden et al., 1982), and lateral extrusion, i.e., the combined effect of gravity collapse and lateral escape of material from the thickened orogenic wedge (Fig. 2). 
This largely accepted view of shortening accommodated by orogen-parallel flow was questioned (Rosenberg et al., 2004) after the interpretations of a seismic section through the Eastern Alps (TRANSALP, Fig. 4; Gebrande et al., 2002; Schmid et al., 2004; Castellarin et al., 2006; Lammerer et al., 2011; Rosenberg et al., 2015) corroborated previous sections (Fig. 4) showing that significant folding, in the footwall of the Brenner Fault, was associated with crustal-scale thickening and not with thinning. Hence, new interpretations suggested that exhumation of the Tauern Window occurred mainly by folding and erosion (Rosenberg et al., 2004; 2007; Glodny et al., 2008; Rosenberg and Garcia, 2011; 2012; Schneider et al., 2015). Nonetheless, the debate remains open and extensional unroofing is still claimed to be a major mechanism of exhumation (Wölfler et al., 2011; Fügenschuh et al., 2012; Scharf et al., 2013a).

Much of the controversy stems from the fact that the Tauern Window consists of two major post-nappe structures: upright folds of high amplitude forming the dome and accommodating north-south shortening, and normal faults, forming the lateral boundaries of the dome, accommodating orogen-parallel extension. It is a major aim of this paper to discuss these structures in more detail and to assess to which degree they both contributed to the exhumation of the Tauern Window.

New data on tectonics (Scharf et al., 2013a; Schmid et al., 2013; Bertrand et al., 2015; Schneider et al., 2015; Favaro et al., 2017), deep structure (Behm et al., 2007; Brückl et al., 2007, 2010; Mitterbauer et al., 2011; Spada et al., 2013; Qorbani et al., 2015; Zhao et al., 2016), Barrovian metamorphism (Scharf et al., 2013b; Schneider et al., 2014; Cliff et al., 2015; Favaro et al., 2015), geochronology (Glodny et al., 2008; Wölfler et al., 2008; Nagel et al., 2013; Schneider et al., 2013, 2015; 
Bertrand et al., 2015; Cliff et al., 2015; Favaro et al., 2015; Scharf et al., 2016,

Heberer et al., 2017), and geodynamics (Wölfler et al., 2011; Luth et al., 2013;

Favaro et al., 2017; van Gelder et al., 2017) of the Eastern Alps have been published recently. The aim of the present paper is to give an overview, based on these and older works, on the links between kinematics and exhumation during collision in the Eastern Alps, and to discuss first, why the lower part of the orogenic wedge is only exposed within a single area of limited extent (Tauern Window; Fig. 2), and second, which mechanisms drove syn-collisional exhumation of lower-plate fragments in the same area.
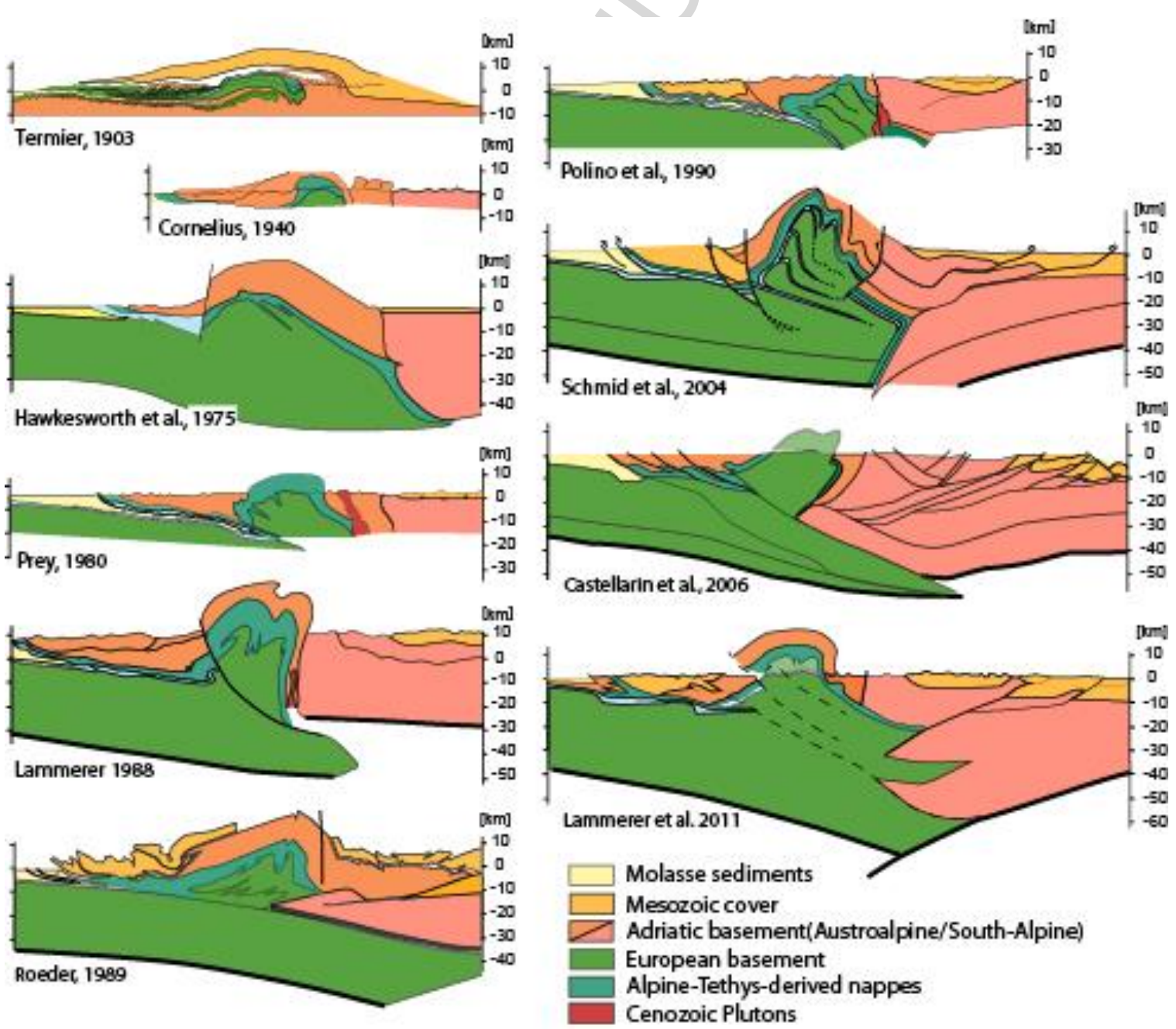
Fig. 4. Orogen-scale sections of the Eastern Alps, striking across the western Tauern Window. Note that from the 1970's onwards, all sections depict stacking and folding of European crust creating an antiformal structure that thickens the crust by 20 to $>50 \mathrm{~km}$ below the Tauern Window.

\section{Geological Setting}

In this paper the Eastern Alps are defined as the area delimited by the Brenner Fault in the west, the Styrian Basin in the east, the Molasse Basin in the north, and the Southern Alps in the south (Fig. 1). Throughout this paper, we will define collision as the process accommodating convergence by shortening of the European and/or Adriatic continental plates, following a phase of nappe stacking during limited subduction of the distal European margin. Collision is inferred to be associated with the development of the Molasse basins in the foreland and with an increasing geothermal gradient, culminating in the Barrovian metamorphism recorded in the thickened orogenic wedge. Collision is still ongoing today (e.g., D’Agostino et al., 2005), and it is inferred to have started during the Early Oligocene based on the stratigraphy of the North- Alpine Foreland Basin (Sissingh, 2006). As a consequence, we define collisional exhumation as a process, taking place from the Early Oligocene to the present.

The eastern part of the Southern Alps (Fig. 1) that is bounded in the west by the sinistral Giudicarie Fault System forms the Dolomites Indenter (Fig. 2). The term indentation will be used to describe shortening accommodated north of the Periadriatic Fault that is inferred to be kinematically linked to sinistral displacements along the Giudicarie Fault System. Hence, irrespective of the significant amount of shortening taking place within the Southern Alps (Doglioni, 
1987; Schönborn, 1999; Nussbaum, 2000), indentation expresses that part of collisional shortening due to the differential northward displacement of the Dolomites Indenter (Fig. 1). Below, we give an overview of the collision history of the Eastern Alps, based on geophysical, geological, petrological and geochronological data,

\section{II.1. Geophysical data}

The actual depth of the European and Adriatic Moho along their interface cannot yet be imaged precisely because a data gap still exists (Fig. 2; Behm et al., 2007; Spada et al., 2013). However, contour lines of the Moho depth (Fig. 2) and previous studies (Polino et al., 1990; Nicolich and Dal Piaz, 1991; Waldhauser et al., 2002; Castellarin et al., 2006; Behm et al., 2007; Brückl et al., 2010; Spada et al., 2013) in the western Tauern Window suggest that the European plate dips southward attaining $>50 \mathrm{~km}$ depth under the Periadriatic Fault, whereas the Moho of the Adriatic plate, dips northward attaining $\sim 44 \mathrm{~km}$ below the Periadriatic Fault. We therefore define them respectively, as lower and upper plates, when discussing the collisional history of the Eastern Alps. This interpretation is consistent with teleseismic tomography (Mitterbauer et al., 2011) imaging a deep slab attached to the European plate throughout the Central Alps, and up to $14^{\circ}$ longitude in the Eastern Alps, i.e. all along the area of the Tauern Window. The strike and depth of the Moho east of the Tauern Window rotate into different orientations. The European Moho turns into a NW-SE strike and the Adriatic one into a NE-SW strike (Fig. 2) and both Mohos appear to meet at the same depth in the Styrian Basin (Fig. 2).

Based on reflection-seismic sections and P-wave tomography different interpretations of the deep structure of this area exist. One model considers the 
Adriatic plate to be in an upper plate position with respect to the European Plate all along the central and western part of the Eastern Alps (Kummerow et al., 2004; Behm et al., 2007; Brückl et al., 2010; Mitterbauer et al., 2011). Only east of the Tauern Window the Adriatic plate turns into a lower plate position, where it subducts eastward forming the Dinaric Chain (Doglioni and Carminati, 2002). Other interpretations (e.g., Schmid et al., 2013), based on previous results of P-wave tomography (Lippitsch et al., 2003), favor a change of slab-dip direction below the Tauern Window, after 30 Ma (Handy et al., 2014). This change was made possible by the inferred breakoff of the European slab below the Eastern Alps (Qorbani et al., 2015). However, tomographic profiles through the ALPASS model (Mitterbauer et al., 2011) suggest that slab detachment only occurs east of $14^{\circ}$ longitude, i.e. east of the Tauern Window (Fig. 2). A third group of models suggests the existence of a "Pannonian Plate" wedging out to the West, at the southeastern margin of the Tauern Window (Behm et al., 2007; Brückl et al., 2010; Mitterbauer et al., 2011). The latter plate would be in an upper plate position with respect to both the Adriatic and the European plates.

The area of the Tauern Window (Fig. 2) is located above a positive mantlevelocity anomaly (Lippitsch et al., 2003; Piromallo and Morelli, 2003; Koulakov et al., 2009; Mitterbauer et al., 2011; Zhao et al., 2016) that continues subvertically to at least $250 \mathrm{~km}$ depth (Mitterbauer et al., 2011). This anomaly appears to be laterally continuous with the one striking below the Central Alps, further west, and it is interpreted as European Slab by some authors (Mitterbauer et al., 2011), but as Adriatic (Lippitsch et al., 2003; Schmid et al., 2004; Handy et al. 2015) and Dinaric (Zhao et al., 2016) by others. 


\section{II.2. Tectono-stratigraphic architecture of the Eastern Alps}

Since the analogy between "Bündnerschiefer" in the Tauern Window and "Schistes Lustrés" in the Western Alps was recognized (Studer, 1851; Termier, 1903), the nappe concept was extended to the Eastern Alps, whose crustal structure was shown to consist of a pile of metamorphic nappes (Termier, 1903) that are all exposed within the Tauern Window and its surroundings (Figs. 2; 3a; Thiele, 1980). There, an elongate core of European (Thiele, 1980; Lammerer and Weger, 1998; Neubauer et al., 1999; Veselá et al., 2008) basement nappes with thin relics of its inferred Helvetic-type (Thiele, 1970, 1976, Frisch, 1974, Oehlke et al., 1993, Veselá et al., 2008), Mesozoic cover strikes parallel to the central axis of the Window (Figs. 2; 3a). This basement is enveloped first by the Glockner nappes (Fig. 3a), inferred to be relicts of the Piemont-Ligurian-ocean (Dal Piaz et al., 2003), or from the Valais Ocean (Bigi et al., 1990; Schmid et al., 2004; 2013) and then by nappes of the "Matreier Zone" inferred to be a relict of the Liguro-Piemont Ocean (Schmid et al., 2013). These three units are overlain by the Austroalpine nappes, which, are derived from the Adriatic continent and formed the upper plate of the Cenozoic Alpine Orogen during oceanic subduction. For a synthesis and detailed correlation between the nappes throughout the Eastern Alps, in addition to an interpretation of their paleogeographic origin, see Schmid et al. (2013).

The Austroalpine units, except for a small area southwest of the Tauern Window, show everywhere Cretaceous cooling ages, for geochronometers with closure temperatures $\geq 300{ }^{\circ} \mathrm{C}$ (Luth and Willingshofer, 2008). In contrast OligoMiocene cooling ages are found everywhere within the Tauern Window. Figure 5 shows that even zircon fission track ages are almost entirely Cretaceous around the Tauern Window. Consequently, the Eastern Alps may be viewed as a pile of nappes 
overlain by a large (Austroalpine) orogenic lid (Laubscher, 1983) that was lingering in the brittle field since the late Cretaceous.

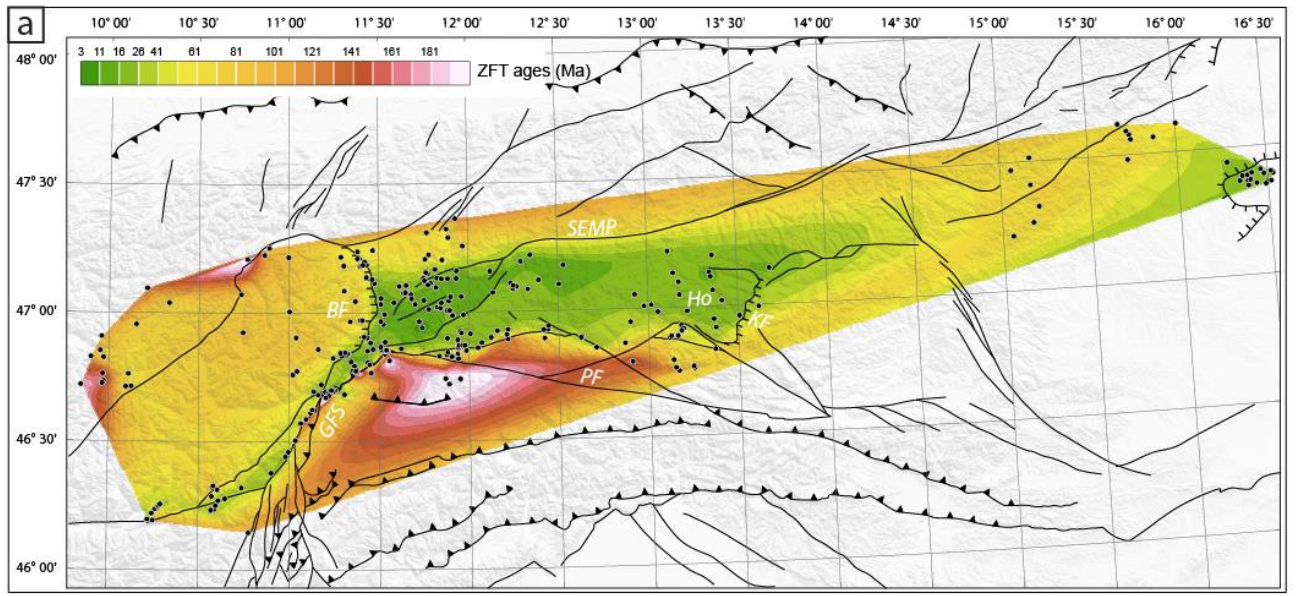




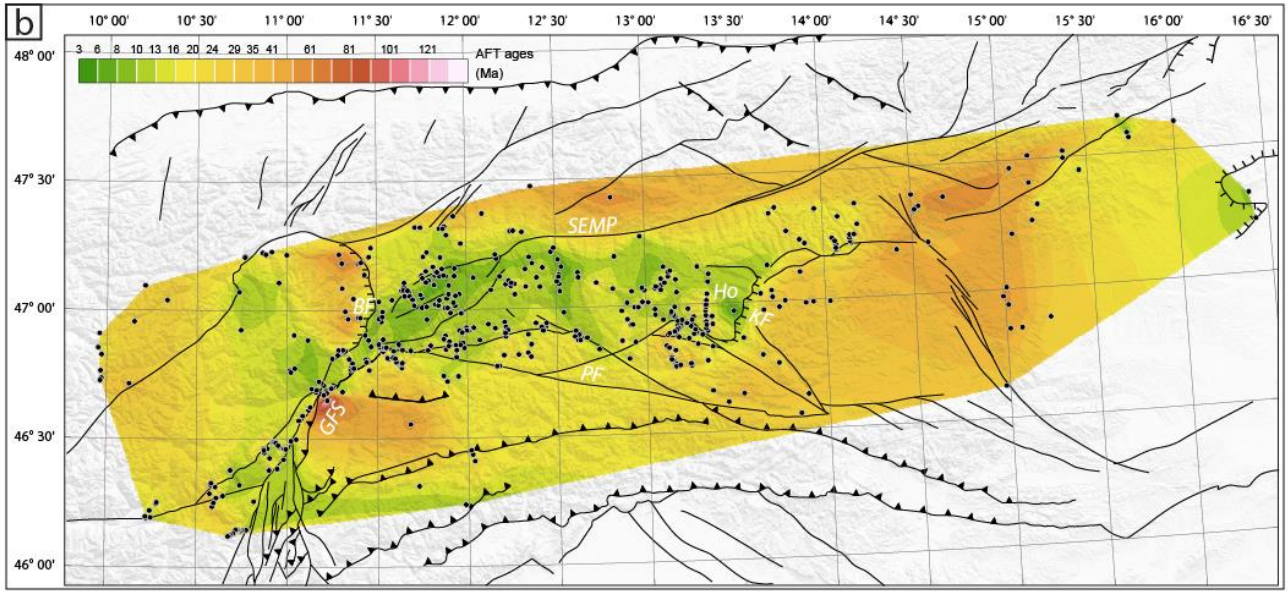

Fig. 5. Compiled cooling ages, derived from fission track analyses on a) zircons and b) apatites. Note that the colour table in a) and b) is different. BF: Brenner Fault; GFS: Giudicarie Fault System; KF: Katschberg Fault; PF: Periadriatic Fault; SEMP: SalzachEnnstal-Mariazell-Puchberg Fault. Ho: Hochalm Dome. Data source: Bertrand et al. (2017); Coyle et al., 1994; Dunkl and Demeny 1997; Dunkl et al., 2003; Elias, 1998; Di Fiore, 2013; Flisch et al., 1986; Fodor et al., 2008; Foeken et al., 2007; Fügenschuh et al., 1997; Grundmann and Morteani, 1985; Hejl, 1997; Martin et al., 1998; Most, 2003; Neubauer et al 1995; Pomella et al., 2010, 2012; Staufenberg, 1987; Steenken et al., 2002; Stöckli \& Fügenschuh, 1995; Stöckhert et al., 1999; van Gelder, 2017; Viola et al., 2001; Viola et al., 2003; Wölfler et al., 2008; Wölfler et al., 2012; Wölfler et al., 2015; Wölfler et al., 2016; Zattin et al, 2006. The choice of age classes of the interpolated maps is based on the analysis of the distribution histograms of apatite and zircon fission track ages. Interpolation of fission track ages was performed using the natural neighbor algorithm provided by ESRIArcMap10tm GIS Software.

The complete structure of the East-Alpine orogen was first depicted by Termier (1903; Fig. 4), clearly showing orogen-scale thrusting of the Austroalpine units over the Glockner nappes and an antiformal, large-scale structure 
corresponding to the Tauern Window. Detailed mapping and careful constructions of serial sections (Bianchi, 1934; Dal Piaz, 1934). These studies served as a base for numerous, later constructions of orogen-scale cross sections through the Eastern Alps (Fig. 4) which integrated the results of seismic interpretation after the late 80'ies (Fig. 4; Cornelius, 1940; Prey, 1980; Lammerer, 1988; Roeder, 1989; Polino et al., 1990; Lammerer and Weger, 1998; Transalp Working Group, 2002; Schmid et al., 2004; Castellarin et al., 2006; Lammerer et al., 2011; Rosenberg et al., 2015).

In spite of widespread evidence for Neogene north-south-directed shortening in the Southern Alps (Castellarin and Vai, 1981; Doglioni, 1987; Doglioni and Bosellini, 1988), attaining an amount of $\sim 50 \mathrm{~km}$ (Schönborn, 1999; Nussbaum, 2000), and GPS data pointing to on-going internal shortening (D'Agostino et al. 2005; Doglioni et al., 2007; Cuffaro et al., 2010; Métois et al., 2015), the latter area has been classically modeled as an indenter (Ratschbacher et al., 1991a; Rosenberg et al., 2004, 2007; Robl and Stüwe, 2005; Caporali et al., 2013; van Gelder et al., 2017). Since the first half of the $20^{\text {th }}$ century, collisional structures in the thickened lower plate of the Eastern Alps were set in relationship to the approximately northward movement of the Dolomites Indenter (Fig. 2; e.g., Cornelius, 1940; Frisch et al., 2000). This interpretation relies on the following observations: 1) The orientation of main foliations and folds of the accreted lower plate, become parallel to the margin of the Dolomites Indenter in its vicinity, rotating by $\sim 50^{\circ}$ around its corner (Schneider, 2014; Fig. 3). 2) Large amounts of exhumation took place in front of the indenter, which was not affected by significant exhumation itself. 3) Collisional shortening in the Austroalpine units is very modest west of the Dolomites Indenter, where large-scale structures are not folded and gently dipping (Prey, 1977), but very intense north of the indenter, where the Austroalpine units 
are tightly folded with steep axial planes striking sub-parallel to the indenter margin.

\section{II.3. Structure and fabrics in the Tauern Window}
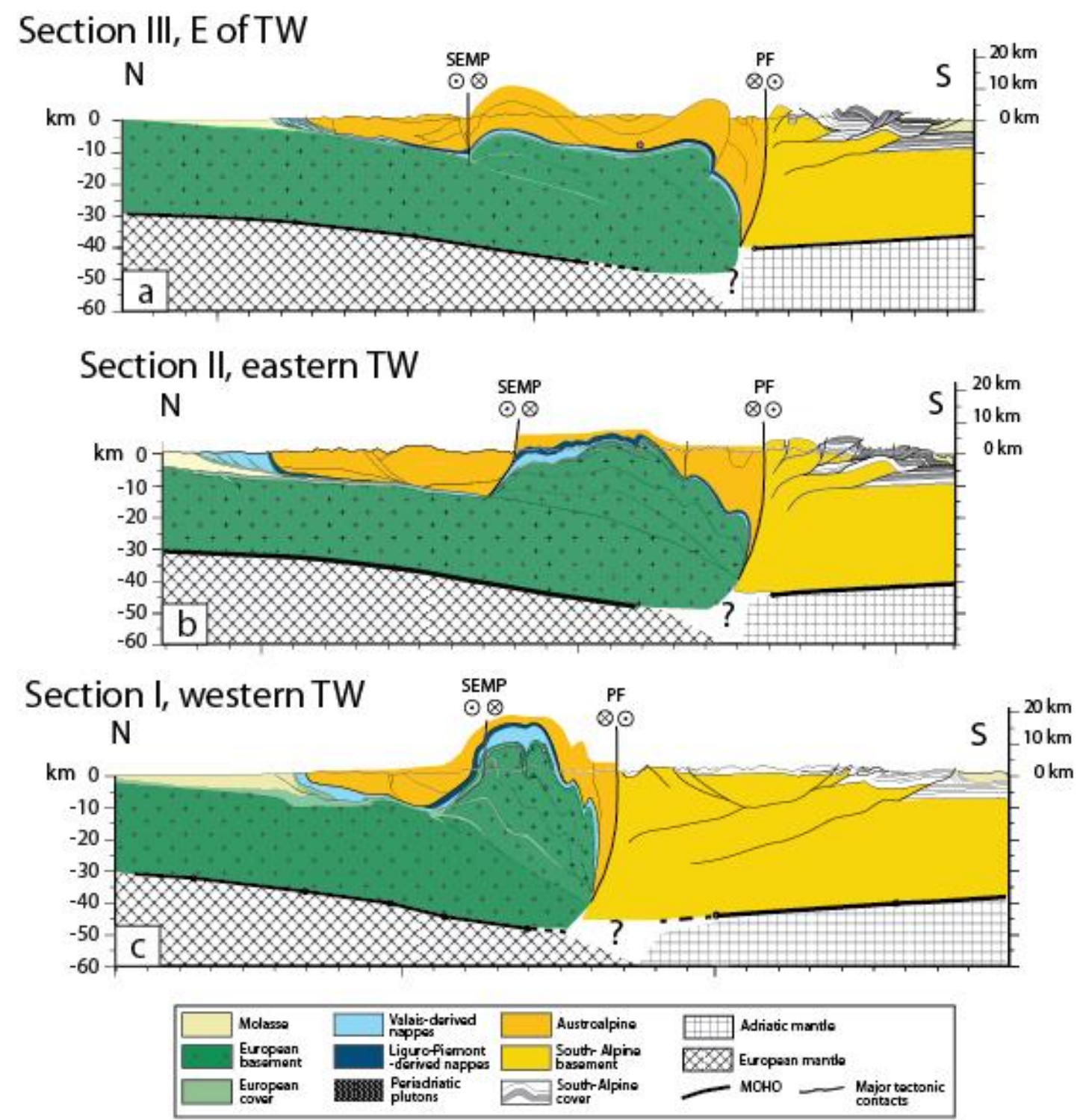

Fig. 6. Cross sections through the Eastern Alps, modified from Rosenberg et al. (2015). Traces of sections are shown in Fig. 2. The question marks correspond to stippled area of figure for which Moho depth cannot be defined (Spada et al., 2013).

The structure of the Tauern Window and its country rocks is shown by three orogenic-scale cross-sections in figure 6 (Rosenberg et al., 2015). The cross section 
of the eastern Tauern Window (Fig. 6b) shows the European basement thickened by an antiformal stack located between the Periadriatic Fault in the south and the Salzach-Ennstal-Mariazell-Puchberg (SEMP) Fault in the north. This stack doubles the thickness of the European basement compared to its original thickness below the northern foreland basin. Therefore, the top of the European basement nappes was uplifted by $15-20 \mathrm{~km}$ along the SEMP Fault (Fig. 6c), compared to its position further north. East of the Tauern Window (Fig. 6a), both the thickness of the European nappe stack and the amplitude of its upright folds are smaller than within the window. In contrast to the Central Alps, where the mylonitic belt of the Periadriatic Fault System localised a large, diferrential vertical displacement exhuming the European basement nappes, this differential, vertical displacement, leading to exhumation of the European nappes less localized in the Eastern Alps, and it only takes place in the Tauern Window, some 10's of km north of the Periadriatic Fault (Fig. 6).

Three nappes derived from the European basement, termed from top to bottom Zillertal-, Tuxer-, Ahorn nappes in the west and Göss-, HochalmRomate/Sonnblick/Storz in the east underly a fourth nappe of metamorphic Paleozoic and Mesozoic sediments (Schmid et al., 2013), and this entire pile forms a duplex structure (Lammerer and Weger, 1998) termed the Venediger Duplex (Schmid et al., 2013). It forms an antiformal stack in the west and a foreland dipping duplex in the east, that are further shortened into large-scale upright folds (D5 of Schmid et al., 2013; Fig. 6). These nappes are inferred to form during Early Cenozoic top-to-the-North syn-collisional thrusting (e.g., Schmid et al., 2013).

The amplitude of the latter antiformal stack (Fig. 6c) is unique for the entire Alpine chain (compare Fig. 6c with other Alpine cross sections in Schmid et al., 2004 
and Rosenberg and Kissling, 2013), and for most other collisional orogens. Other areas in the Alps where such large and thickened basement domes exist (e.g., Monte Rosa nappes), do not consist of European, but rather Briançonnais-derived units. Map-scale observations and cross-section interpretations, suggest that this antiformal stack largely disappears to the west (Rosenberg and Kissling, 2013) and to the east (Schmid et al., 2004; cross section of their Fig. 4e) of the Tauern Window. The structural grain of the Tauern Window is dominated by upright folds and transcurrent shear zones (Fig. 3), both striking sub-parallel to the long axis of the window (Glodny et al., 2008; Rosenberg and Schneider, 2008), and by two extensional fault systems, striking perpendicular to the window and defining its eastern and western boundaries (Figs. 1, 2 and 3). The eastern normal fault is termed the Katschberg Fault (Genser and Neubauer, 1989; Scharf et al., 2013a), the western one is the Brenner Fault (Behrmann, 1988; Selverstone, 1988), and both of them are associated to mylonitic belts attaining a maximum of $\sim 4-5 \mathrm{~km}$ thickness (Scharf et al., 2013a). The upright folds strike ENE in the west, and ESE in the east, defining two sub-domes, that we term western and eastern sub-domes, respectively (Fig. 2). The gradual, along-strike transition from the ENE to the WSW orientation, is also visible in the arcuate morphology of the Tauern topography (Fig. 7a). The amplitude of upright folds in the western Tauern Window attains several tens of $\mathrm{km}$ in map view (Fig. 3a), and some 10 to more than $25 \mathrm{~km}$ in cross section (Fig. 6). 

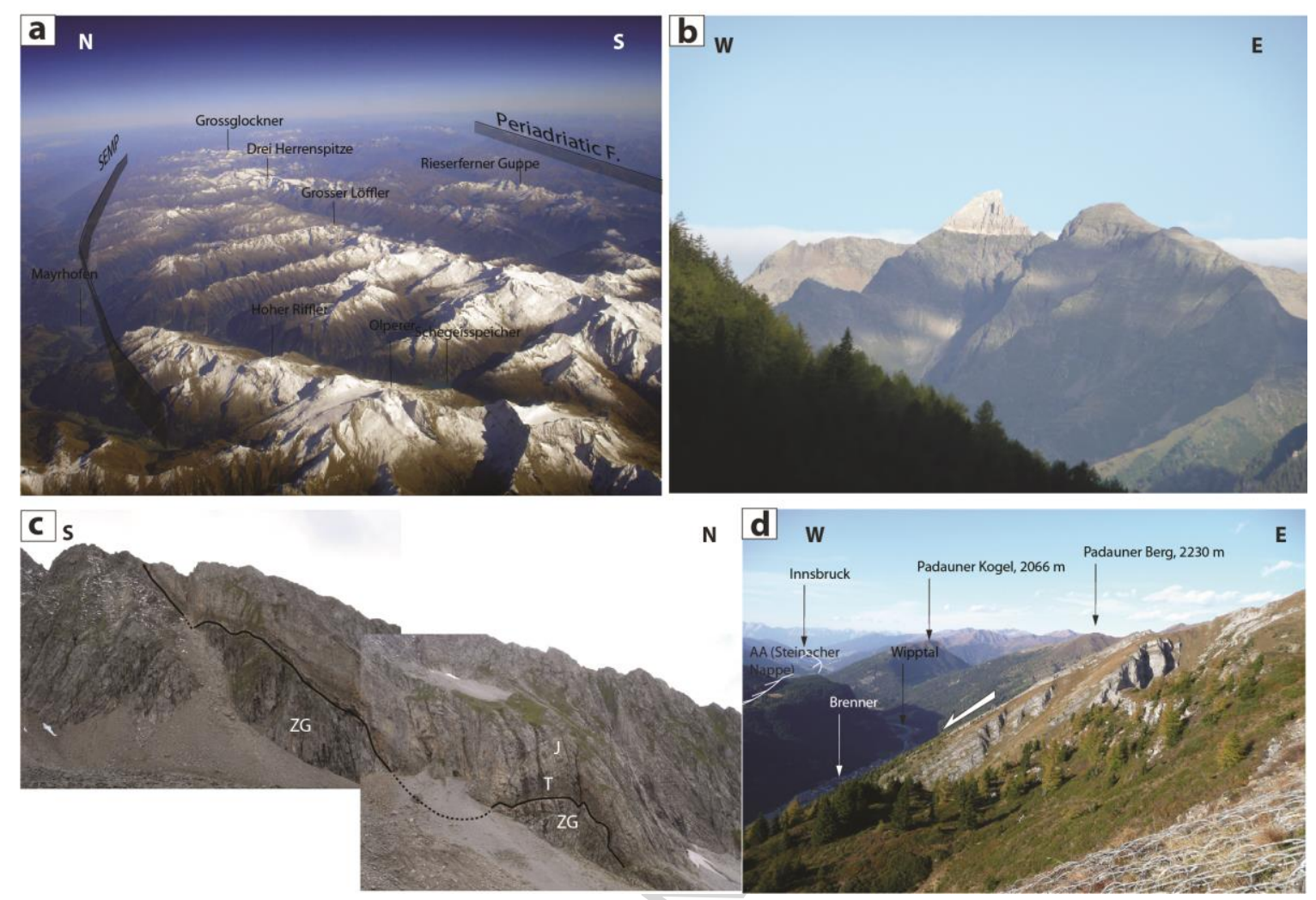

Fig. 7. Field photographs. a) Arcuate topography of the Tauern Window, reflecting the progressive transition from the ENE-striking foliations in the western sub-dome to the WNW-striking ones in the eastern sub-dome. View to the east. b) Pflersch Valley (South Tyrol/Italy). Subhorizontal Triassic Dolomites overlying the Austroalpine, Ötztal Basement, in the hangingwall of the Brenner Fault System. The flat-lying geometry of the Mesozoic cover is representative for the largely undeformed hangingwall of the Brenner Fault System. c) Upright folds in the western sub-dome of the Tauern Window. Inneres Elskar, Ziller Valley (Austria). Black line marks the folded contact of the Zentral Gneiss (Venediger Duplex) and its Mesozoic cover (above) in the northernmost limb of the dome. ZG: Zentral Gneiss; T: Triassic quartzite; J: Jurassic limestone; Fold axial planes strike ENE and dip subvertically. Dark layer above the black line is a Triassic quartzite, followed by Jurassic carbonates above. Note that the same outcrops are sketched in Sander (1911; his Fig. 2). d) Brenner Fault System; view to the north. West dipping mylonites of the Brenner Fault crop out in the frontal part of the photograph. The contact between the hangingwall (Austroalpine Steinacher nappe) and the footwall (mylonitic Matreier Zone) is marked on the western flank of the Valley (Wipp Valley) by white line. E-W striking crests in the back of the picture are the North Calcareous Alps (Austroalpine cover). 
Overprinting structural and metamorphic relationships on the outcrop and map-scales, suggest that both the upright folds, and the extensional faults along the lateral terminations of the window, represent the youngest tectonic event (Behrmann, 1988; Selverstone, 1988), following a sequence of deformation phases that started with subduction of oceanic domains. Nappe stacking first affected these oceanic units in the Late Cretaceous, and later the European basement units, in the Eo-Oligocene (Schmid et al., 2013). Several authors consider that the Oligocene dykes within the Austroalpine and Glockner nappes of the Western Tauern Window were emplaced in an already upright-folded nappe stack (Scolari \& Zirpoli, 1972; Dal Piaz et al. 1988; Bistacchi et al. 2004; Schiavo et al. 2014).

The western Tauern Window consists of large-scale, tight upright folds, folding the Venediger, Zillertal and Tuxer basement nappes (Fig. 3a) and the early Alpine S1 foliation (Selverstone, 1988; Axen et al., 1995; Bistacchi et al., 2004; 2007). These folds strike ENE, and are sub-parallel to sinistral shear zones (Figs. 2 and 3; Rosenberg and Schneider, 2008; Schneider, 2014). Overprinting relationships, point to coeval folding and sinistral shearing (Rosenberg and Schneider, 2008; Schneider, 2014), as shown by the frequent occurrence of an axial plane schistosity (S2) of upright folds consisting of sinistral mylonites (Fig. 8; Rosenberg and Schneider, 2008; Schneider, 2014).

Both sinistral shear zones and upright folds continue southwest of the Tauern Window, into Upper Austroalpine rocks (Fig. 3a; Schneider, 2014), rotating into parallelism with the western margin of the Dolomites Indenter. To the east, these structures crosscut the western Tauern sub-dome and turn into parallelism with the SEMP Fault (Fig. 3a). Therefore, a kinematic link between the western border of the Dolomites Indenter, and the sinistral SEMP Fault seems to be 
maintained across the western sub-dome of the Tauern Window (Rosenberg and Schneider, 2008; Schneider, 2014; Fig. 2). From a geodynamic perspective, this structural and kinematic continuity relates South-Alpine indentation and EastAlpine lateral extrusion along the SEMP fault.

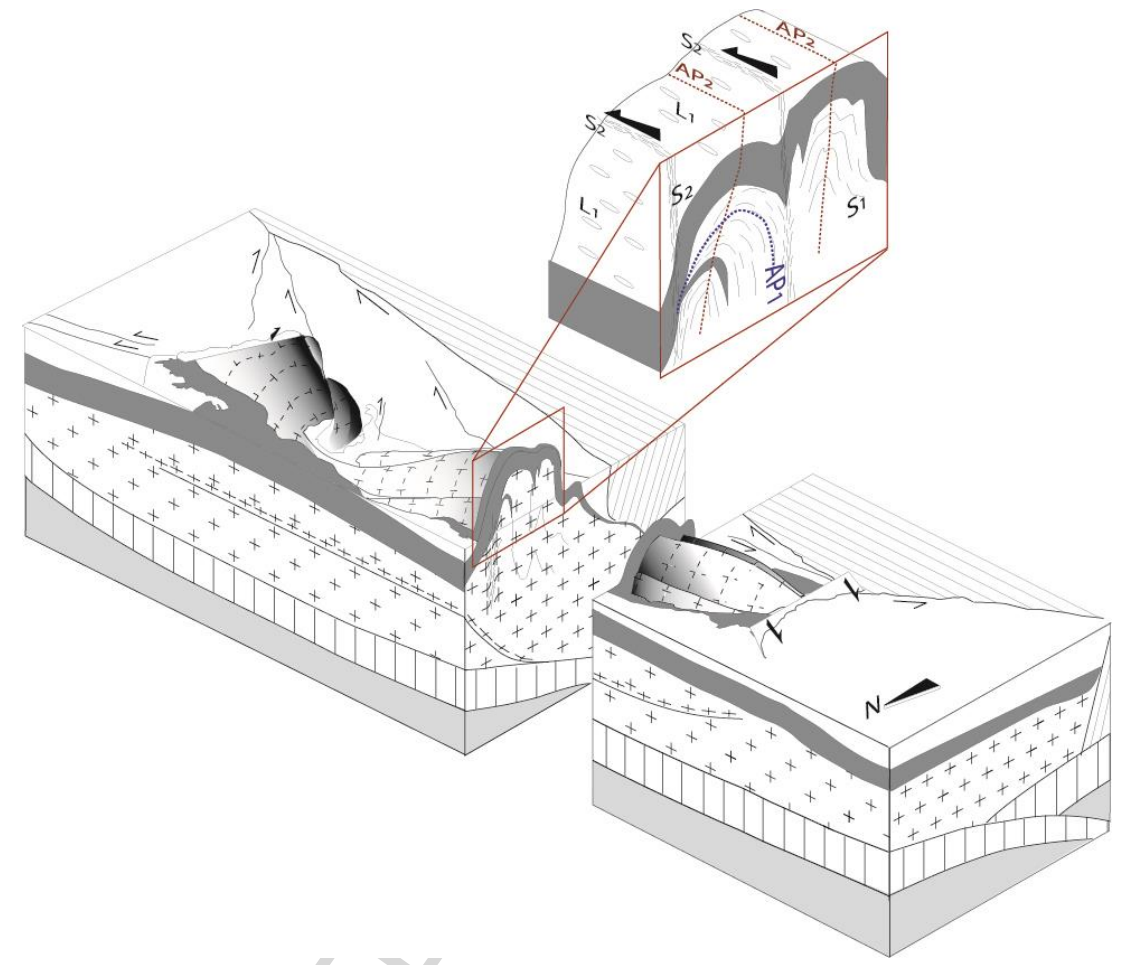

Fig. 8. Schematic block diagram, showing the relationship between the orientation of the Tauern sub-domes and faults, and the orientation (red inset) of stretching lineations, foliations, and axial planes in the western Tauern Window. AP1 represents the axial plane of the first phase of folding associated with nappe formation. AP2 represents the second phase of folding associated with doming and exhumation of the Tauern Window.

The structural grain of the eastern Tauern Window differs from that of the western Tauern sub-dome. As shown in figure 3b, the main foliation (S1) in most of the eastern sub-dome is gently dipping, and only along the southern and northern margins it steepens forming a large-scale box-type fold (Schmid et al., 2013, their cross section 8). Strike-slip shear zones and their associated mylonitic fabrics only occur along the margins of the eastern Tauern sub-dome (Fig. 3a). In contrast to the 
western Tauern sub-dome, the foliation is always a folded Early Alpine foliation (composite foliation S1 + S2 of Kurz et al., 1996), formed during nappe-stacking, and axial plane foliations associated to the upright folds are absent (Scharf et al., 2013a; Schneider, 2014).

Stretching lineations in the western Tauern sub-dome are subhorizontal and oriented ENE (Selverstone, 1988; Behrmann, 1988; Axen et al., 1995; Schneider, 2014), sub-parallel to the stretching lineations of the Brenner Mylonitic Belt and sub-parallel to the fold axes of the upright folds (Fig. 8), irrespective of the orientation of the foliation plane (Fig. 8; Schneider, 2014). Only within the central part of the Tauern Window stretching lineations are oriented north-south (Fig. 8), and inferred to be parallel to the direction of thrusting of the basement nappes, as also inferred from cut-off points of these thrust planes (Behrmann, 1990). With the exception of the areas overprinted by sinistral shear zones, the main, folded foliation, containing ENE-oriented stretching lineations in the west and north-southoriented stretching lineations in the central Tauern Window is the same foliation inferred to have formed during north-directed nappe-stacking (Fig. 8; Rosenberg and Schneider, 2008, for review). Therefore, these foliations were inferred to be reactivated and stretched parallel to the ESE-striking fold axes during upright folding, hence, doming of the Tauern Window (Schneider, 2014). Synkinematic grain growth associated with top-to-the-west sense of shear along the Brenner Fault, indicates that ductile, extensional deformation initiated before the attainment of the peak of metamorphism (Selverstone and Spear, 1985; Selverstone, 1988).

In the eastern Tauern sub-dome stretching lineations are oriented parallel to the axis of the sub-dome only within the mylonitic belt of the Katschberg Fault and along the northern and southern margins of the sub-dome. In the central part of the 
dome north-south oriented stretching lineations are dominant (Fig. 8), and they are inferred to pre-date orogen-parallel stretching along the Katschberg Fault (Kurz et al., 1996; Scharf et al. 2013a).

Based on a series of seven cross-sections perpendicular to the main structures of the Tauern Window (Schmid et al., 2013, their figure 3), we plotted in map view and interpolated the height of a reference marker, arbitrarily chosen to be the base of the Austroalpine Steinacher nappe, thus showing iso-height contours of this marker (Fig. 9b). This construction allows us to define the hinge line of the entire dome structure, and to visualize the progressive, along-strike change of dome geometry. The ENE-striking, tight antiform of high amplitude in the west and the ESE-striking antiform of large wavelength in the east (Fig. 9b) define the two domes, described above, striking at $\sim 45^{\circ}$ to each other (Fig. 9b). The direction of metamorphic iso-T contour lines (Fig. 9a) also swings from ENE in the western subdome to ESE in the eastern sub-dome, hence, they are subparallel to the axial plane of the dome. 

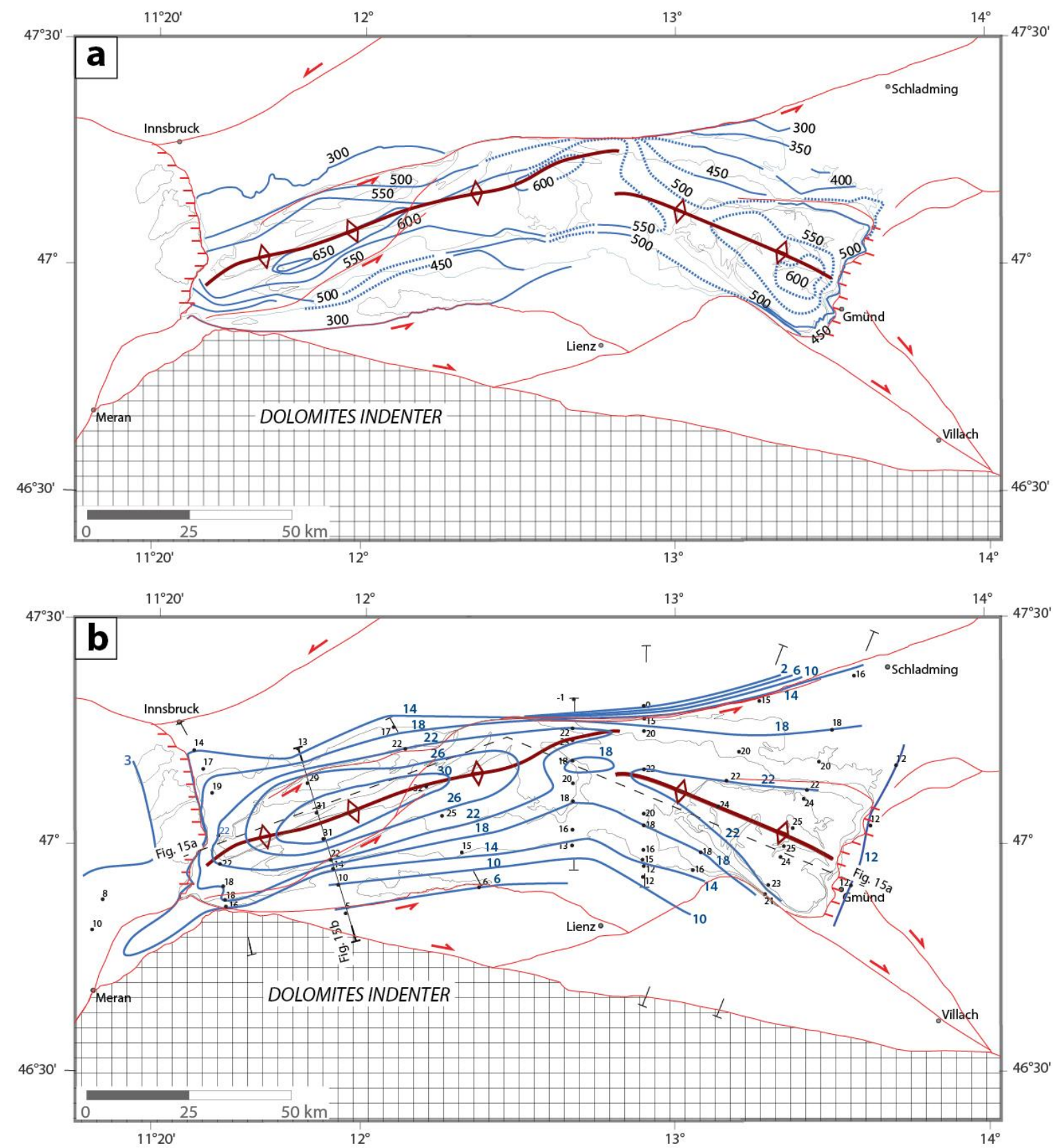

Fig. 9. Relationship between temperature distribution and dome geometry in the Tauern Window. a) Iso-temperature contours of Barrovian metamorphism in the Tauern Window. Compiled from Hörnes and Friedrichsen (1974) and Scharf et al. (2013b). Black numbers indicate metamorphic temperature. The $300^{\circ} \mathrm{C}$ iso-T contour is drawn along the inferred boundary between $\mathrm{Rb} / \mathrm{Sr}$ biotite ages reset in the Tertiary and those that have pre-Alpine ages (Borsi et al., 1978). Red lines: major Cenozoic faults. Thin black lines: major tectonic contacts and intrusive bodies. Black stippled lines: traces of sections of figure 14. Note the sub-parallel orientation of the hinge of the dome (dark red) and the Temperature contour lines. b) Inferred iso-height contours (blue lines and associated blue numbers corresponding to $\mathrm{km}$ a.s.l.) of the top of the Steinacher nappe, i.e. the structurally highest 
Austroalpine nappe exposed in the hanging-wall of the Brenner Fault System. Height points are taken from cross sections in Schmid et al. (2013), assuming nappe thicknesses as in Figure 12a. End points of cross sections from figure 4 of Schmid et al. (2013) are shown. Thick red lines correspond to the hinge of the Tauern Dome defined on the base of the blue contour lines. Black numbers indicate the reconstructed elevation of the top Austroalpine in $\mathrm{km}$ a.s.l.

The northern limb of the Tauern Dome continues down to $\sim 12 \mathrm{~km} \mathrm{depth}$, where it is thrust above the south-dipping European basement (Figs. 4 and 6; Prey, 1980; Lammerer and Weger, 1998; Schmid et al., 2004; Ortner et al., 2006; Lammerer et al., 2008, 2011). Within a horizontal distance of only $\sim 10 \mathrm{~km}$ the top of the European Basement climbs from $12 \mathrm{~km}$ depth north of the SEMP Fault (Fig. 6) to $10-15 \mathrm{~km}$ above sea-level south of the SEMP Fault (Fig. 6), where it attains the hinge of the Tauern Dome (Fig. 6). This change of structural level along the northern boundary of the European antiformal stack (the SEMP Fault), points to the existence of an orogen-scale shear zone that accommodated south-side-up displacements. In spite of differences in the geometries depicted in cross sections performed by different authors, all interpretations show this large differential uplift of the top of the European basement at the northern margin of the Tauern Window, due to thickening of the nappe stack below the window (Fig. 4; Hawkesworth et al., 1975; Prey, 1980; Lammerer, 1988; Polino et al., 1990; Schmid et al., 2004, 2013; Lammerer et al., 2011). Part of this south-side-up displacement coincides with the Ahorn Shear Zone (Fig. 3a; Cole et al., 2007; Rosenberg and Schneider, 2008), a 50 $\mathrm{km}$ long and $2 \mathrm{~km}$ thick sinistral shear zone, in which south-side-up kinematic indicators were described. Even though the outcrop-scale structures show that stretching lineations along the northern limit of the Tauern Window are subhorizontal (Cole et al., 2007; Rosenberg and Schneider, 2008; Schneider, 2014), a 
remarkable, vertical displacement was accommodated along this area, as testified by the steep gradients of metamorphism (Fig. 9a) and of cooling ages (Fig. 5), in addition to cross-sectional evidence. This discrepancy between vertical displacement and orientation of the X-axis of the finite deformation ellipsoid is common in transpressional shear zones (Tikoff and Teyssier, 1994).

Along-strike changes in the amplitude of the Tauern dome are the expression of an overall eastward decrease of north-south shortening (Schmid et al., 2013; Rosenberg et al., 2015; Bertrand et al., 2017). In spite of many simplifications and assumptions, first attempts to quantify such amounts of shortening indicate that the eastern sub-dome is affected only by about half of the shortening that was accommodated in the western sub-dome, and even less in the central part of Tauern Window (Schmid et al., 2013; Rosenberg et al., 2015). Balancing the line-length of the base of the Austroalpine units along several cross sections, points to an alongstrike change in the amount of shortening accommodated by the sub-domes from $\sim 60 \mathrm{~km}$ in the west to $38 \mathrm{~km}$ in the east of the Tauern Window (Rosenberg et al., 2015), if the antiformal structure is inferred to affect all units down to the top of the "undeformed" European basement, i.e., down to 30 km depth (Figs. 4; 6a; e.g., Polino et al. 1990; Schmid et al., 2004; Castellarin et al 2006). Previous estimates of shortening, performed in the same way, but calculating the line length down to 5 or $10 \mathrm{~km}$ below the sea level only, are smaller (31-32 km for the western sub-dome and less for the eastern sub-dome; Schmid et al., 2013).

\section{II.4. Alpine metamorphism}

The Alpine metamorphic history of the Tauern Window started with an Early Cenozoic high-pressure event, well recorded within a thin sliver of high-pressure 
rocks located at the top of the European basement nappes (Bianchi, 1934; Dal Piaz (1934; Oberhänsli et al., 2004), in the lower portion of the Matreier Zone (LiguroPiemont-derived Unit; Figs. 2 and 3a) and in some parts of the Glockner nappes (see Schmid et al., 2013). The age of high-pressure metamorphism is inferred to be 44-37 Ma based on different ${ }^{40} \mathrm{Ar} /{ }^{39} \mathrm{Ar}$ plateau ages of (1) high-Si phengites in phyllites and cherts with abundant high Si-phengites (44-37 Ma, Dingeldey et al., 1997) from the Reckner and Hippold nappes, of (2) high-pressure Na-amphibole and phengite (42-39 Ma, Ratschbacher et al., 2004) from the Eclogite Zone, and of (3) phengites (39-38 Ma, Kurz et al., 2008) from the Eclogite Zone and the Modereck Nappe. Slightly younger high-pressure ages, comprised between 36 and $32 \mathrm{Ma}$, were obtained by Zimmermann et al. (1994), by dating amphiboles and phengites from several Penninic units, also by Ar-Ar step heating experiments. Recent studies document instead a distinct, younger and shorter time interval of HP metamorphism in the Eclogite Zone, that is constrained in the 32-33 Ma time lapse based on: (1) the multimineral $\mathrm{Rb} / \mathrm{Sr}$ internal isochron approach (Glodny et al., 2005) and by (2) a Lu-Hf isochron of garnet (Nagel et al., 2013).

A Barrovian, high-temperature metamorphic event (Sander, 1911, Bianchi 1934, Morteani, 1974, Morteani and Raase, 1974) overprinted the high-pressure assemblages (Hawkesworth et al., 1975; De Vecchi and Baggio, 1982; De Vecchi, 1989) as also shown by the iso-T contours of Barrovian metamorphism crosscutting the major nappe contacts inferred to have formed under HP conditions in the Tauern Window (e.g., Droop, 1985; Fig. 9a). Peak-metamorphic temperatures attained $650{ }^{\circ} \mathrm{C}$ in the western Tauern Window (Hörnes and Friedrichsen, 1974) at pressures of $\sim 0.7 \mathrm{GPa}$ (Selverstone, 1993), and $620{ }^{\circ} \mathrm{C}$ in the eastern Tauern Window (Scharf et al., 2013b). Several studies extrapolated in map view the 
temperature estimates associated with the Barrovian metamorphic event into continuous iso-T lines (Hoernes and Friedrichsen, 1974; De Vecchi and Baggio, 1982; Frey et al., 1999; Bousquet et al., 2012; Scharf et al., 2013b). In spite of local offsets inferred to displace these T- contour lines along sinistral shear zones in the Tauern Window (De Vecchi and Baggio, 1982), most authors agree that the Tcontour lines show a regular pattern, sub-parallel to the long axis of the window and discordant with respect to the major nappe contacts (Fig. 9a), indicating that hightemperature metamorphism took place after emplacement of the nappes (Droop, 1985; Selverstone, 1985; Genser et al., 1996; Bousquet et al., 2008). Metamorphic temperatures are higher in the axial zone of the Tauern Window and decrease outwards in an elongate concentric fashion (Fig. 9a), suggesting that both the structures and the distribution of metamorphic temperatures reflect the geometry of an elongate dome.

The peak-metamorphic temperature in the Tauern Window is often inferred to be identical with a recrystallization event temed 'Tauernkristallisation' by Sander (1911). A compilation of age data and their interpretations in terms of dating the peak of Barrow metamorphism is shown in Table I. Before discussing these data, it should be noted that in a context of exhumation dominated by folding and erosion, uplift and exhumation rates are higher in the hinge of an antiformal structure and decrease towards the limbs. This leads to younger cooling ages in the hinge region of such structures, as illustrated and discussed in the next section and in thermomechanical models (e.g., Batt and Braun, 2007). As a consequence, assuming that the peak of metamorphism lasted several million years, samples from the hinge region of the Tauern Dome will have younger cooling ages than samples from the rims. In addition, Cliff et al. (1985) pointed out that younger cooling ages derived 
from lower structural levels may be related to a delay in the attainment of the $\mathrm{T}$ peak in lower structural levels, as predicted from thermal models (England and Thompson, 1984). Hence, the position of samples within the antiformal structure has a strong influence on the cooling age.

The large majority of the studies listed in Table I determined the T peak of metamorphism by considering it coeval or older than the age obtained from thermochronometers with closure temperatures in the range of the highest metamorphic T attained during Barrow metamorphism (Cliff et al., 1985; von Blanckenburg et al., 1989; Reddy et al., 1993; Inger and Cliff, 1994; Favaro et al., 2015; Schneider et al., 2015). Alternatively, formation ages of minerals inferred to grow until the peak of metamorphism were inferred to define its age (Christensen et al., 1994; Cliff et al., 2015). Others used cross cutting relationships between dated dykes and metamorphic fabrics (Scolari and Zirpoli, 1972). They suggested that the peak of metamorphism must be older than the 31 Ma tonalitic dykes (Mancktelow et al., 2001) that cut the high-temperature schistosity of the Glockner nappes. This age is consistent with the pre-32 Ma proposed by Favaro et al. (2015) and the 34-37 Ma proposed by Schneider et al. (2015).

\begin{tabular}{|c|c|c|c|c|}
\hline Reference & Age data & Method & Rocks and area & Inferred peak metamorphic age \\
\hline Lambert 1970 & $35 \mathrm{Ma}$ & $\begin{array}{l}\mathrm{K}-\mathrm{Ar} \text { on muscovite } \\
\text { ages between } 28-34 \mathrm{Ma}\end{array}$ & $\begin{array}{l}\text { Greenschist facies } \\
\text { rocks, E-central TW }\end{array}$ & \\
\hline Cliff et al., 1985 & $\begin{array}{l}23.8 \mathrm{Ma} \\
17.5-22.5 \mathrm{Ma}\end{array}$ & $\begin{array}{l}\text { Ar/Ar on amphibole } \\
\text { K/Ar white mica }\end{array}$ & $\begin{array}{l}\text { Zentralgneiss, } \\
\text { Hochalmdome }\end{array}$ & $\begin{array}{l}\text { - } 35 \text { Ma at higher structural levels } \\
\text { (Hawkesworth et al., 1975) } \\
\text { - } 25 \text { Ma at deeper structural levels } \\
\text { (own age data) }\end{array}$ \\
\hline $\begin{array}{l}\text { von Blanckenburg, } \\
1989\end{array}$ & $20 \mathrm{Ma}$ & $\mathrm{Rb} / \mathrm{Sr}$ on phengite & Western TW & $\begin{array}{l}20 \mathrm{Ma} \text {, defined by isotopic } \\
\text { system with highest closure } \mathrm{T}\end{array}$ \\
\hline Reddy et al., 1993 & $82-24 \mathrm{Ma}$ & $\mathrm{Rb} / \mathrm{Sr}$ on white mica & Sonnblick Dome & $\begin{array}{l}27 \text { Ma corresponding to age } \\
\text { clusters of rocks inferred to be } \\
\text { more strongly recrystallized }\end{array}$ \\
\hline $\begin{array}{l}\text { Christensen et al., } \\
1994\end{array}$ & $30 \mathrm{Ma}$ & $\mathrm{Rb} / \mathrm{Sr}$ on garnet & $\begin{array}{l}\text { Western TW, } \\
\text { Pfitscher Joch area }\end{array}$ & $\begin{array}{l}30 \mathrm{Ma} \text { is the age of garnet rims } \\
\text { inferred to terminate growth due } \\
\text { to onset of cooling. }\end{array}$ \\
\hline Inger and Cliff, 1994 & 37-22 Ma & Rb-Sr white mica & $\begin{array}{l}\text { Eclogite Zone } \\
(30-26 \mathrm{Ma}) \\
\text { SE TW (31-22 Ma) }\end{array}$ & $\begin{array}{l}\text { Clustering of data at } 30- \\
28 \text { Ma inferred to represent } \\
\text { peak conditions }\end{array}$ \\
\hline
\end{tabular}




\begin{tabular}{|c|c|c|c|c|}
\hline Thöni, 1999 & $\begin{array}{l}\text { Review, no } \\
\text { new data }\end{array}$ & & & $\begin{array}{l}\text { - } 35 \mathrm{Ma} \text { at higher structural levels } \\
\text { - } 25 \mathrm{Ma} \text { at deeper structural levels, } \\
\text { based on Cliff et al. (1995) }\end{array}$ \\
\hline $\begin{array}{l}\text { Pollington and } \\
\text { Baxter, } 2010\end{array}$ & $\begin{array}{l}28 \mathrm{Ma} \text { (core) } \\
20 \mathrm{Ma} \text { (rim) }\end{array}$ & $\mathrm{Sm} / \mathrm{Nd}$ on garnet & Western TW & $\begin{array}{l}\text { No interpretation in terms of meta- } \\
\text { morphic peak }\end{array}$ \\
\hline Favaro et al., 2015 & $\begin{array}{l}\text { Review, no } \\
\text { new data }\end{array}$ & $\mathrm{Rb} / \mathrm{Sr}$ on white mica & $\begin{array}{l}\text { Review of data } \\
\text { from eastern and } \\
\text { western TW }\end{array}$ & $\begin{array}{l}\text { Cooling ages of Reddy et al. (1993) } \\
\text { and Satir (1975) from areas where } \\
\text { T-max exceeded } 500-550^{\circ} \mathrm{C} \text { are } \\
\text { inferred to post-date peak of } \\
\text { metamorphism, which is therefore } \\
\text { post } 32 \mathrm{Ma} \text {. }\end{array}$ \\
\hline Cliff et al., 2015 & $28 \mathrm{Ma}$ & ${ }^{232} \mathrm{Th}-208 \mathrm{~Pb}$ on allanite & & $\begin{array}{l}28 \text { Ma porphyroblasts overgrow } \\
\text { folded fabric inferred to be pre- or } \\
\text { syn-peak metamorphism. Thus peak } \\
28 \mathrm{Ma}\end{array}$ \\
\hline $\begin{array}{l}\text { Schneider et al., } \\
2015\end{array}$ & $36-25 \mathrm{Ma}$ & $\mathrm{U}-\mathrm{Pb}$ on allanite & $\begin{array}{l}\text { Zentralgneiss, } \\
\text { western TW }\end{array}$ & $\begin{array}{l}\text { 37-34 Ma by linear extrapolation of } \\
\text { age vs T data from } 600 \text { to } 450^{\circ} \mathrm{C}\end{array}$ \\
\hline
\end{tabular}

Table I: Compiled, inferred ages of Barrovian metamorphic peak in the Tauern Window.

Figure 9a shows the interpolation of compiled temperature data in the form of T-contour lines. In the western sub-dome, temperatures are derived from oxygen isotopic ratios (Hörnes and Friedrichsen, 1974), and in the eastern sub-dome from the crystalline structure of carbonaceous material measured by Raman spectroscopy (Scharf et al., 2013b) and from the distribution of metamorphic minerals (Bousquet et al., 2012). In addition the $300^{\circ} \mathrm{C}$ iso-T contour line is shown, defined as the boundary between Cenozoic reset and un-reset biotite $\mathrm{Rb} / \mathrm{Sr}$ ages.

In the eastern sub-dome, the Raman-derived temperatures are in good agreement with those previously constructed based on the occurrence of hightemperature metamorphic minerals (Höck, 1980; Bousquet et al, 2012), inferred to result from Barrovian metamorphism (Bousquet et al., 2008). The tendency for slightly higher Raman-derived temperature is consistent with the idea that this method records the peak temperature attained by rocks throughout its metamorphic history. It was suggested (Scharf et al., 2013b) that the T-contours derived from Raman spectroscopy result from the temperature distribution associated to different geodynamic processes, as subduction and collision, hence, 
from different ages (Late Cretaceous to Oligocene). However, based on the continuity of the T-contour-pattern, its discordance to the nappe boundaries, and its sub-parallelism to the dome geometry (Fig. 9a), we do suggest that they largely reflect the (Barrovian) collisional metamorphism, as inferred for the western subdome. The distributed temperature gradient observed along the north-eastern limb of the dome $\left(200{ }^{\circ} \mathrm{C}\right.$ over a distance of $25 \mathrm{~km}$ in map view, Fig. 9a; Scharf et al., $2013 \mathrm{~b})$ compared to the sharp gradient of the southeastern limb $\left(200^{\circ} \mathrm{C}\right.$ within less than $5 \mathrm{~km}$ in map view) is also consistent with the asymmetry of the Tauern antiform, which is steeper in the south (Fig. 6).

Temperature contours strike sub-parallel to the axial-plane of the Tauern Dome (Fig. 9a), hence, they are oriented ENE in the western sub-dome and ESE in the eastern sub-dome. Temperatures decrease systematically from the axial zone of the Window to the northern and southern boundaries, and the contour lines of the highest $\mathrm{T}$ almost coincide with the trace of the Dome hinge (Fig. 9a), where they attain a maximum of $650{ }^{\circ} \mathrm{C}$ in the west (Oxygen isotope determinations; Hoernes and Friedrichsen, 1974) and $620{ }^{\circ} \mathrm{C}$ in the east (Raman spectroscopy of carbonaceous material; Scharf et al., 2013b).

The iso-T contours of the western sub-dome appear to be truncated by the Brenner Mylonites (Fig. 9a). At the eastern termination of the dome the truncation is less abrupt, and a rotation of $\sim 90^{\circ}$, brings the iso-T contours into parallelism with the Katschberg Fault in the area overprinted by the Katschberg Mylonites (Fig. 9a). These observations suggest that orogen-parallel extension affected the pattern of iso-T contours, hence, the thermal structure of the dome, only within the cataclastic and mylonitic zones of the normal faults located at both margins of the dome. 
Therefore, these mylonitic zones may be synchronous to-, or late, with respect to high-temperature metamorphism.

Little is known about the spatial distribution of pressures associated with the peak of Barrovian metamorphism. Based on quantitative modelling of zoned garnets and on garnet-plagioclase-kyanite-quartz geobarometry, on samples from the postVariscan cover in the Venediger Duplex (Lower Schieferhülle of the Western Tauern Window following the nomenclature of Selverstone et al., 1984), pressures of 0.7 GPa were inferred to correspond to rim equilibration of the grains at high temperature (Selverstone et al., 1984). In the eastern sub-dome $0.76 \mathrm{GPa}$ (Cliff et al., 1985; Droop, 1985). Hoinkes et al. (1999), based on a review of literature data suggested a pressure of $0.5-0.7 \mathrm{GPa}$, whereas Bousquet et al. (2008) proposed 0.5 GPa. Summarizing, we may conclude that $\sim 20 \mathrm{~km}$ of crust have been eliminated from the axial zone of the Tauern Window since the "Tauernkristallisation" (Sander, 1911), i.e., since the peak of high-temperature metamorphism. This value is in close agreement with the difference in elevation existing between structural markers (as nappe contacts) located north of the Tauern Window and in the hinge of the Tauern Window.

South of the western sub-dome the Austroalpine units are overprinted by Oligo-Miocene greenschist-facies metamorphism (Fig. 2), as indicated by Cenozoic cooling ages of $\mathrm{Rb} / \mathrm{Sr}$ isochrons of mainly whole rock-biotite (Borsi et al., 1978). Such unusually young ages of the Austroalpine basement are not spatially related to the Periadriatic plutons and are corroborated by zircon fission track ages, also being younger than in the remaining Austroalpine of the Eastern Alps (Fig. 5a). This area represents an exception in the entire Alpine chain, in which the Austroalpine is otherwise considered as an orogenic lid (Laubscher, 1983) that behaved in a brittle 
manner throughout collision. From a structural point of view, this part of the Austroalpine and its southwestern continuation into the Meran-Mauls Block (Fig. 3a) is quite unique, in that it is characterized by upright, tight and partly overturned folds, that strike parallel to the upright folds of the Tauern Window. In contrast, north of the Tauern Window, the Austroalpine forms a gently, northward dipping structure (Fig. 6c) that is not affected by post-Cretaceous metamorphism. Therefore, the overturned orientation of the southern limb of the dome, which brought a thick column of Glockner nappes units to rest above the Austroalpine nappes (Fig. 6c), probably explains its metamorphic temperature. Nowhere else in the Eastern Alps, the Austroalpine basement units were affected by such an intense shortening during collision.

\section{The Brenner Fault}

The Brenner Fault strikes across Upper Austroalpine units all along its hanging wall, whereas it crosses the entire nappe stack in the footwall, passing, from south to north, from Upper Austroalpine nappes, to the Matreier Zone, to the Glockner nappes and finally to the European basement nappes (Figs. 2, 3). This deepest part of the exposed collisional wedge is attained in the area of the Brenner Pass (Fig. 3a) and from there northward, the mylonitic belt climbs back upward through the nappe stack, again passing across the Glockner nappes, the Matreier Zone, and finally attaining the Upper Austroalpine nappes at the northwestern margin of the Tauern Window (Fig. 3). Metamorphic pressure in the footwall was inferred to have been $0.8 \mathrm{GPa}(\sim 25 \mathrm{~km})$ during the Oligocene (Selverstone, 1995), whereas the hanging-wall was inferred to have attained only 4-5 km depth at the 
same time (Fügenschuh et al., 1997), based on apatite fission track ages. The reconstructed tectono-stratigraphy of the footwall and hanging-wall shows that the vertical offset between them corresponds to a maximum of $17 \mathrm{~km}$ (Schmid et al., 2013) in the area coinciding with the hinge of the Tauern Dome.

Against the opinion that the Brenner Fault is a "textbook example of a normal fault" (Fügenschuh et al., 2012), we consider it a very peculiar structure, sharing several, but not all classical features of normal faults. The trace of the fault at the surface is not only the boundary between footwall and hanging-wall of a normal fault, but also the boundary between an area that is severely shortened during collision (east of the Brenner Fault, Fig. 7c) and one that was almost unaffected by collisional shortening, still exhibiting the gentle dip of unfolded Cretaceous nappes (hangingwall west of the Fault; Fig. 7b). Hence, the Brenner Fault represents the boundary, which decoupled two adjacent parts of the collisional wedge, allowing one of them (in front of the indenter) to shorten and one (west of the indenter) to remain nearly undeformed. The reason for such a dramatic, differential shortening stems from the geometry of the Dolomites Indenter, whose corner is located at the southern termination of the Brenner Fault (Figs. 2 and 3a). West of this corner the indenter displacement was essentially accommodated along a sinistral strike-slip fault (Giudicarie Fault System; Fig. 2), whereas east of the indenter's corner it was mainly accommodated by north-south shortening that gave rise to the antiformal structure of the Tauern Window, and by conjugate strike slip faults that allowed for lateral extrusion (Ratschbacher et al., 1991b).

The Brenner Fault consists of a thick, up to $1.5 \mathrm{~km}$, mylonitic belt (Brenner Mylonites), striking from Sterzing to Steinach (Fig. 3a), and of a cataclastic zone, located in the northward, along-strike continuation of the mylonitic belt. The latter 
is termed the Silltal Fault (Fügenschuh et al., 1997). In addition, east of the Brenner Fault, over a distance of $\sim 20 \mathrm{~km}$, the footwall is dissected by a series of high-angle, west-dipping normal faults also showing a component of sinistral displacement (Baggio and De Vecchi, 1982; Schiavo et al., 2014). The transition from the Brenner Mylonites to the Silltal cataclasites probably represents the exhumed, Miocene brittle-ductile transition of the Brenner Fault. Upright folding tilted this originally sub-horizontal transition, now exposing its deeper and ductile part within the Tauern Window.

The along-strike transition of the Brenner Mylonites to progressively higher structural units when moving from the Brenner Pass both towards the south and the north (Fig. 3a) may be explained in three different ways: 1) by considering that the Brenner Mylonites formed after, or late with respect to folding (Rosenberg and Garcia, 2011), as also suggested by the net truncation of the footwall iso-T contours by the Brenner Mylonites (Fig. 9a). In this case, exhumation, or at least its largest part, must have occurred before extension, in order to uplift and exhume the deepest European units at the same structural level of the Austroalpine ones, that are now exposed at the southern and northern margins of the Brenner Fault; 2) extensional mylonites may have formed at the same time as the upright Tauern fold (Rosenberg and Garcia, 2012; Schmid et al., 2013). In this case, new top-to-the-West extensional mylonites need to form continuously after folding of the older ones in order to explain how the Brenner Mylonites reach progressively deeper structural units towards the hinge of the Tauern Dome. This process is schematically depicted in figure 10, showing how the formation of new mylonites goes together with the deactivation of the folded ones that become included into the hanging-wall. Similarly, new mylonites form, overprinting rocks that were previously part of the 
footwall, below the mylonitic zone. Therefore, particle paths oblique to- and cross cutting the mylonitic zone displace parts of the footwall through the extensional shear zone, hence, into the hanging-wall. These particle paths, driven by amplification of the antiform contribute to exhumation by folding and erosion. A similar model was first proposed for the Simplon Fault (Mancktelow and Pavlis, 1994), however in an area of synformal, not antiformal folding. 3). An along-strike decrease of fault-parallel displacements from the Brenner Pass towards both the south and the north could explain why the Brenner Mylonites affect progressively higher crustal levels, suggesting decreasing amounts of extensional unroofing. In this case the amounts of displacement within the fault plane, should vary by tens of $\mathrm{km}$. If such displacement differences were to occur, they would be accommodated by numerous strike-slip shear zones striking parallel to the extensional direction, and showing dextral shear sense south of the Brenner Pass and sinistral to the north. However, shear zones are predominantly sinistral south of the Brenner Pass (Rosenberg and Schneider, 2008; Schneider, 2014; Fig. 3a), and they largely disappear to the north. In summary, model 1) is not consistent with the inferred coeval age of folding and extension, based on both structural and geochronological arguments. Model 3) is not consistent with the structural evidence, leaving model 2) as the most plausible. However, a late onset of extension with respect to folding, but still coeval with the latter process, would also be consistent with all observations. 


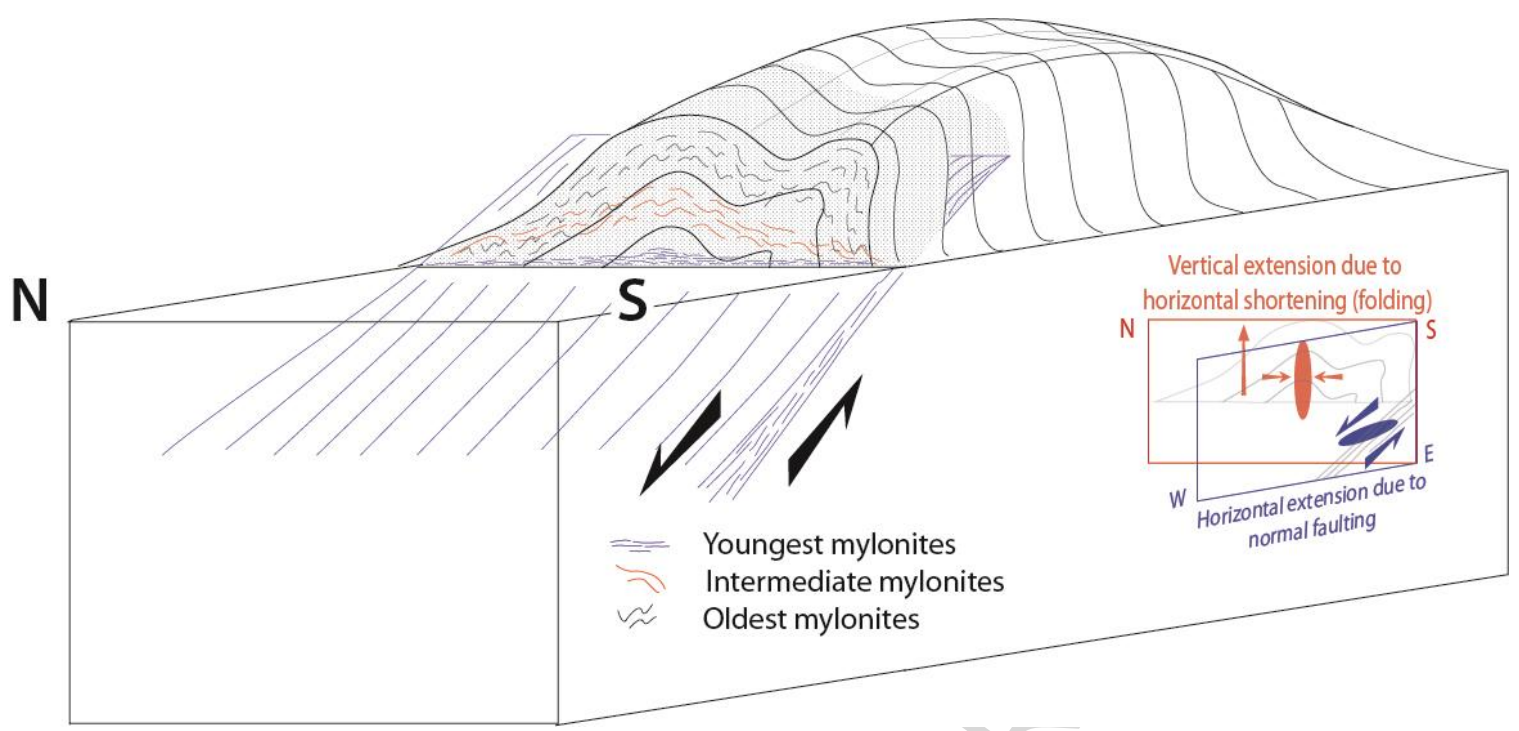

Fig. 10. Block diagram showing the geometrical evolution of a mylonitic belt that is undergoing shortening by folding contemporaneous to extension by normal shearing. Folded mylonites are deactivated and cut by newly formed mylonites that continue to accommodate E-W extension, before they become folded themselves and cut by new mylonites. Inlet shows schematically a vertical component of extension accommodated by $\mathrm{N}$-S folding and a subhorizonatal component accommodated by low-angle, top-to-the West extension. Dotted volume corresponds to the hangingwall of the youngest mylonites and includes older, folded mylonites.

A major source of ambiguity in the debate on exhumation mechanisms of the Tauern Window rests on the difficulty of constructing reliable cross sections striking perpendicular to the Tauern Window, in the footwall of the Brenner Fault. The upward projection of footwall structures located within the plane of the section results in an antiformal structure of high amplitude, affecting the entire nappe stack, and pointing to an eroded rock column being 10-15 km thicker than that of the hanging-wall (Fig. 11a, Rosenberg and Garcia, 2011; Schmid et al., 2013). On the other hand, the upward projection of surface structures from the hanging-wall (Fig. 11b; Schmid et al., 2013), located west of the plane of the sections results in the truncation of all structures by the low-angle Brenner Fault, at a level of only 4-5 km above the surface (Fig. 11b, Schmid et al., 2013), hence not showing the upper part 
of the antiformal footwall structure. In the first case denudation must have occurred mainly by erosion, in the second case by extension. Because the Brenner Fault coincides with the boundary between a western, barely shortened area, and an eastern, severely shortened area, the lateral projection of structures from one area to the other, which always assumes a structural continuity, is questionable. However, both sections of Figure 11 (Schmid et al., 2013) indicate that the entire Glockner nappes and Austroalpine nappes in the southernmost antiform of the section are eroded, almost exhuming the European basement, in the absence of an extensional structure. Therefore, folding and erosion there cause the exposure of the European basement, or at least its Mesozoic cover, irrespective of the differences in the construction of the section.

\section{a}
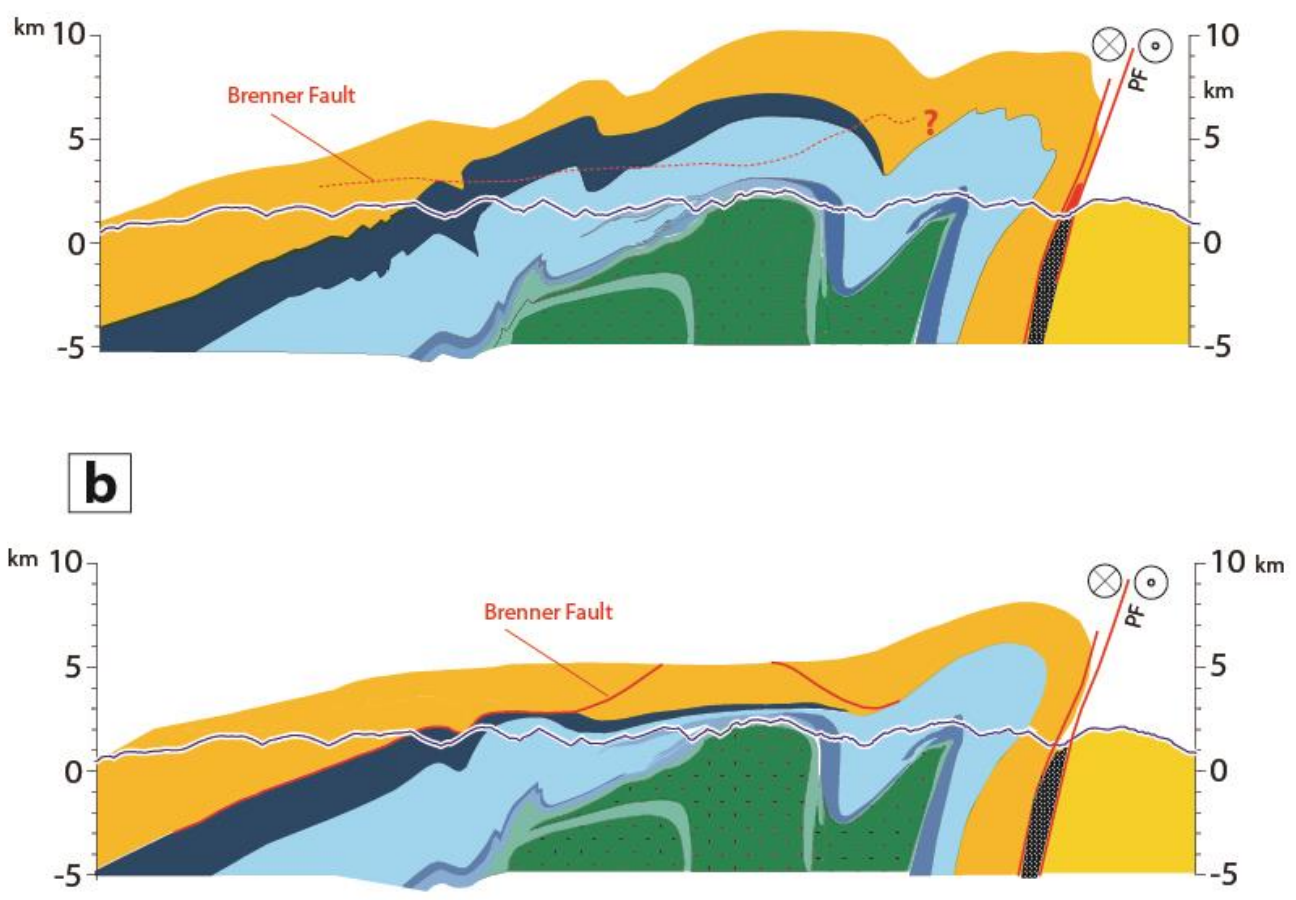

\begin{tabular}{|c|c|c|c|c|}
\hline $\begin{array}{l}\text { European } \\
\text { cover }\end{array}$ & $\begin{array}{l}\text { Valais-derived } \\
\text { nappes }\end{array}$ & Austroalpine & $\begin{array}{l}\text { Modereck } \\
\text { nappe }\end{array}$ & $\begin{array}{l}\text { Periadriatic } \\
\text { plutons }\end{array}$ \\
\hline $\begin{array}{l}\text { European } \\
\text { basement }\end{array}$ & $\begin{array}{l}\text { Liguro-Piemont } \\
\text {-derived nappes }\end{array}$ & $\begin{array}{l}\text { South-Alpine } \\
\text { basement }\end{array}$ & $\begin{array}{l}\text { Wolfendorn } \\
\text { nappe }\end{array}$ & Major faults \\
\hline
\end{tabular}


Fig. 11. N-S-oriented cross-sections located immediately east of the Brenner Fault. Traces of sections are shown by stippled, black line in figure 3a. a) Construction assuming folding and erosion of Brenner mylonites as in figure 10; b) Construction assuming projecting the geometry of the Brenner Mylonites as constrained in their area of exposure west of the cross section. PF: Periadriatic Fault. Modified from Schmid et al. (2013).

\section{The Katschberg Fault}

$S$

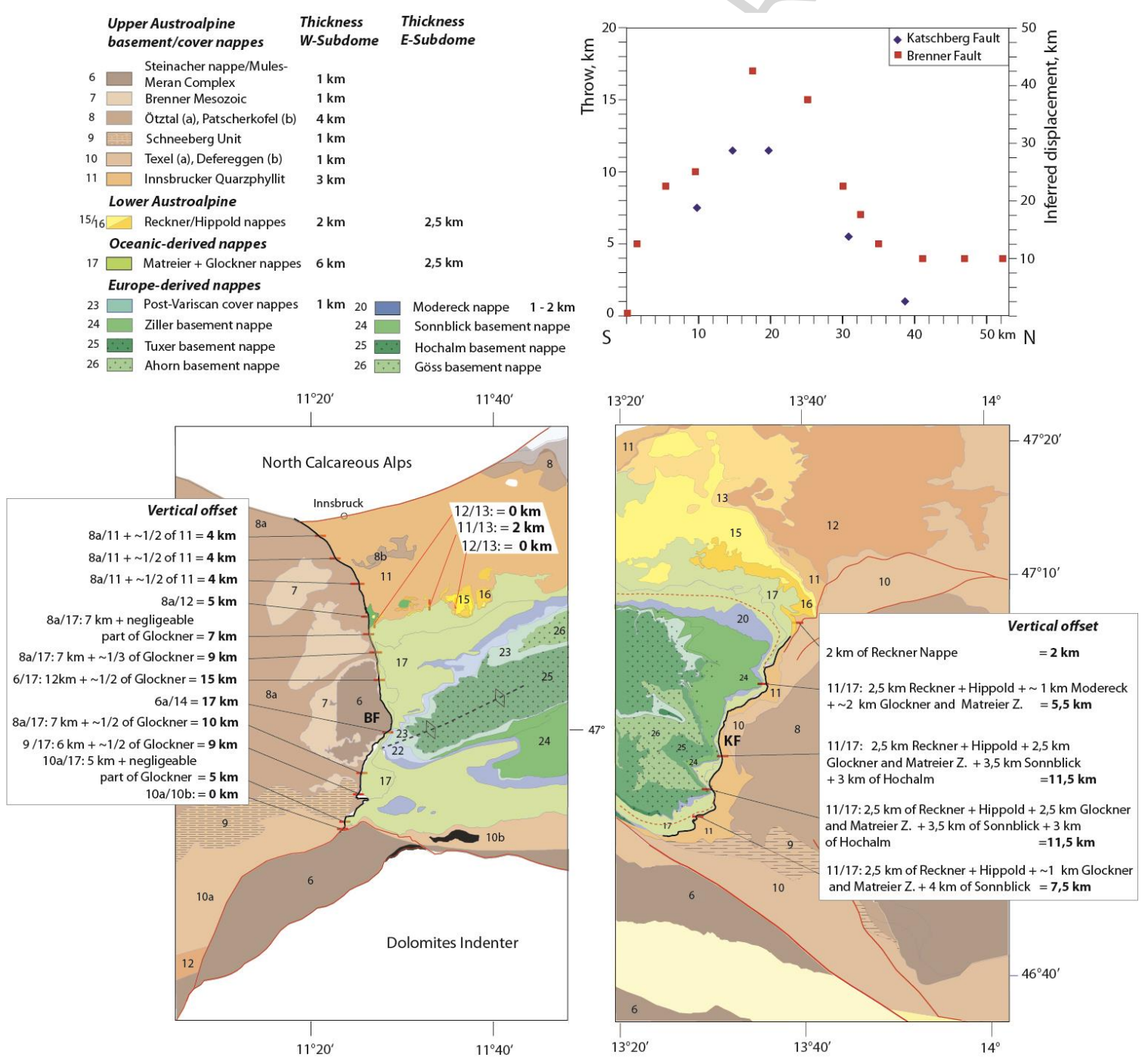

Fig. 12. Tectonic maps modified after Schmid et al. (2013) showing the change of vertical offset ("stratigraphic omission") along the Brenner and Katschberg faults. Diagram in the upper right part of the picture shows distance along-strike of the Brenner and Katschberg 
faults vs throw/displacement. Note the increase in stratigraphic omission towards the hinge of the antiform. Numbers separated by slash in the insets refer to the numbers shown in the legend of the tectonic units. They indicate which nappes are set in direct contact by the Brenner and Katschberg faults, hence allowing to calculate the omitted nappe thickness, which is shown by bold numbers, also in the insets. These values are plotted in the distance vs throw diagram.

The Katschberg Fault (Genser and Neubauer, 1989; Figs. 2, 3a) consists of an up to $5 \mathrm{~km}$ thick belt of mylonites, which underwent retrograde amphibolitic- to greenschist-facies metamorphism, during top-to-the-East to Southeast normal shearing (Scharf et al., 2013a). Only the central part of this NNE-striking belt is capped by cataclasites at the base of its hanging-wall (Scharf et al., 2013a), and the entire belt of mylonites that wrap around the eastern sub-dome were termed Katschberg Shear Zone System (KSZS; Scharf et al., 2013a). These top-to-the East to Southeast mylonites terminate, and are in kinematic continuity with dextral and sinistral shear zones at the northern and southern ends of the KSZS, respectively (Scharf et al., 2013a). 


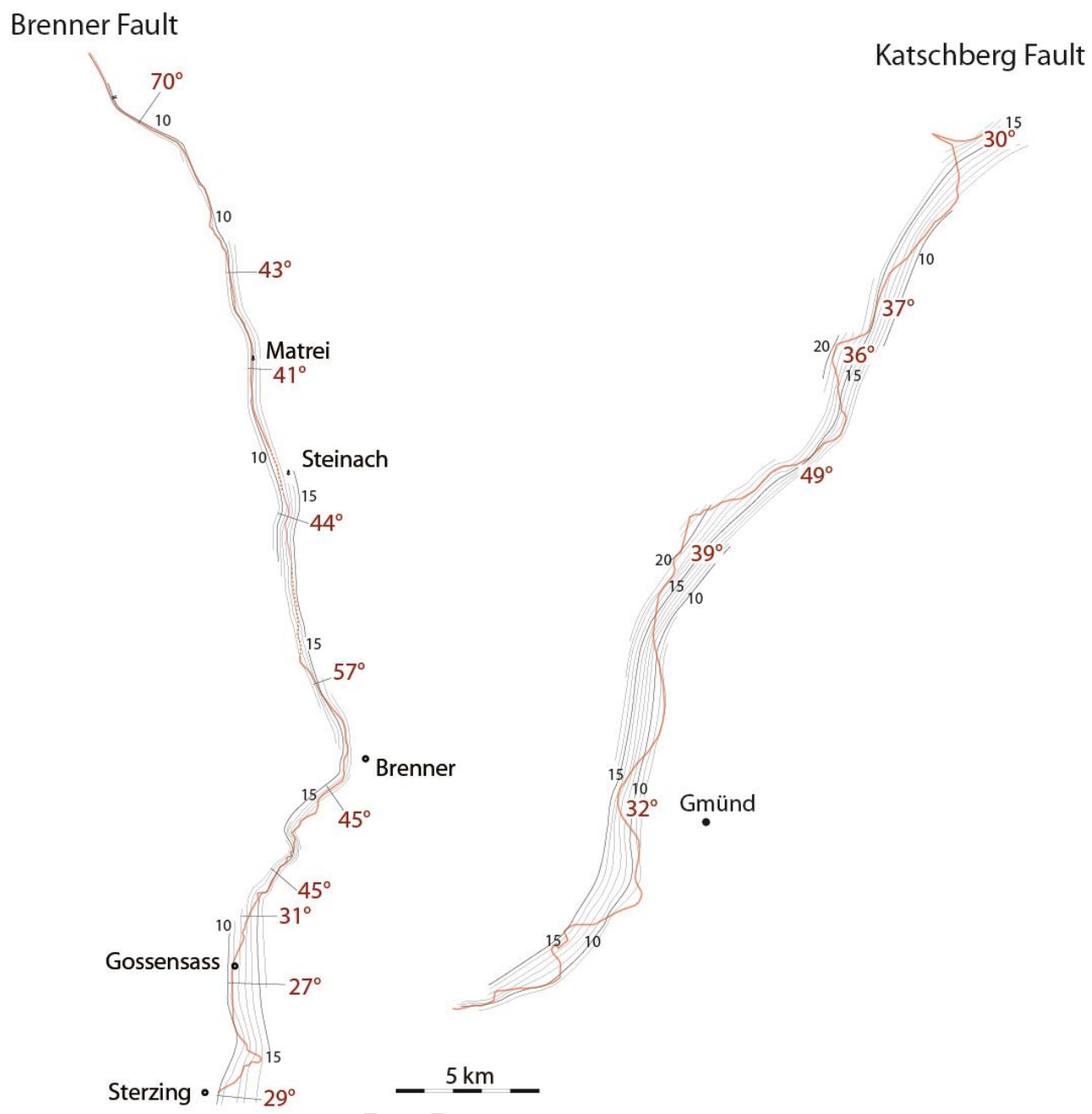

Fig. 13. Contour-maps of the Katschberg and the Brenner normal faults. The contoured plane (red line) is the contact between the base of the Austroalpine nappes and the top of the Penninic nappes. Dashed red line corresponds to inferred fault trace where large quaternary deposits are present. Based on the 1:50.000 maps of the Geologische Bundesanstalt (Rockenschaub and Nowotny, 2009; Rockenschaub et al., 2011) and on Rosenberg and Garcia (2011) for the Brenner Fault. Gray numbers indicate the calculated dip of the plane. Black numbers indicate the elevation of contour lines in 100's of m; Red numbers indicate the local dip of the Penninic/Austroalpine contact.

The KSZS is located above the area corresponding to a deep-seated P-wave velocity transition, inferred to separate a European Slab in the west from an area devoid of slab in the east (Mitterbauer et al., 2011; their figure 8). At the surface, the Katschberg Fault also corresponds to an orogen-scale transition, between an area 
with average elevation $>2000 \mathrm{~m}$ and high relief in the west and one with average elevation of $1500 \mathrm{~m}$ and lower relief in the east (Fig. 1).

The KSZS shows some similarities to the Brenner Fault: its mylonitic belt dips at low angle below the Austroalpine units (Genser and Neubauer, 1989; Scharf et al., 2013a) forming the lateral termination of the Tauern Dome, and the amount of tectono-stratigraphic omission varies along strike, attaining a maximum in the hinge zone of the eastern sub-dome (Fig. 12). However, in contrast to the Brenner case, this maximum value of omission remains rather constant along the central part of the KSZS (Fig. 12). As for the Brenner Fault, contours of the fault trace, i.e., the contact between the Austroalpine units and the Penninic units, which probably corresponds to a brittle fault surface, indicates a steeper orientation $\left(32^{\circ}-49^{\circ}\right.$; Fig. 13) compared to the average orientation of mylonitic foliations (e.g., Scharf et al., 2013a). However, even away from this brittle surface, lithological contacts and foliations within the Glockner nappes attain a $35^{\circ}$ dip towards the SE (Exner, 1980, his figure 10). As shown in figure 14 (Exner, 1980) lithological contacts become steeper towards the fault surface. A similar trend can be assessed for the foliations (Exner, 1980, his Table 2), whose dip is generally $>30^{\circ}$ in the structurally upper part of the KSZS.

If the nappe thicknesses are calculated from cross sections located west of the Katschberg Mylonites (Schmid et al., 2013; their section 7) thinning and eventually omission of nappes along the KSZS can be estimated. As a result the vertical offset varies along strike of the KSZS, passing from 2,5 $\mathrm{km}$ in the south to $11.5 \mathrm{~km}$ in the central part, and going back to less than $2 \mathrm{~km}$ in the north (Fig. 12).

The tectonostratigraphic contacts were inferred to dip with $30-45^{\circ}$ to the east as the mylonitic, top-to-the-East to SE foliations (Genser and Neubauer, 1989; 
their fig. 3), whereas lower dip angles $\left(25-30^{\circ}\right)$ were documented by Scharf et al. (2013a). Contour lines of the base of the hanging-wall indicate dip angles varying from 30 to $49^{\circ}$ (Fig. 13). Cross sections perpendicular to the southern KSZS (Exner, 1980; Schuster et al., 2006; Schmid et al. 2013) show that the lithological contacts within the KSZS steepen from $\sim 20^{\circ}$ at the top of the Venediger Duplex to $>30^{\circ}$ at the top of the Glockner nappes (Fig. 14). The distribution of fabric-measurements in map view (Exner, 1954) confirms that the main foliation in the KSZS steepens slightly towards the hangingwall. This is also manifest on the map-scale (e.g., Map sheet 1:50.000, 181 'Spittal a. d. Drau') showing the steeper dip of lithological contacts within the Matreier Zone and the top of the Glockner nappes, compared to the base of the Glockner Napps and the top of the Venediger Duplex. These geometries are typical for a progressive rotation toward parallelism with the shear plane of a shear zone with a normal sense of movement and they reflect a progressive increase of strain. Under such conditions the dip-angle of the shear plane corresponds to the higher dip angles of lithological contacts and mylonitic foliations measured in the easternmost part of the shear zone. These correspond to $\sim 32^{\circ}$ in the south (Fig. 13) and attain almost $40^{\circ}$ further to the north.

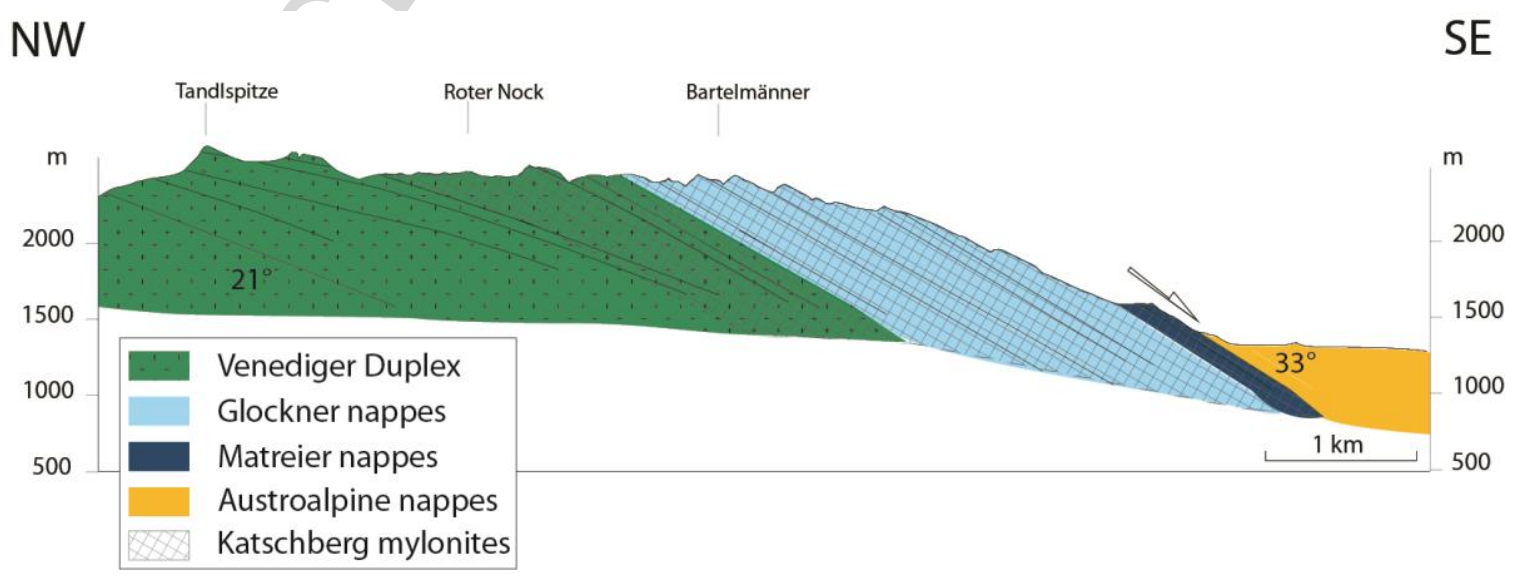


Fig. 14. Cross section of the eastern margin of the Tauern Window modified from Exner (1980). Trace of section is shown in Fig. 3a. Continuous black lines are parallel to main schistosity and lithological contacts. Note the progressive steepening of schistosities in the footwall of the Katschberg Fault, when approaching the hangingwall contact.

\section{Spatial distribution of cooling ages in the Eastern Alps}

Based on a new compilation of zircon and apatite fission track ages (Fig. 5a and b, respectively), we discuss the spatial patterns of cooling in the Eastern Alps. Whereas zircon fission track ages were reset in the Oligo-Miocene only in the Tauern Window and the Rechnitz Window, apatite fission tracks yield Miocene ages in several areas, even outside these windows.

\section{V.1. The Tauern Window}

In the Tauern Window, both apatite and zircon fission track ages show an elongate, irregular, but concentric distribution of ages, younging towards the trace of the axial plane of the Dome (Bertrand et al., 2017). In the western Tauern Window, where more data are available, even higher-temperature systems with closure temperature of $\sim 350{ }^{\circ} \mathrm{C}(\mathrm{Rb} / \mathrm{Sr}$ on biotite; Luth and Willingshofer, 2008) and $\sim 450{ }^{\circ} \mathrm{C}(\mathrm{U}-\mathrm{Pb}$ apatite, Schneider et al., 2015) show this elongate concentric pattern whose long axis strikes sub-parallel to the sub-domes. If age/elevation correlations are used to extrapolate all ages to one and the same height, the contour-line patterns simplify and their elliptical shapes become more obvious, especially for the apatites (Bertrand et al., 2017).

Based on previous age compilations and iso-age contour maps, it was suggested that two age trends dominate the pattern of the western sub-dome (Luth and Willingshofer, 2008; Schneider et al., 2015). One trend, showing younger ages 
towards the hinge of the Tauern antiform, was inferred to indicate the effect of folding (Luth and Willingshofer, 2008). The other trend, showing a westward younging of ages was inferred to reflect the contribution of extensional unroofing along the Brenner Fault (Luth and Willingshofer, 2008). However, new data and compilations of fission track ages (Bertrand et al., 2017; fig. 5) show that younging towards the Brenner Fault is not visible in the iso-age maps of apatites and zircons (Fig. 5). The more obvious trend is the younging of ages towards an ENE-striking axis, being almost identical with the trace of the fold axial plane of the western subdome (compare Fig. 5 and Fig. 9b). When plotted along a section striking parallel to the hinge of the Tauern Dome (Fig. 16a; Bertrand et al., 2017) both apatite and zircon fission track ages decrease in the immediate vicinity $(\sim 10 \mathrm{~km})$ of the fault plane, but not further away (Fig. 15a; Bertrand et al., 2017). These age patterns probably reflect the younger activity of the mylonitic and cataclasitic belts of the Brenner and the Katschberg faults.

Younging of cooling ages toward the Katschberg Fault was proposed by Favaro et al. (2015) and Scharf et al. (2016), based on new and compiled $\mathrm{Rb} / \mathrm{Sr}$ isochron ages (mainly whole rock-biotite) and ${ }^{40} \mathrm{Ar} /{ }^{39} \mathrm{Ar}$ laser ablation ages of white mica from the southern and northeastern margins of the eastern sub-dome, respectively. Such a trend is in contrast to the fission track data of Bertrand et al. (2017; Fig. 15) that do not show such a SE-directed younging. However, the younging trend of Favaro et al. (2015) is only visible if the data from both Sonnblick and Hochalm domes are plotted in one and the same section cross-cutting the main regional structures. Scharf et al. (2016) interpret the cooling-age pattern of younger ${ }^{40} \mathrm{Ar} /{ }^{39} \mathrm{Ar}$ white mica ages (c. $17 \mathrm{Ma}$ ) at the top of the Katschberg Fault (i.e., at the Penninic/Austroalpine contact) and older ages (c. $20 \mathrm{Ma}$ ) at the base of the 
Katschberg Fault (i.e., ca. $5 \mathrm{~km}$ below the top of the Katschberg Fault) as due to varying grain sizes in the mylonite zone. Smaller grains at the top of the fault have lower closure temperature, of c. $400{ }^{\circ} \mathrm{C}$, hence, younger cooling ages with respect to its base, where larger grain sizes are predicted to be associated with closure $\mathrm{T}$ of ca. $445^{\circ} \mathrm{C}$.

Age data plotted along a section perpendicular to the fold axis of the western Tauern Window (Fig. 15b; Bertrand et al., 2017) show a bowl-curve, due to the relatively symmetric younging towards the hinge of the dome. As shown in figure $15 \mathrm{~b}$ this pattern is observed for cooling ages derived from all thermochronometers that have been used in the literature on the western Tauern Window. These are, apatite FT (Bertrand et al., 2017), zircon FT (Bertrand et al., 2017), Rb/Sr and K/Ar on biotite (Most, 2003, for compilation), K/Ar on white mica (Most, 2003, for compilation) and U-Pb on apatite (Schneider et al., 2015). The wavelength of the bowl-shape increases progressively from geochronometers with the highest, to the ones with the lowest closure temperature (Fig. 15b), but the site of the youngest cooling ages is nearly the same for all geochronometers (Fig. 15b). This bowl-shape pattern in distance vs. age plots is typical for areas where exhumation took place by large-scale folding and erosion, as previously observed in the Olympic Mts. (Batt and Brandon, 2001) and in numerical, thermo-kinematic models of folding and erosion (Batt and Braun, 1997). 


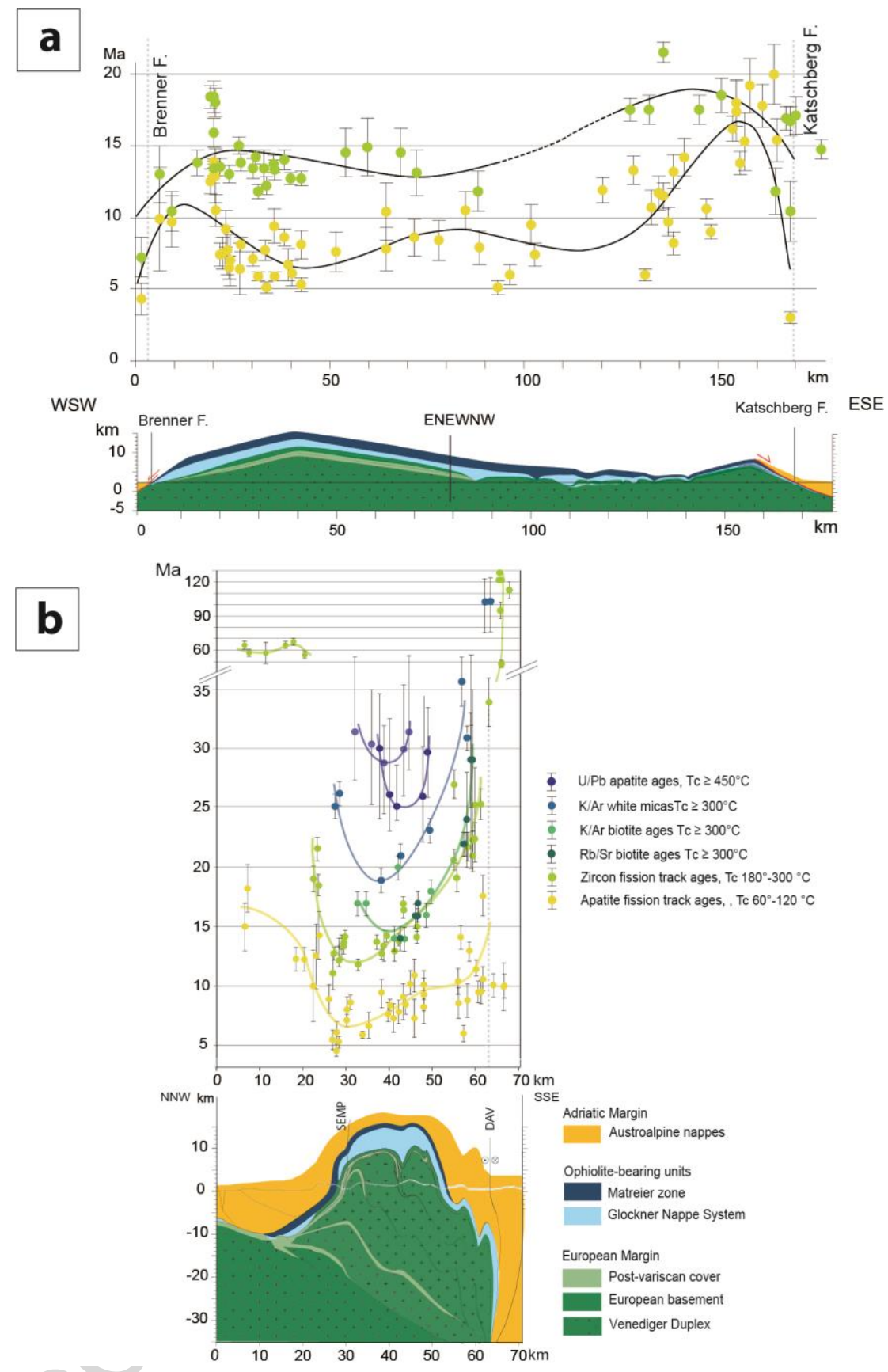

Fig. 15. Cooling ages projected along an orogen-parallel (a) and an orogen-perpendicular (b) cross section, based on the compilation of Bertrand et al. (2017), on the compilation of Most (2000), and on Schneider et al. (2015). Traces of the cross sections are shown in figure 9b. a) Age distribution projected from a distance of maximum $5 \mathrm{~km}$ from either side of axial-plane-parallel trace across the Tauern Window. Modified from Bertrand et al. (2017) b) Age distribution along a section perpendicular to the fold axis of the western sub-dome of the Tauern Window. Age date are projected from samples having a maximum distance of $5 \mathrm{~km}$ from the section for FT apatite and zircons, $\mathrm{U} / \mathrm{Pb}$ ages are distinguished into two populations (darker and lighter blue circles), corresponding respectively to a cross section located west and East of the trace of the section shown in Fig. 9b. Closure temperatures for 
apatite and zircon fission tracks are taken from Gallagher et al. (1998) and Hurford and Green (1983), respectively. For $\mathrm{U} / \mathrm{Pb}$ on apatite closure temperature is based on Chamberlain and Bowring (2000).

Cooling ages in the western sub-dome are slightly (2-3 Ma), but systematically younger than in the eastern sub-dome (Dunkl et al., 2003; Bertrand et al., 2017). This difference is inferred to result from coeval exhumation of both sub-domes taking place at different rates (Bertrand et al., 2017). As shown by thermo-kinematic models, faster exhumation rates during folding and erosion within a given time range, lead to younger cooling ages (Bertrand et al., 2017). Inversion of thermochronologic data of the Tauern Window confirms that exhumation rates were higher in the western sub-dome compared to the eastern one (Fox et al., 2016; Bertrand et al., 2017). This result is corroborated by detrital thermochronological investigations (Gemignani et al., 2017). However, alternative interpretations, suggesting a later initiation of exhumation in the western sub-dome were proposed by Scharf et al. (2013a), Schmid et al. (2013), and Favaro et al. (2015).

\section{V.2. Cooling ages in the Austroalpine Units}

The map of Fig. 5a shows that outside the Tauern Dome zircon fission track ages were reset during collision (Fig. 5a; Brix et al., 1996; Stöckhert et al., 1999; Steenken et al., 2002; Most, 2003), in an area to the SW of the Tauern Window, but also along a belt bordering the western margin of the Dolomites Indenter (Fig. 5a) and in the Rechnitz Window. Both these areas were strongly shortened during collision and their cooling ages are similar to those of the Tauern Window (Fig. 5a). 
Hence, the spatial distribution of Miocene ages closely corresponds to the areas affected by the largest shortening due to indentation. Areas that do not show any structural evidence of shortening related to the Dolomites Indenter, as the areas east and west of the Tauern Window show pre-Cenozoic zircon fission track ages (Fig. 5).

Cenozoic cooling ages derived from apatite fission tracks are widespread in the Eastern Alps compared to zircon fission track ages (compiled data in Fig. 5 and references in its figure caption). They cover the area described above for the reset zircon ages in addition to large parts of the Ötztal Basement (Fig. 2), a belt striking parallel to- and located immediately south of the SEMP Fault (Fig. 5a), and a smaller area adjacent to the eastern border of the Tauern Window, delimited by the Hochstuhl, and the Mölltal faults (Figs. 2 and 3a).

The hanging-wall of the Brenner Fault is characterised by apatite fission track ages varying between 60 and 20 Ma whereas in the remaining parts of the Ötztal Basement (Fig. 5b) apatite fission track ages are $<20$ Ma. This marked difference may be explained by tilting of the hanging-wall during rotation of the Brenner Fault towards a lower angle of dip, as commonly observed in extensional fault systems (e.g., Buck, 1988). Such tilting would enhance burial in the vicinity of the Brenner Fault and favor the preservation of older ages.

In the area located immediately east of the Tauern Window apatite ages are younger along the eastern continuation of the fold hinges of the Hochalm Dome (Fig. 5b), suggesting that this structure also affected part of the Austroalpine units. Further east apatite ages tend to become older, passing from Miocene ages west of the Lavanttal Fault (Fig. 2; 5b) to Eocene and Cretaceous ages east of this fault (Fig. 
5b). Only in the Rechnitz Window, at the very eastern end of the Alps, ages are again reset to the Miocene.

The age differences described above coincide with marked changes in the cooling rates of these areas (fig. 16) varying from $17-19{ }^{\circ} \mathrm{C} / \mathrm{Ma}$ in the Tauern Window, and $2-3^{\circ} \mathrm{C} / \mathrm{Ma}$ in the Australpine nappes east of the Tauern Window.

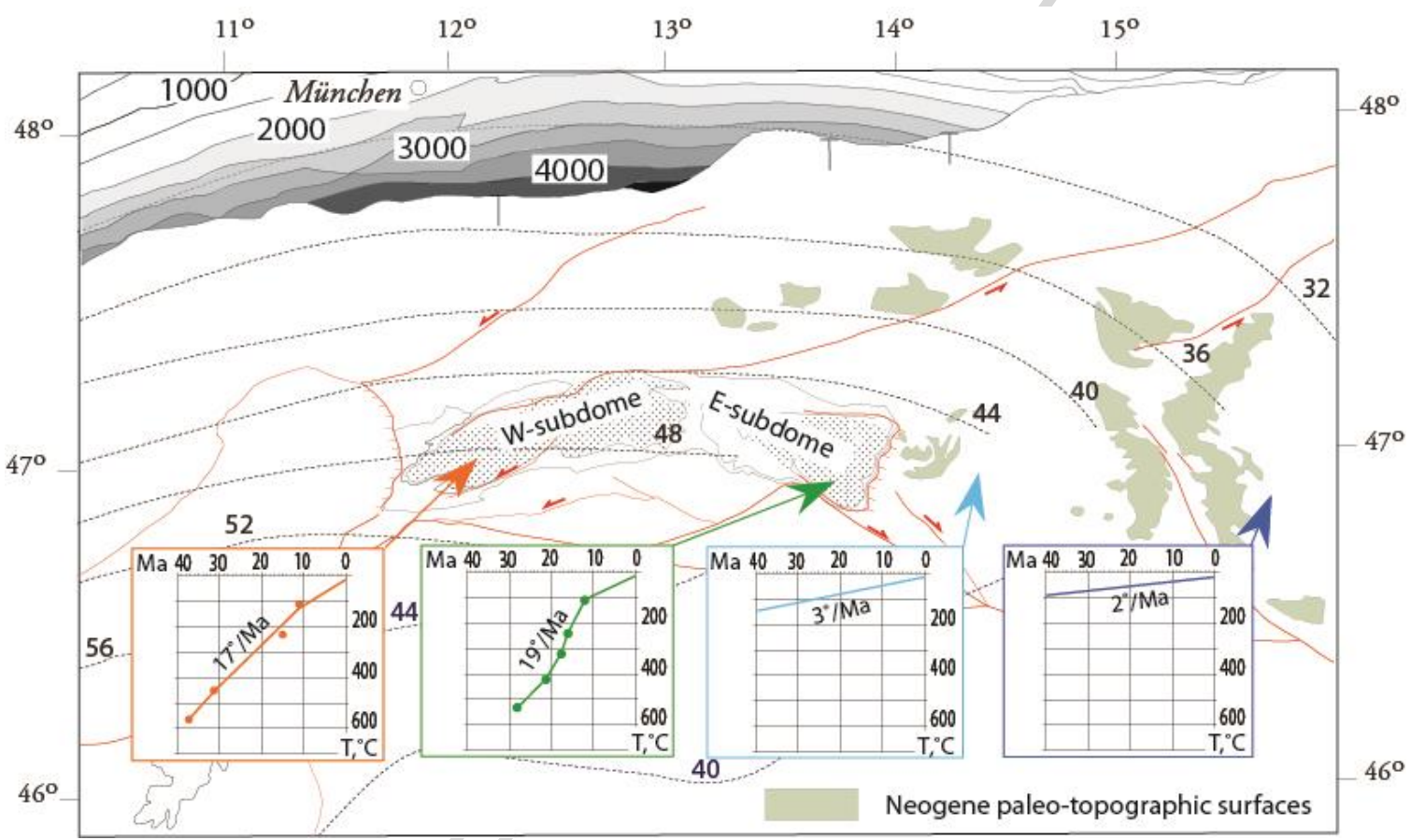

Fig. 16. Along-strike changes in the cooling gradients of the Eastern Alps. Data compiled after Schneider et al. (2015), Favaro et al. (2015), Hejl (1997). Contours of sediment thickness in the Molasse Basin of the Eastern Alps after Bigi et al. (1990). Numbers in Molasse Basin indicate present-day thicknesses of Oligocene-Neogene sediments in meters. Stippled lines indicate contour lines of European Moho; associated numbers indicate Moho depth in $\mathrm{km}$ after Spada et al. (2013). End points of cross sections of figure 6 are shown. Neogene paleo-surfaces are from Hejl (1997) and Frisch et al. (2001). Note the rapid decrease of thickness of Molasse sediments east of Tauern Window, where Moho turns into a NW strike and the increasing preservation of Neogene paleo-topographic surfaces.

A lateral gradient showing increasing metamorphic temperature towards the fault plane is expected to exist in exhumed footwalls of normal faults, (Foster et al. 2001; Burg et al., 2004; Bertrand et al., 2017). Assuming fault-parallel 
displacements, surface rocks closer to the fault trace are those that were exhumed from greater depth, and the last ones to cross the isograd corresponding to their closure temperature. Indeed, younging of ages and increasing temperatures towards the fault plane are, observed in map view in the footwalls of normal faults (John and Foster, 1993; Foster et al., 2010). Such trends (Fig. 17) have not been observed in the Tauern Window (Fig. 16b; Bertrand et al., 2017), except locally (Favaro et al., 2015).
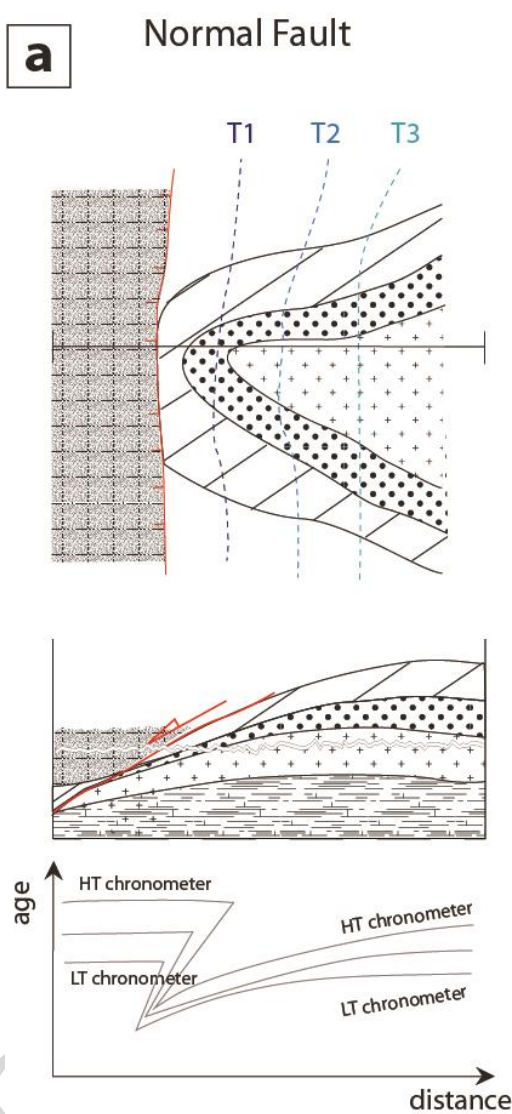
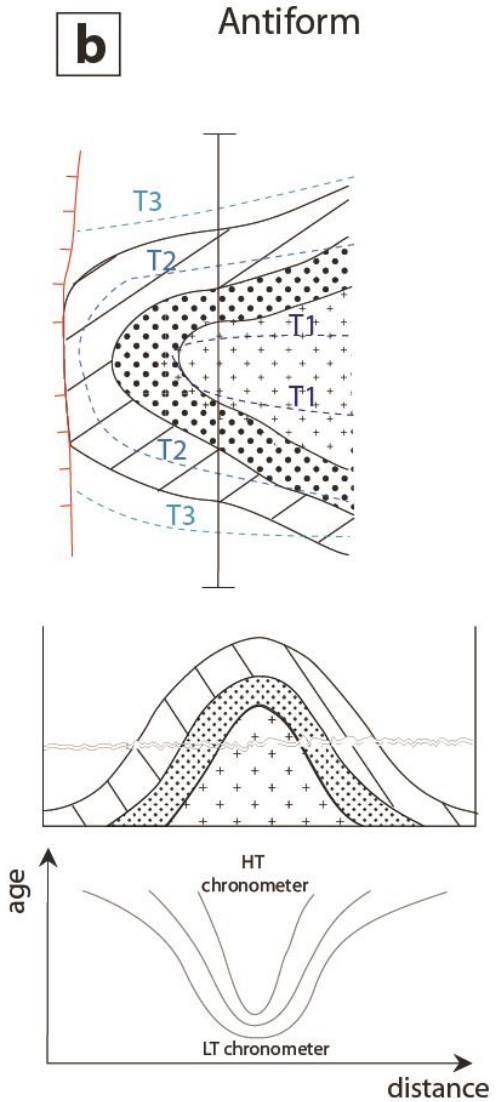

Fig. 17. Schematic diagrams showing the folded footwall of a normal fault. a) Cooling is determined by extensional unroofing and cooling ages in the footwall are progressively younger towards the fault trace. b) Cooling is determined by folding and erosion of the antiformCooling patterns are inspired from Foster et al. (2010) and Robinson et al. (2001) for a), and from Batt and Braun (1997) and Bertrand et al. (2017) for b). T1, T2, T3, indicate hypothetical contour lines of ages in map view. Ages increase from T1 to T3. Not to scale. 
Age vs. distance diagrams parallel to the commonly inferred Oligo-Miocene direction of maximum extension in the Tauern Window show a large-scale younging of fission-track ages away from the fault trace (Fig. 15) and only on the local scale do ages become younger toward the fault. In other words, only within the mylonitic/cataclastic zones of the $\mathrm{BF}$ and the $\mathrm{KF}$ cooling ages are younger than in the remaining footwall, i.e., in an area of only few $\mathrm{km}$ width. This distribution is in contrast to extensional models of exhumation (e.g., Fig. 17). Numerous examples from extensional metamorphic core complexes do show that cooling ages of the footwall decrease systematically towards the trace of the extensional detachment (e.g., John and Howard, 1995; Foster et al., 2001; Stöckli, 2005; Brichau et al., 2006; Foster et al., 2010; Robinson et al., 2010).

VI. Physical models simulating the formation of the Tauern Window 

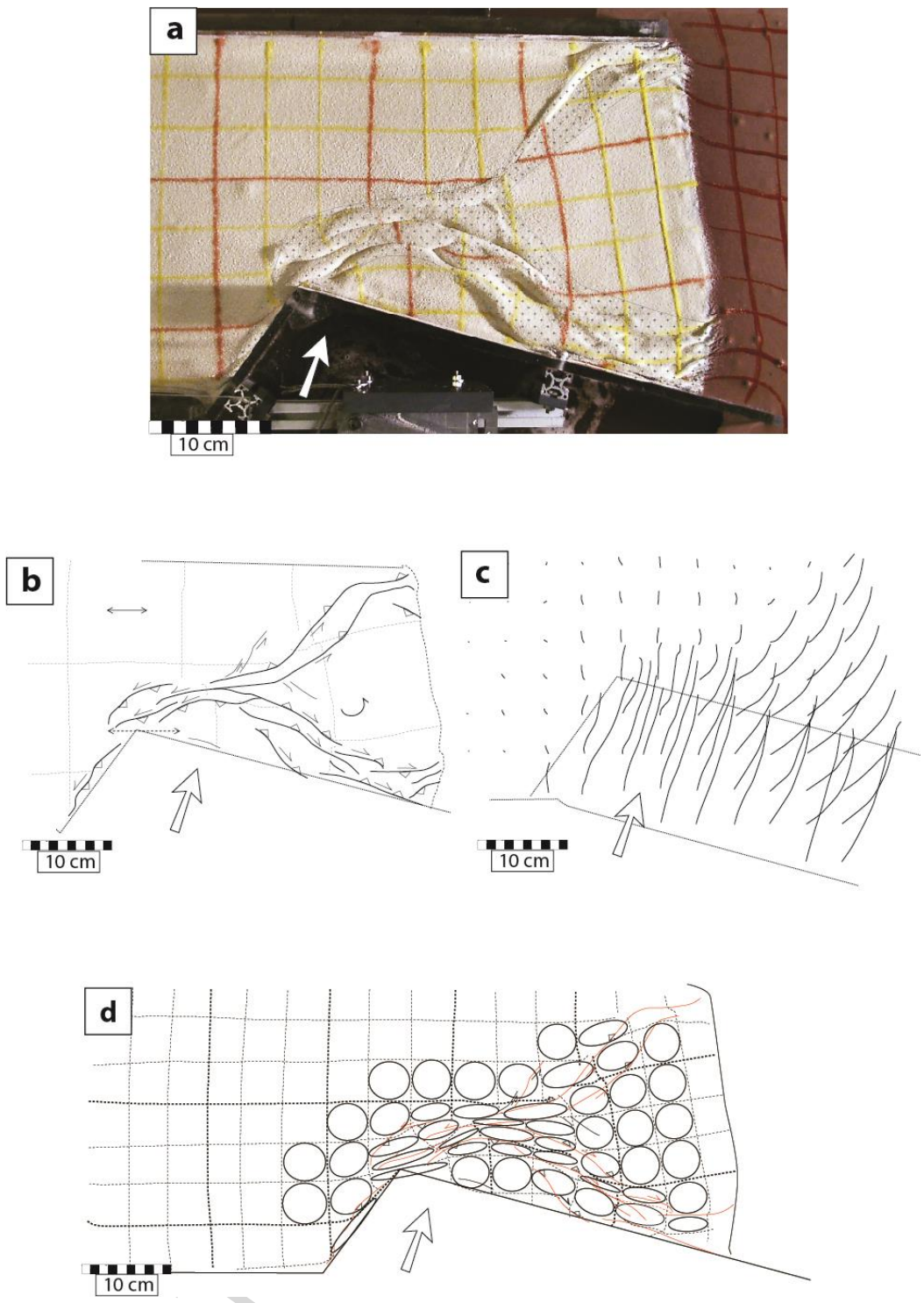

Fig. 18. Results of analogue experiment designed to simulate deformation in front of the Dolomites indenter. Modified from Rosenberg et al. (2007). a) Photograph of the surface of the model after $10 \mathrm{~cm}$ of shortening, corresponding to approximately $50 \mathrm{~km}$. The pinkish area with red grid lines located at the right side of the model consists of the same analogue asthenosphere, mantle, and lower crust as in the rest of the model, but it lacks the upper crust (sand). The absence of the sand layer makes the lateral confinement weaker than the rest of the model. b) Sketch of the same model, showing the major structures that accommodated deformation c) Displacement field of the same model, but after $14 \mathrm{~cm}$ of shortening. d) 2D, horizontal sections, of deformation ellipsoids. Area covered by small crosses represents area in which shortening was localized. The length ratio between western boundary of the indenter and the N-S extension of the model in front of the indenter is 0.67, corresponding to that observed in the Eastern Alps. The ratio between the 
northern and western margins of the indenter is 0.29 , slightly larger than that of the Dolomites Indenter, which is 0.24 .

Analogue experiments inspired by indentation models of India and Asia (Tapponnier et al., 1982; Davy and Cobbold, 1988) were performed to assess the role of the Dolomites Indenter on the Cenozoic fault and fold pattern of the Eastern Alps (Ratschbacher et al., 1991a; Rosenberg et al., 2004; 2007; Luth et al., 2013; van Gelder et al., 2017). In order to simplify the boundary conditions, and in spite of its well-documented Neogene shortening (Schönborn, 1999; Nussbaum, 2000; Doglioni et al., 2007), all models excepted van Gelder et al. (2017) used a rigid material to simulate the Dolomites Indenter. Undeformable boundaries along the western and northern limits of the box, and a deformable one along the eastern termination completed the initial set-up. Varying rheologies, indenter geometries, and convergence direction resulted in varying fault patterns, some of which were sufficiently robust to be observed in all models. We describe these patterns below. First, indentation induced minor amounts $(<15 \%)$ of lateral extrusion unless the lithosphere was completely eliminated (Ratschbacher et al., 1991a). In the model commonly quoted to link the Cenozoic fault pattern of the Eastern Alps to a process of lateral extrusion (Ratschbacher et al., 1991a; their model V) the eastern margin of the analogue lithosphere of the Eastern Alps was bordered by an asthenosphere, but no lithosphere. Under such conditions, lateral flow of analogue lithosphere occurs spontaneously, even in the absence of indentation and north-south convergence, in order to reduce the lateral gradient of gravitational potential energy. A second common point to all experiments is the occurrence of significant shortening accommodated by folding in the area located immediately north of the indenter corner (Ratschbacher et al., 1991a). Even in those models, where lateral extrusion is 
large, the area in front of the indenter corner is mainly affected by shortening (Ratschbacher et al., 1991a; Rosenberg et al., 2004, 2007). A third characteristic of all models is the formation of a deformation wedge widening eastward, bounded by sinistral faults in the north and by dextral ones in the south (Ratschbacher et al., 1991a; Rosenberg et al., 2004, 2007, van Gelder et al., 2017). Such deformation structures are observed in many other indentation experiments (e.g., Davy and Cobbold, 1988), whose boundary conditions were not specific to the ones of the Eastern Alps. Hence, we consider their natural occurrence in front of orogenic indenters as the result of indentation itself. In the Eastern Alps these structures are represented by the upright folds of the Tauern Window (Fig. 3) in front of the Indenter corner, the newly-formed sinistral SEMP fault system in the north of the deforming wedge (Figs. 2 and 3), and the pre-existing dextral Periadriatic Fault (Pustertal-Gailtal segment), that defines the southern margin of the extruding wedge.

A number of other large-scale structures, characteristic of the Tauern Window and its surrounding areas could be reproduced by simple, indentation experiments (Rosenberg et al., 2004; 2007). These are: 1) The arc-shape (Figs. 7a, 9b, and 18 of the Tauern Dome. 2) The sinistral shear zones associated with- and parallel to the ENE-striking upright folds of the western Tauern sub-dome (Figs. 1b and 18). 3) The larger wavelength of the eastern upright folds and higher amplitude of the western ones (Figs. 9b and 18). 4) The area of uplift corresponding to localized shortening within an arched-shaped area in front of the indenter (Fig. 18) and coinciding to reset, younger cooling ages in the Eastern Alps (Fig. 5); The position and orientation of the sinistral fault system delimiting the folded arc to the north correspond to the SEMP Fault in the Eastern Alps (Fig. 2), causing younger 
cooling ages south of it (Figs. 5 and 18). 6) Orogen-parallel extension localized in front of the indenter corner (Fig. 18) corresponding to the Brenner Fault in the Eastern Alps (Fig. 2). The temporal evolution of these structures is shown in the experiment movie (Movie 1).

\section{Timing of exhumation and indentation}

Whereas most authors agree on a causal relationship between Dolomites indentation and exhumation of the Tauern Window (e.g., Cornelius, 1940; Linzer et al., 2002; Rosenberg et al., 2004; 2007; Schmid et al., 2013), the precise timing of indentation is still debated. Differences in the interpretations stem from the different nature of the data-sets, namely, stratigraphic ages from the Dolomites Indenter (Schmid et al., 2013; Scharf et al., 2013a), cooling ages in the exhumed basement rocks in front of the indenter (Pomella et al., 2011; 2012; Bertrand et al., 2017; Schneider et al., 2015), deformation ages from high strain zones immediately adjacent to the indenter margin (Martin et al., 1993; Mancktelow et al., 2001; Müller et al., 2001), and within the Tauern Window (Schneider et al. 2013), and finally, formational ages inferred to be synchronous to folding within the Tauern Window (Cliff et al., 2015).

Schmid et al. (2013) and Scharf et al. (2013a) suggested that indentation did not start before $21 \mathrm{Ma}$, which is the age of the youngest marine sediments deposited in the footwall of the Giudicarie fold and thrust belt (Luciani and Silvestrini, 1996). The occurrence of deep marine sedimentation was considered to be incompatible with sinistral, transpressive displacements along the Giudicarie fold and thrust belt 
(Schmid et al., 2013). Alternatively, based on the spatial pattern of cooling ages in the Tauern Window (Figs. 5a and 15b), inferred to result from upright folding and exhumation during indentation, Schneider et al. (2015) and Bertrand et al. (2017) suggested that exhumation due to indentation initiated at $\sim 30 \mathrm{Ma}$.

It is noteworthy, that even ages derived from geochronometers with closure temperature $\sim 450{ }^{\circ} \mathrm{C}$ (Schneider et al., 2015) do show a bell shape on distance vs. age diagrams (Fig. 15b) as the ages from low-T geochronometers, suggesting that all cooling ages are related to exhumation during the same folding event. Hence, if the antiform of the western Tauern Window resulted from indentation, this process may have started before $30 \mathrm{Ma}$.

Based on the interpretation of syn-tectonic emplacement of 32 Ma old tonalitic intrusions along the Giudicarie Fault System (Dal Piaz et al., 1988), its displacement, hence, indentation was inferred to have started around $32 \mathrm{Ma}$ (Martin, 1993; Mancktelow et al., 2001; Müller et al., 2001). Alternatively, it was suggested that the tonalitic intrusions were emplaced syn-tectonically along the EW-striking Periadriatic Fault and later rotated into parallelism to the Giudicarie Fault System, during Dolomites indentation that was inferred to initiate during the Late Oligocene/Early Miocene (Pomella et al., 2012).

Finally, the contour maps of zircon fission-track ages of figure 5a, show that young ages (11-26 Ma) that characterize large parts of the Tauern Window continue in an intermittent fashion along a band that borders the western margin of the Dolomites Indenter. In contrast, ages from all samples located further west are with no exception significantly older than $26 \mathrm{Ma}$, (Fig. 5a). The compilation of zircon fission track ages (Fig. 5a) shows that west of the Giudicarie Fault System, sample ages are older than $40 \mathrm{Ma}$, whereas along the Giudicarie Fault System, along the 
easternmost Tonale Line and in the Tauern Window samples are younger than 40 Ma, and generally younger than 26 Ma. Therefore, displacement of the Dolomites Indenter, along the Giudicarie Fault System must be $\geq 26 \mathrm{Ma}$.

VIII. Discussion

\section{VIII.1. Crustal structure and exhumation}

The cross sections of figures 4 and 6 show that the northern margin of the Tauern Window coincides with the northern margin of the antiformal stack of European basement nappes (Venediger Duplex). The amplitude of this antiformal structure decreases and almost disappears, both in the west and in the east (Fig. 19) of the Tauern Window. The sub-horizontal orientation of Creataceous nappes (Fig. $7 \mathrm{~b})$ and the Cretaceous age of low-temperature chronometers west of the Tauern Window (Fig. 5a) suggest that the European nappes below the Ötztal nappe (Fig. 2) are not folded into a large antiformal structure. East of the Tauern Window this antiformal structure of European basement nappes disappears gradually (Figs. 6 and 19), or abruptly (Schmid et al., 2004, their figure 3e), based on the following lines of evidence: first, numerous paleo-topographic surfaces of inferred Neogene age are preserved between the eastern margin of the Tauern Window and the Styrian Basin, suggesting limited amounts of erosion during Neogene times. Second, apatite fission-track ages are pre-Oligocene (Fig. 5b), corroborating that no significant uplift and erosion occurred throughout the collisional history. Third, the Moho depth decreases rapidly east of the Tauern Window, passing from $42 \mathrm{~km}$ east of the Katschberg Fault to $32 \mathrm{~km}$ at the margin of the Styrian Basin (Fig. 1), but the nappes exposed at the surface still belong to the Upper Austroalpine (Fig. 2). 
Assuming a thickness of at least $10 \mathrm{~km}$ of Austroalpine nappes (Fig. 12) plus some $5 \mathrm{~km}$ of Glockner and Matreier nappes (Fig. 12), the European basement varies between 27 and $17 \mathrm{~km}$ thickness. These values are not larger than those of the European crust, located below the Molasse Basin, where it suffered no shortening during collision (Fig. 6). Therefore, the presence of an antiformal stack of European basement nappes in the Eastern Alps is restricted to the area characterized by the deepest Moho, suggesting that the prime cause of formation and exhumation of this antiformal stack is the accommodation of shortening.
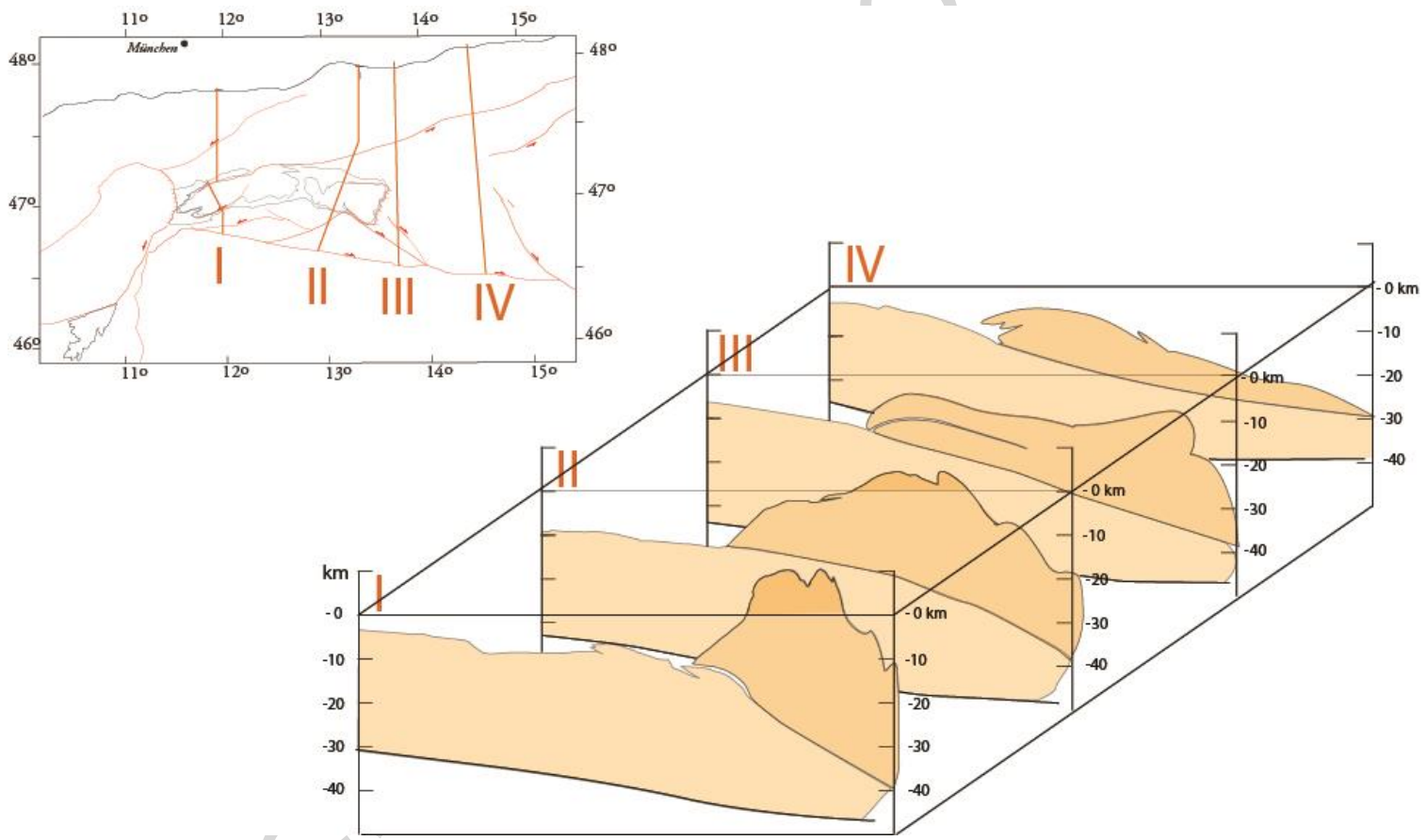

Fig. 19: Simplified, serial cross sections showing the inferred geometry and position of the European basement in 4 sub-parallel cross sections. Note that in section IV the nappe pile is less exhumed and less buried than in the other sections. Sections I, II, and II are modified from Rosenberg et al. (2015). Section IV is modified from Prey (1980).

Line-length-balancing of the top of the European basement duplex suggests that $60 \mathrm{~km}$ of shortening were accommodated in the western Tauern Window, 38 $\mathrm{km}$ in the eastern Tauern Window, and $27 \mathrm{~km}$ east of the Tauern Window (Rosenberg et al., 2015). This westward increase in shortening is associated to an 
increase in amplitude and decrease in the wavelength of the European nappe stack in cross section (Fig. 6), in spite of similar cross sectional areas (Rosenberg et al., 2015; Fig. 19). These geometrical relationships indicate that the westward increase of shortening was accommodated by vertical thickening.

In summary, the three cross sections of figure 6 show a correlation between cooling age, amount of exhumation, metamorphic degree, and amount of shortening. The easternmost cross section shows the least shortening, the least amount of exhumation, the lowest temperature of Cenozoic metamorphism and the oldest ages of cooling. The western section shows the largest shortening, the largest amount of exhumation, the highest temperature of Cenozoic metamorphism and the youngest cooling ages (Bertrand et al., 2017). The central section (eastern Tauern Window) shows intermediate characteristics between the previous two concerning the four points discussed above.

Based on the comparison of the estimated sediment budgets deposited in the circum-Alpine basins and the estimated volumes of eroded material from the Eastern Alpine chain, it was suggested (Kuhlemann et al., 2001) that less than 20\% of denudation of the Tauern Window could be attributed to erosional processes, hence, that extensional denudation was responsible for $>80 \%$ of the total exhumation of the window. However, this conclusion is biased by two major facts: First, the enormous difficulty in the reliable determinations of volume, source and age of sediments in the circumalpine basins. Second, the analysis of Kuhlemann et al. (2001) was restricted to the time period between 22 and 12 Ma that was suggested to be the time of faster exhumation, but it was applied to the bulk volume of denudation of the Tauern Window. New calculations of exhumation rates extrapolated to the entire surface of the Tauern Window (Bertrand et al., 2017) 
show that faster exhumation rates in the 22-12 Ma period existed, but only locally, whereas over the entire surface of the Tauern Window, no significant change took place after 12 Ma. In addition, Bertrand et al. (2017) argue that exhumation rates were highest in pre-Miocene times. Restricting the sediment-volume calculation to a small time interval of the denudation history, but comparing it to the bulk volume of denudation of the Tauern Window must, a priori, result in a small portion of the latter volume only. The cross sectional area of material eroded from the Tauern Window along the TRANSALP Line corresponds to $700 \mathrm{~km}^{2}$ (Fig. 6c). In the same section the area occupied by sediments of the German Molasse basin corresponds to $320 \mathrm{~km}^{2}$. Adding the estimated amount of eroded Molasse deposits (Baran et al., 2014) a total area of $362 \mathrm{~km}^{2}$ results. Therefore, based on this $2 \mathrm{D}$ geometric comparison more than $50 \%$ of the excess area of the Tauern Dome is found in the Molasse Basin, which is inferred to contain only $1 / 3$ of the eroded volume of the Eastern Alps (Kuhlemann et al., 2002), because large volumes of sediments were deposited in the Pannonian and other circum-Alpine basins (Kuhlemann et al., 2001; 2002). Therefore, in spite of the large volume of material that needs to be transported to a foreland basin in order to explain exhumation of the Tauern Window by folding and erosion, the accommodation of this material in the CircumAlpine- and in the Molasse Basins is likely.

\section{VIII.2. Balancing collisional displacements}

Balancing collisional displacements is difficult, because material flow was accommodated within planes oriented both parallel and perpendicular to the convergence direction (Behrmann, 1988; Selverstone, 1988). In addition, no agreement exists yet on the amount of displacement of the first-order normal faults. 

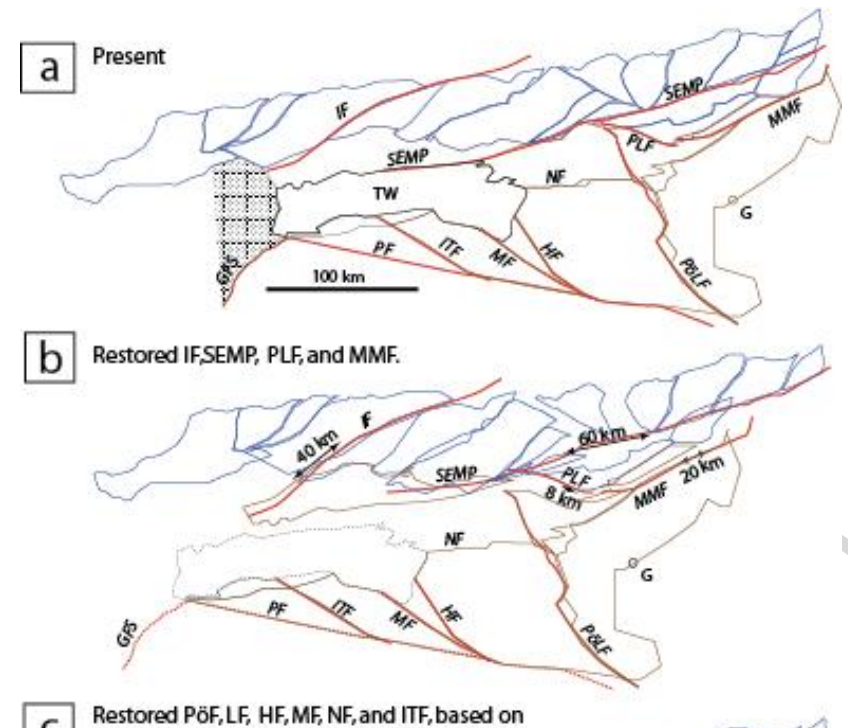

C Restored PöF, LF, HF, MF, NF, and ITF, based on
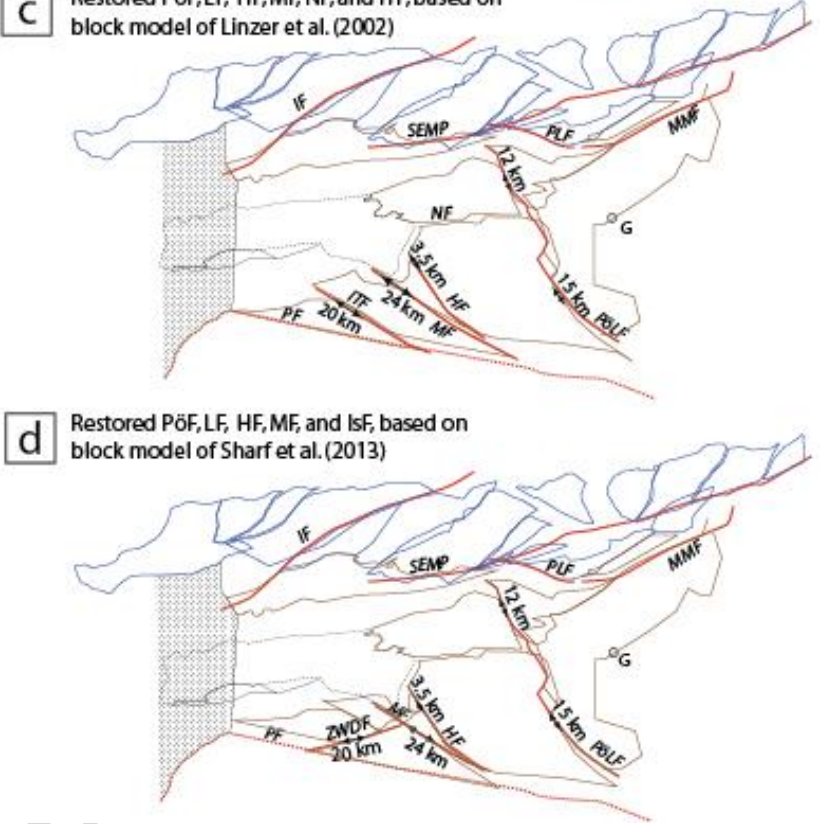

Fig. 20. Retrodeformation of major strike-slip displacements in the East-Alpine orogenic wedge. Most faults are active at the same time, hence the sequence of a) to d) is not a chronological, but just as a spatial, step-by-step reconstruction. GFS: Giudicarie Fault System; HF: Hochstuhl Fault; IF: Inntal Fault; ITF: Iseltal Fault; MF: Mölltal Fault; MMF: MurMürz Fault; PF: Periadriatic Fault; PöLF: Pöls-Lavanttal FaultSEMP: Salzach-EnnstalMariazell-Puchberg Fault; ZWDF: Zwischenbergen-Wöllatratten-Drau Fault. G: Graz. Blue lines refer to North Calcareous Alps, brown lines to the Austroalpine basement. d) shows the reconstruction based on the block subdivision of Scharf et al. (2013a). This model does not take into account the dextral Iseltal Fault, but rather the sinistral Drau Fault, in contrast to Linzer et al. (2002). 

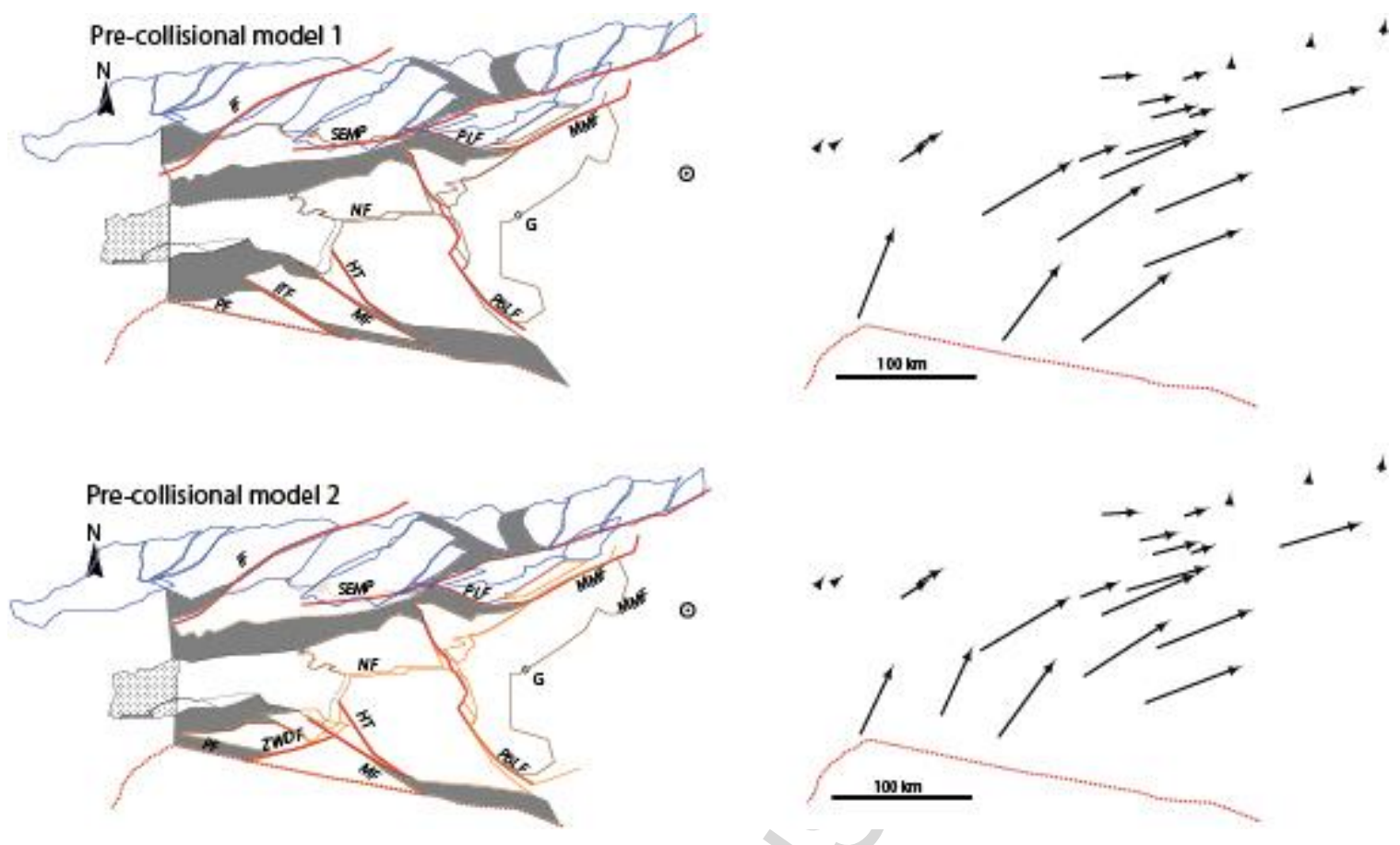

Fig. 21. Map-view restoration of strike-slip displacements in the Eastern Alps. Model 1 follows the subdivision into fault blocks of Linzer et al., (2002), but applying different absolute values of displacements (see text for values and references). Model 2 follows the subdivision into fault blocks of Scharf et al., (2013) for the southernmost part of the map, and the same displacement of model 1. Displacement vectors are reconstructed for each block of the maps on the left hand side are shown on the right part of the figure. Note the progressive E-directed rotation from west to east. The southwesternmost block has been displaced by almost $70 \mathrm{~km}$ towards the NNE. Both the orientation and the amount of displacement are in agreement with the those independently constrained for the Giudicarie Fault System based on the offset of the Austroalpine/Southalpine boundary. Dark-gray areas correspond to gaps between the tectonic blocks that result from lateral displacement during retrodeformation. These gaps represent areas of compression during collision. Stippled areas represent overlaps corresponding to extension during collision. Abbreviations of fault names as in Fig. 20.

Several studies attempted to restore collisional displacements in the Eastern Alps by retro-deforming displacements only along the major strike-slip faults (Frisch et al., 1998; 2000; Linzer et al. 2002; Rosenberg et al., 2007), or by retrodeforming both strike-slip and normal faults (Favaro et al. 2017). The results of the 
former 2D, map-view restorations, show where and how much extension and shortening were needed to maintain compatibility between the blocks displaced along the strike-slip faults. This approach does not require the yet unresolved amount of extensional displacement along the Katschberg and Brenner faults to be part of the boundary conditions. In contrast these values rather result from this retrodeformation. Using the subdivision into tectonic blocks defined by Linzer et al. (2002), we performed a similar restoration, also restricted to strike-slip displacements (Figs. 20, 21), but using different displacement amounts along the strike-slip faults, based on the more recent literature. The Mölltal Fault (Fig. 20) is retro-deformed applying a displacement of 24 km (Kurz and Neubauer, 1996; Scharf et al. 2013a) instead of $50 \mathrm{~km}$ (Linzer et al. 2002, their figure 10), the Hochstuhl Fault is retro-deformed applying a displacement of $3.5 \mathrm{~km}$ (Wölfler et al. 2008) instead of $20 \mathrm{~km}$ (Linzer et al., 2002), the Mur-Mürz Fault is retro-deformed applying a displacement of $20 \mathrm{~km}$ (Metz, 1973; 1976; Wölfler et al. 2008) instead of $33 \mathrm{~km}$ (Linzer et al. 2002), the Lavanttal Fault is retro-deformed by $15 \mathrm{~km}$ (Kurz et al., 2011) instead of $20 \mathrm{~km}$ (Linzer et al., 2002), the Inntal Fault is retro-deformed applying a displacement of $40 \mathrm{~km}$ (Ortner et al. 2006) instead of $50 \mathrm{~km}$ (Linzer et al. 2002). The sinistral DAV (Defereggen-Antholz-Vals) Fault (Fig. 2) is not taken into account by the retro-deformation of figure 20 because the amount of lateral displacement accommodated by this fault is not constrained. Therefore, the inferred amount of orogen-parallel extension shown in figure 20 is underestimated. Late Oligocene to Early Miocene shortening north of the Northern Calcareous Alps is also not taken into account by the retrodeformation of figure 20 , hence underestimating the bulk amount of shortenin by some $50 \mathrm{~km}$ (Beidinger and Decker, 2014). The sequence of steps shown in figure 20 does not correspond to a chronological 
sequence of deformation events. It only depicts the amounts of retrodeformation in the northern and southern parts of the map separately, for the sake of clarity and to show the different effects of retrodeformation along the ZDWF Fault as in Scharf et al. (2013) or along the Iseltal Fault as in Linzer et al. (2002). The margins of the Tauern Window are shown as stippled line. This area cannot be treated as a rigid block, because it accommodated significant internal deformation.

Figures 20 and 21 show that the maximum east-west extension attained by the Eastern Alps during Oligo-Miocene collision is of $\sim 85 \mathrm{~km}$, in the Northern Calcareous Alps, $\sim 50 \mathrm{~km}$ in the central part of the Eastern Alps and $\sim 45 \mathrm{~km}$ in the southern part of the Eastern Alps. These amounts of orogen-parallel extension are accommodated both by strike-slip displacements, and by normal faults. The stippled area covering the present-day shape of the Tauern Window in figures 20c,d, represents an overlap between different tectonic blocks, which represents extension that was accommodated by normal faulting. This E-W extension amounts to $\sim 45 \mathrm{~km}$, that were probably accommodated along the Brenner Fault, the Katschberg Fault, and more widely distributed between them.

The amount of N-S shortening is of $\sim 75 \mathrm{~km}$ in the western Eastern Alps (north of the indenter corner) and it decreases to $\sim 30 \mathrm{~km}$ in the easternmost part of the eastern Alps (Figs. 20c,d). These amounts of orogen-perpendicular shortening were accommodated both by strike-slip displacements and by thickening (upright folding). Large "gaps" (shown as gray areas in figure 21), corresponding to areas of shortening (thickening), appear immediately north of the indenter corner in the retrodeformed maps, as shown previously (Linzer et al., 2002). The largest gaps, attaining $\sim 55 \mathrm{~km}$ of north-south extension in map-view, are located immediately north and south of the Tauern Window. This suggests that $55 \mathrm{~km}$ out of 
approximately $75 \mathrm{~km}$ of shortening were accommodated by upright folding in the Tauern Window. This value is consistent with previous calculations of shortening by independent methods (Rosenberg et al., 2015). The extent of these gaps, hence of shortening, increases from the eastern to the western Tauern Window (Fig. 21), corroborating previous, independent assessments of an eastward decrease of shortening within the Tauern Window (Schmid et al., 2013; Rosenberg et al., 2015).

After restoration the northwestern corner of the indenter is located almost $70 \mathrm{~km}$ southwestward of its present position (Figs. 20). Therefore, both the amount and the orientation of displacement are consistent with those inferred for the Giudicarie Fault System (Fig. 2), based on the offset of the Periadriatic Fault in map view. We emphasize that no displacement of the Giudicarie Fault System was included in the retrodeformation of figure 20 , hence the latter displacement is a result and not an input of the kinematic reconstruction.

Because retro-deformation as performed in figure 21 does not allow the rotation of blocks nor their internal deformation, the southern margin of the Austroalpine is highly irregular, but its envelope does show a nearly east-west orientation (Fig. 21) in contrast to the present-day state. As a consequence, a clockwise rotation of the Dolomites Indenter took place during collision.

The above retro-deformation was performed keeping the length and orientation of the faults constant. However, analog experiments (movie 1, and Ratschbacher et al., 1991; Rosenberg et al., 2007) show that part of the sinistral faults forming the northern boundary of the eastward extruding wedge change their orientation during indentation, from NE-SW to E-W. If faults rotate towards the plane of flattening (indenter margin), hence if part of their displacement took place 
when they were oriented at higher angle to the indenter margin, the total amount of calculated extension is smaller.

Previous models of retro-deformation along strike-slip faults of the Eastern Alps suggested that orogen-parallel extension accommodated some $170 \mathrm{~km}$ (Frisch et al., 1998), or $120 \mathrm{~km}$ (Linzer et al., 2002), or $70 \mathrm{~km}$ (Rosenberg et al., 2007). The latter value was corroborated by Favaro et al. (2017). The present work shows that orogen-parallel extension varies between $45 \mathrm{~km}$ immediately north of the indenter margin to $85 \mathrm{~km}$ in the North Calcareous Alps (Fig. 20). N-S shortening corresponds to $70 \mathrm{~km}$ and $41 \%$ in the western Eastern Alps. Orogen-parallel extension varies from 45 to $85 \mathrm{~km}$ corresponding to an average of $17 \%$. If the indenter displacement was oriented nearly N-S (Rosenberg et al., 2007), it can account for $\sim 60 \mathrm{~km}$ out of the bulk $75 \mathrm{~km}$ of shortening.

If the northwestern margin of the tectonic map, North of the Subalpine Molasse is considered as fixed, a finite displacement field can be defined by joining marker points between their inferred positions in the very initial stage of collision and their final, present-day position (Fig. 20). These displacement vectors are oriented NNE in the area of the Tauern Window and rotate ENE further east, indicating a component of east-west extension within the orogenic wedge. However, the latter pattern only results from restoration of strike-slip displacements, ignoring shortening that took place north of the North Calcareous Alps. If shortening of the Molasse Basin (Beidinger and Decker, 2014; Ortner et al. 2015) were taken into account, displacement vectors calculated for an area including the northern front of the Alps would be more strongly directed towards the north.

The vector length decreases northward, in the area corresponding to the Northern Calcareous Alps, implying that shortening was accommodated further 
south, mainly in area of the Tauern Window. Interestingly, a rotation of displacement vectors from NNE in the west to ENE in the east is also inferred from present-day GPS measurements and their interpolation (Métois et al., 2015).

\section{VIII.3 Particle paths and cooling during exhumation of the western Tauern Window}

Most exhumation models of the western Tauern Window (Axen et al., 1995; Fügenschuh et al., 1997; 2012; Frisch et al., 1998) tacitly assumed that particle paths during exhumation were parallel to the fault plane, and to the WSW-plunging stretching lineations of the Brenner Mylonites. Alternatively, NNW-SSE oriented displacement paths, sub-parallel to the inferred maximum shortening direction in the footwall of the Brenner Fault, were claimed to control exhumation of the western Tauern Window (Rosenberg and Garcia, 2012). In the latter model, particle paths would deviate upward from the low-angle orientation of the fault plane and cross the fault plane itself, eventually attaining the surface by erosion (Fig. 10).

Analogue experiments simulating indentation of a rigid body with a shape similar to the Dolomites Indenter into a rheologically-stratified lithosphere (Rosenberg et al., 2007), showed that significant orogen-parallel extension can affect the area immediately in front of the indenter corner, hence, in a position analogous to that of the Brenner Fault, even if particle paths are oriented subparallel, and not perpendicular to the convergence direction (Fig. 18c; movie 1).

The occurrence of an almost completely unfolded hanging-wall at the presentday surface, as evidenced by the sub-horizontal orientation of the Creataceous nappes west of the Brenner Fault (Fig. 7b), suggests that the European Basement and the ocean-derived nappes below the Austroalpine hanging-wall are not folded. Therefore, the upright folds exposed in the western Tauern Window were not formed west of the Brenner Fault trace (see cross-sections of Prey, 1980 for a 
similar interpretation) and were not passively translated from west to east below the Brenner Fault plane. If it is taken into account that particle paths east of the Brenner Fault did cut across the mylonitic belt, i.e. they were not parallel to the fault plane, vertical offsets along the Brenner Fault (Fig. 12) cannot be taken as a measure of fault-parallel displacement, which would otherwise be largely overestimated. Whichever proportion of orogen-parallel vs. orogen-perpendicular displacement is inferred, the folded stack of European basement nappes, which could not have formed without contemporaneous exhumation of its upper part, certainly results from top-to-the-North thrusting (e.g., Behrmann, 1990; Lammerer et al., 2008; Schmid et al., 2013), hence, from north- and upward-directed displacement vectors.

\section{VIII.4. II How large is extensional displacement along the Brenner Fault?}

Some exhumation models, interpreted the Tauern Window as an extensional, metamorphic core complex, formed in a pure extensional (Frisch et al., 2000) or transtensional setting (Genser and Neubauer, 1989), post-dating crustal thickening (Neubauer et al., 1999). However, most authors mentioned that shortening accommodated by folding occurred at the same time as orogen-parallel extension both at the western margin (Behrmann, 1988; Selverstone, 1988; Fügenschuh et al., 1997; 2012; Axen et al., 1998; Rosenberg and Garcia, 2011; Schmid et al., 2013; Favaro et al., 2017) and at the eastern margin (Scharf et al., 2013a) of the window. In spite of this consideration, nearly all studies calculated extensional displacement ignoring the contribution of folding and erosion to exhumation. The amount of extension was merely determined by calculating the fault-parallel displacement needed to match the maximum possible vertical offset estimated between footwall and hanging-wall (Axen et al., 1995; Fügenschuh et al., 1997; 2012). Assuming $a$ priori that the present-day orientation of the Brenner Mylonites reflects the 
orientation of the fault plane throughout exhumation, horizontal extensional

displacements (Table II) were inferred to be as large as $63 \mathrm{~km}$ (Axen et al., 1995), $>70 \mathrm{~km}$ (Fügenschuh et al., 1997), or $>44 \mathrm{~km}$ assuming that part of this displacement took place along a steeper, brittle fault plane (Fügenschuh et al., 2012).

\begin{tabular}{|c|c|c|}
\hline Authors & $\begin{array}{c}\text { Amount of horizontal extension } \\
\text { (heave) }\end{array}$ & $\begin{array}{l}\text { Argument supporting the calculated amounts of } \\
\text { extension }\end{array}$ \\
\hline Behrmann, 1988 & $11.5-18.5 \mathrm{~km}$ & $\begin{array}{l}\text { Based on an estimated throw of } 5-8 \mathrm{~km} \text {, an average } \\
\text { dip of } 25^{\circ} \text { for the Brenner mylonites, and assuming } \\
\text { that the entire vertical offset was exclusively } \\
\text { accommodated along the Brenner mylonites }\end{array}$ \\
\hline Selverstone, 1988 & $\begin{array}{l}\text { Several } \mathrm{km} \text { to tens of } \mathrm{km} \text {. } \\
\text { Quoted as } 10-20 \mathrm{~km} \text { in Axen et } \\
\text { al., } 1995\end{array}$ & Based on an estimated throw of $10 \mathrm{~km}$ \\
\hline $\begin{array}{l}\text { Selverstone et al., } \\
1995\end{array}$ & & $\begin{array}{l}\text { Based on the estimated vertical distance of } 15 \mathrm{~km} \\
\text { between the two inferred rolling hinges, assuming } \\
\text { an average fault dip of } 30 \text { to } 45^{\circ} \text {, and adding } 10 \mathrm{~km} \\
\text { horizontal distance, which correspond to the extent } \\
\text { of E-down faults in map view, exposed east of the } \\
\text { Brenner trace. }\end{array}$ \\
\hline Axen et al., 1995 & $33-63 \mathrm{~km}$ & $\begin{array}{l}\text { Based on a rolling-hinge model for the Brenner } \\
\text { Fault, with an average dip of the Brenner mylonites } \\
\text { of } 20^{\circ} \text {, and a depth of the lower rolling hinge } \\
\text { between } 12 \text { and } 23 \mathrm{~km} \text {. }\end{array}$ \\
\hline $\begin{array}{l}\text { Fügenschuh et al., } \\
1997\end{array}$ & $50->70 \mathrm{~km}$ & $\begin{array}{l}\text { Based on an estimated throw of } 20 \mathrm{~km} \text {, an average } \\
\text { dip of } 15^{\circ} \text { for the Brenner mylonites, and assuming } \\
\text { that the entire vertical offset was exclusively } \\
\text { accommodated along the Brenner mylonites }\end{array}$ \\
\hline Frisch et al., 2000 & $\begin{array}{l}160 \mathrm{~km} \text {, including extension } \\
\text { along the Katschberg Fault }\end{array}$ & $\begin{array}{l}\text { Assuming the entire E-W length of the Tauern } \\
\text { Window in map view resulted only from extension } \\
\text { along the Brenner and Katschberg Faults }\end{array}$ \\
\hline $\begin{array}{l}\text { Rosenberg and } \\
\text { Garcia, } 2011\end{array}$ & $2-14 \mathrm{~km}$ & $\begin{array}{l}\text { Assuming that the amplitude of the Tauern upright } \\
\text { antiformal structure ( }>10 \mathrm{~km}) \text { accommodated } 10 \\
\mathrm{~km} \text { of the bulk throw of } 15 \mathrm{~km} \text { and only the } \\
\text { remaining } 5 \mathrm{~km} \text { resulted from extensional } \\
\text { displacement, accommodated partly along the } \\
\text { Brenner mylonites and partly along a steeper, } \\
\text { brittle fault. }\end{array}$ \\
\hline
\end{tabular}




\begin{tabular}{|l|l|l|}
\hline $\begin{array}{l}\text { Fügenschuh et al., } \\
2012\end{array}$ & $44 \mathrm{~km}$ & $\begin{array}{l}\text { Based on an estimated throw of } 17 \mathrm{~km}, \text { that } \\
\text { entirely resulted from extension, accommodated } \\
\text { along 1) the Brenner mylonites with an average dip } \\
\left.\text { of } 17^{\circ} \text { for for } 12 \mathrm{~km} \text { of the bulk throw; } 2\right) \text { Brittle part } \\
\text { of the Brenner Fault with average dip of } 45^{\circ} \text { for the } \\
\text { remaining } 5 \mathrm{~km} \text { of the bulk throw. }\end{array}$ \\
\hline $\begin{array}{l}\text { Rosenberg and } \\
\text { Garcia, } 2012\end{array}$ & $2-14 \mathrm{~km}$ & Same argument as Rosenberg and Garcia (2011) \\
\hline
\end{tabular}

Table II. Review of inferred amounts of extension accommodated along the Brenner Fault.

Recently, two different approaches were used to evaluate the distinct contribution of folding and erosion to the bulk amount of exhumation. Rosenberg and Garcia (2012) estimated that the maximum amount of exhumation resulting from folding and erosion corresponds to the difference in elevation between structural markers located in the reconstructed hinge of the eroded, upright antiform and the same markers, lying in a sub-horizontal orientation, to the north and west of the antiform. This difference in elevation being approximately $10 \mathrm{~km}$, it was concluded that $10 \mathrm{~km}$ of vertical offset were accommodated by folding and erosion, hence, the remaining $5 \mathrm{~km}$ of vertical offset should be accommodated by extension (Rosenberg and Garcia, 2012). The second approach (Fügenschuh et al., 2012) considered that the entire vertical offset (estimated to $17 \mathrm{~km}$ ) resulted from extensional displacement that was calculated to be of $44 \mathrm{~km}$ based on the dip angles of the Brenner Mylonites and the brittle Silltal Fault. Only the difference between the inferred pre-extensional depth of the footwall $(21 \mathrm{~km})$ as derived from metamorphic pressure and the vertical offset along the Brenner Fault (17 km), i.e., 4 $\mathrm{km}$, were interpreted to result from folding and erosion. 
We consider that the first approach is more likely for the following reasons: 1) it does not assume a priori extension or folding, but uses the reconstructed geometry of the folds in cross section to constrain the amount of exhumation by folding. Cross sections do show that any structural marker in the hinge of the antiform is located $\sim 10 \mathrm{~km}$ higher than in the most external part of the limb of the same fold (Figs. 4 and 6). Extensional denudation does not result in a characteristic geometry that could allow for the quantification of its displacement. 2) The second approach depends on the knowledge of the progressive strain history, in particular the rotation of the fault plane during progressive deformation as generally assessed for extensional faults (e.g., Buck, 1988; Wernicke and Axen, 1988); 3) the results of the second approach, constraining $4 \mathrm{~km}$ of exhumation by folding and erosion is in contrast with the reconstructed amplitude of $10 \mathrm{~km}$ of the folds. Erosion in the hinge of the antiform eliminated a vertical length of $\sim 10 \mathrm{~km}$ in excess of the background erosion level adjacent to the fold (Fig. 6c); 4) cross sections constructed by projection of hanging-wall structures do show that the entire footwall of the Brenner Fault is folded with the same geometry of the cross sections constructed by projecting footwall structures (Fig. 11). In both cases exhumation of the deepest units is located in the axial region of these folds. The nearly horizontal orientation of the mylonitic belt in cross section cannot explain why exhumation of its footwall is higher in the fold hinges. Hence, both cross sections of figure 11 show that it is the fold geometry that always controls the amount of exhumation. This control is also shown by the along-strike asymmetry of the vertical offset. Where fold limbs dip steeply and are partly overturned, the along-strike change of vertical offset is more abrupt (from 0 to $17 \mathrm{~km}$ along a horizontal distance of $17 \mathrm{~km}$ in the southern limb; 
Fig. 12), and where the fold limb dips gently, the vertical offset varies more gently (13 km along a distance of $35 \mathrm{~km}$ in the northern limb; Fig. 12).
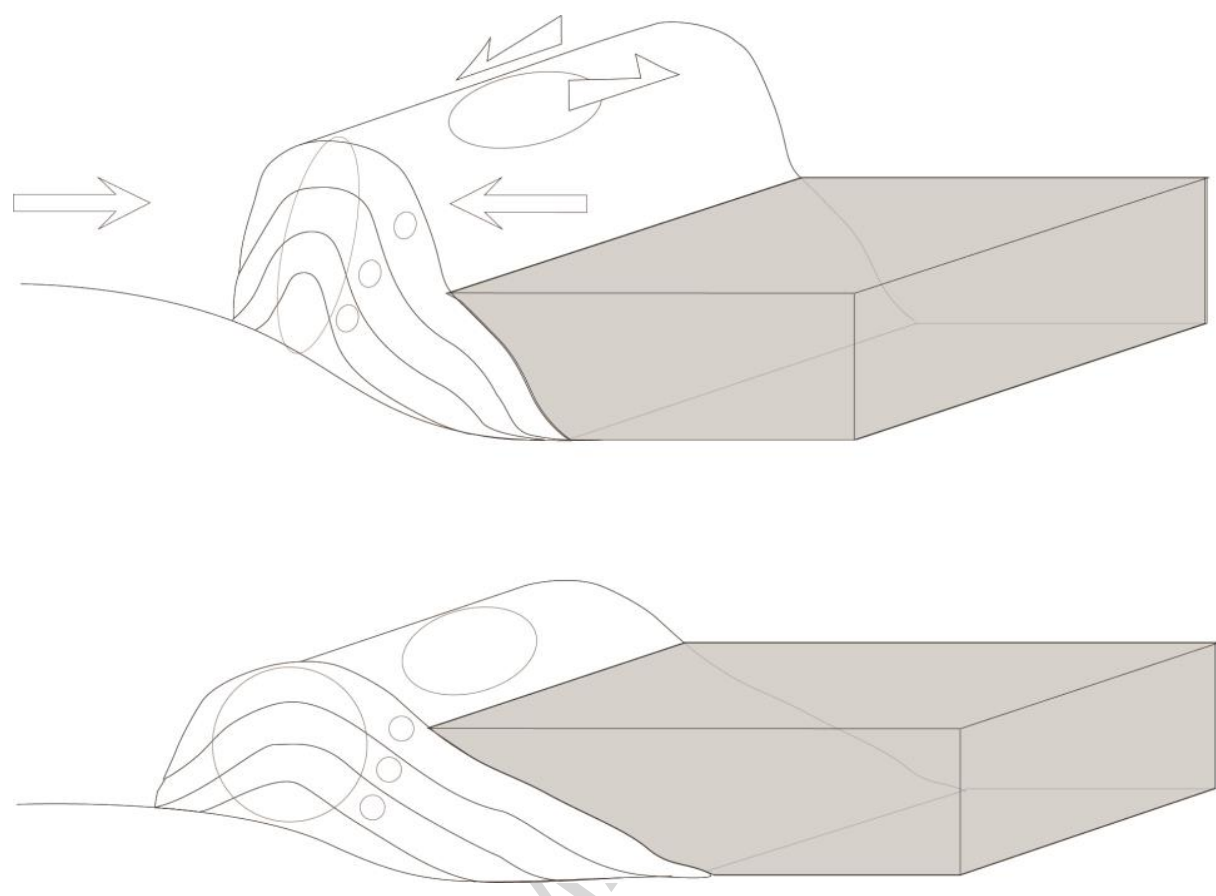

Fig. 22. Schematic diagram showing orientation and aspect ratios of deformation ellipsoids during two stages of folding of a nappe stack. Smaller circles and ellipses point to deformation on the outcrop scale, whereas the larger ones point to deformation on the scale of the collisional wedge. Lower figure: nappe stack (white) in front of an indenter (gray). Undeformed strain markers (circles) are shown on the nappe stack, to illustrate the postnappe deformation in the upper figure. Upper figure: geometry of strain markers and nappes after shortening of the nappe stack by folding. Note that large vertical stretching and horizontal shortening are accommodated on the scale of the entire nappe stack, although they are not expressed in the more local deformation ellipsoids, hence fabrics.

Different large-scale observations do suggest that extensional displacements along the Brenner Fault may not have been very large. If the vertical throw of $>17$ resulted from extensional unroofing, crustal thinning of a similar amount should be easily detected by geophysical methods at depth. However, Moho maps do not show any deflection below the Brenner Fault (Figs. 1 and 2; Rosenberg and Garcia, 2011; 
Spada et al., 2013). In contrast, if 10 out of the $17 \mathrm{~km}$ of vertical offset resulted from an-along strike differential thickening due to folding that was then eroded to one and the same surface level, no changes of the Moho depth would be expected.

Stretching lineations in the western sub-dome strike ENE, sub-parallel to fold axes (Fig. 8; Axen et al., 2005; Schneider, 2014). This may suggest that the longest axis of the deformation ellipsoid was nearly horizontal during collision and exhumation, and not sub-vertical as could be expected if exhumation was accommodated mainly by upright folding and erosion. However, the orientation of the stretching lineations may not reflect the orientation of the maximum extensional direction, if part of the extension was accommodated by buckling of the nappe pile. As sketched in figure 22, if shortening is largely accommodated by buckling of the nappe pile, large part of the vertical extension is accommodated by the rotation of the fold limbs into a steep orientation without significantly deforming the interior of the nappes. In this case the fabric of the rocks on the outcrop scale may not show significant elongation in the vertical direction, although the latter represents the major extensional direction on the larger scale (Fig. 22), as shown by the amplitude of upright folds in cross sections (Fig. 6). East-west extension undoubtedly occurred during upright folding, but the maximum extensional direction may have been vertical.

VIII.5. How large is extensional displacement along the Katschberg Fault?

Extensional displacement along the Katschberg Fault was first inferred to accommodate $16.5 \mathrm{~km}$ of displacement (Genser and Neubauer, 1989), and recently re-evaluated to $26 \mathrm{~km}$ (Scharf et al., 2013a). The first interpretation was based on the inferred jump in metamorphic temperature from footwall to hanging-wall, 
whereas the latter was based on the inferred tectono-stratigraphic omission of 13.5 $\mathrm{km}$ along the southern part of the KSZS (Scharf et al., 2013a), where the deepest unit of the Venediger Duplex is exposed. Considering a priori that exhumation resulted from extensional un-roofing and taking an average dip angle of $25-30^{\circ}$ of the mylonites as the constant orientation of the fault plane throughout its activity, the maximum vertical offset along the KSZS corresponds to $23-29 \mathrm{~km}$ of horizontal displacement (Scharf et al., 2013a). However, if an angle of $40^{\circ}$ is taken, as suggested by the geometrical relationships described above and shown in figures 13 and 14, still assuming a fault-parallel exhumation path, and a purely extensional denudation process, a value of $16 \mathrm{~km}$ of east-west extension results for the area of maximum vertical offset.

Upright folding and erosion certainly contributed to exhumation, as suggested by the coincidence between the area of maximum vertical offset and the hinge of the upright fold that folds the footwall (Figs. 3a and 12). Parts of the eastern sub-dome, namely the Glockner and Matreier nappes, lie outside of the KSZS, north of its dextral branch (Figs. 2 and 3a; Scharf et al., 2013b). These units form the northern limb of the eastern sub-dome and are overprinted by regional metamorphism whose maximum $\mathrm{T}$ increases from $325{ }^{\circ} \mathrm{C}$ immediately south of the SEMP Fault to $450{ }^{\circ} \mathrm{C}$ along the northern branch of the KSZS, as shown by Raman Spectroscopy of Carbonaceous Material (Fig. 9a; Scharf et al., 2013b). This part of the eastern sub-dome dips gently below the Austroalpine, but turns into a subvertical orientation near the SEMP Fault and is not bounded by extensional faults along its eastern boundary. Hence, exhumation of Cenozoic, metamorphic rocks with $\mathrm{T}$ attaining $450^{\circ} \mathrm{C}$ in this part of the Tauern Dome, must have occurred by folding and erosion. 


\section{VIII.6. Oligo-Miocene kinematics}

The different orientation of the long axes of the western and the eastern subdome intrigued numerous tectonic studies, and it was proposed that the orientation of the eastern sub-dome resulted from ongoing convergence of the Dolomites Indenter (e.g., Tollman, 1980). Polinski and Eisbacher (1992) suggested a temporal and kinematic link between the sinistral Giudicarie Fault System, hence, the Dolomites Indenter, and the sinistral shear zones of the western Tauern Window (Fig. 3a). In their model the dextral Mölltal, Hochstuhl, and Lavanttal Faults formed in the Neogene, after the inferred Paleogene activity of the sinistral SEMP and Giudicarie faults. Considering sinistral displacements along NE-striking faults compatible with NE-SW oriented shortening, the age of the latter faults was inferred to be Paleogene (Polinski and Eisbacher, 1992) by analogy with NE-SW oriented shortening in the Southern Alps (Doglioni, 1987; Doglioni and Bosellini, 1987). This idea, of two temporally separate events affecting the western and eastern structures of the Tauern Window inspired later conceptual models suggesting that the dextral strike-slip systems were younger than the sinistral ones, which are inferred to be of Late Oligocene age (Neubauer et al., 1999; Mancktelow et al., 2001). However, analogue models, showed that both sub-domes, could form at the same time during a single phase of shortening (Fig. 18; Rosenberg et al., 2004; 2007), with deformation localizing along conjugate thrust systems in the upper crust, and passing into upright folds in the lower crust, whose orientation is subparallel to the one of the thrusts (Fig. 18; and movie 1). Therefore, even the eastern sub-dome, which strikes at a high angle to the Giudicarie Fault System, most probably resulted from the same indentation event, which created the western sub-dome. Indeed, the 
displacement field of figure 21, resulting from the combined sets of dextral and sinistral faults, is perfectly compatible with the inferred sinistral displacement of 70 km (Schönborn, 1992) along the NNE-striking Giudicarie Fault System.

The amount of post-Oligocene shortening was inferred to be nearly constant through-out the Eastern Alps (Linzer et al., 2002), varying between a minimum of $61 \mathrm{~km}$ west of the Tauern Window, to $64 \mathrm{~km}$ across the Tauern Window and $64 \mathrm{~km}$ at the eastern margin of the Eastern Alps. Their restoration shows that the east-west extent of the area corresponding to the Tauern Window was only $50 \mathrm{~km}$ during the Oligocene, that the Northern Calcareous Alps were stretched in east-west direction by $22 \%(\sim 90 \mathrm{~km})$, and that little deformation affected the Austroalpine Basement east of the Tauern Window. However, our retrodeformation to the pre-Oligocene state (Fig. 20) shows that the east-west length of the area corresponding to the present-day Tauern Window has only been increased by some $45 \mathrm{~km}$, whereas its north-south extension must have been $55 \mathrm{~km}$ larger in the west, and 20-40 km larger in the east. These data are in better agreement with recent estimates of shortening in the Subalpine Molasse (Ortner et al., 2015). East of the Tauern Window, as previously shown by Linzer et al. (2002), shortening localizes immediately in front of the Dolomites Indenter (gray areas in Fig. 21). On the first order, a map-view distribution of areas affected by shortening and extension analogous to the one of figure 21 may be obtained by 2D, schematic models of blocks sliding along NE-striking sinistral faults in the north and SE-striking dextral faults in the south (Fig. 23). Such a spatial pattern of strike-slip faults is well documented in the Eastern Alps (e.g., Ratschbacher et al., 1991b; Linzer et al., 2002) and was inferred to govern the large-scale pattern of collisional deformation (Ratschbacher et al., 1991b). 


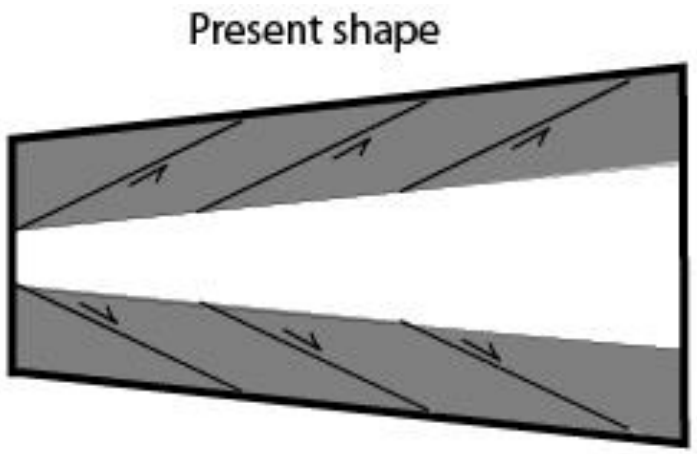

Retro-deformed
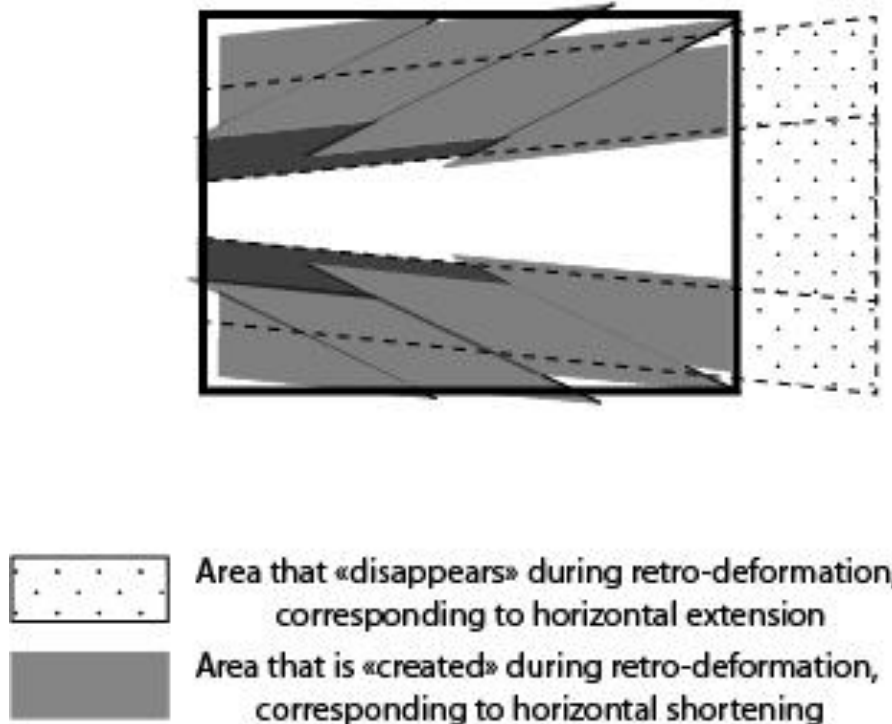

Area that «disappears» during retro-deformation, corresponding to horizontal extension

Area that is screated during retro-deformation, corresponding to horizontal shortening

Fig. 23. Schematic sketch illustrating the change of geometry in map view of E-W extension accommodated by a conjugate system of en échelon strike-slip faults whose shear sense is sinistral in the north and dextral in the south. Note the area increase in the western part of the box and the decrease in the east, corresponding respectively to shortening and extension. For any given displacement, if the orientation of the faults is at higher angle to the extrusion direction, the "gap" in the western area (hence the amount of collisional shortening) increases and the southernmost boundary rotates by a higher angle, thus attaining an E-W orientation.

Figure 23 shows that the activity of the above described conjugate sets of strike-slip faults leads to an area increase in the west and an area decrease in the east of the retro-deformed body, hence, a transition from shortening in the west to extension in the east, as previously described by Ratschbacher et al. (1991b). Therefore, in spite of its schematic character and simplicity, this kinematic model 
(Fig. 23) explains the transition from a thickened (present-day Moho up to $52 \mathrm{~km}$ depth; Fig. 2) and shortened area in the Tauern Window, to a thinner and extended area east of the Tauern Window (present-day Moho at 32 to $36 \mathrm{~km}$ depth; Figs. 1 and 2). The western part of the deforming model acts as a source of material that is transferred to the ENE and ESE during bulk north-south shortening. During retrodeformation the fault-blocks are slid backwards to the WSW and WNW, thereby increasing the north-south extension in map-view. In order to reduce this large space during forward deformation significant north-south shortening needs to take place in the west.

The model above also illustrates some of the other first-order tectonic characteristics of the Cenozoic Eastern Alps. Retro-deformation of the strike-slip faults within the wedge-shaped body analogous to the present-day map view of the Eastern Alps, transforms this wedge into a rectangle with E-W-striking margins both in the south and the north. Hence the southern margin, that is analogous to the northern boundary of the Dolomites Indenter, is affected by a clockwise rotation during the activity of the strike-slip faults. In the restored maps of figures 20 and 21 the indenter margin, acquires an orientation that is close to east-west (N95E), suggesting a clockwise rotation of $5^{\circ}$ of the indenter during collision. Independently of the model above, such rotation was postulated (Bertrand et al., 2015) to explain along-strike gradients of shortening in the Tauern Window (Schmid et al., 2013; Rosenberg et al., 2015). The retrodeformed east-west strike of the Periadriatic Fault is similar to its westward continuation, west of the Giudicarie Fault System (Fig. 2).

The easternmost area of the model in figure 23 shows the closing of a space in the retro-deformed map, hence, the occurrence of an area of Cenozoic extension. Such an area is not known from the Eastern Alps, except for its small Miocene pull- 
apart basins (Sachsenhofer et al., 2000) along the Lavanttal and the Mur-Mürz faults (Fig. 2) and it does not appear to exist in figure 18a. This is due to the fact that extension, which is required to maintain strain compatibility of a strike-slip model as in figure 23, takes place within the Styrian- (e.g., Neubauer and Genser, 1990) and the Vienna basins, but these are not shown in figure 21.

The regional distribution of the areas of shortening described above are consistent with those forming during the indentation experiment illustrated in figure 18 and Movie 1. As shown by the flattened and stretched strain ellipses (Fig. 18d) the area of maximum shortening corresponds to the Tauern Window, and from there it bifurcates eastward, in a belt adjacent to the indenter margin, and one that strikes along the SEMP Fault.

\section{VIII.7. Geodynamic causes of orogen-parallel extension}

Different geodynamic significance was attributed to orogen-parallel extension in the Eastern Alps. Irrespective of the absolute amount of extension attributed to the Brenner and to the Katschberg faults, the origin of this orogenparallel extension is interpreted in different ways. Some models related it to largescale, plate tectonic processes, situated outside of the Tauern Window, as the roll back of the Carpathian subduction zone (Sperner et al., 2002), or the lateral escape of the orogenic wedge, thus accommodating indentation of the Southern Alps (Ratschbacher et al., 1991b; Linzer et al., 2002). Other interpretations considered that orogen-parallel extension resulted partly (Ratschbacher et al., 1991b) or entirely (Neubauer et al., 1999) from the gravity-driven collapse of thickened orogenic crust. 


\section{a. Indentation-induced lateral extrusion}

Orogen-parallel extension in the Eastern Alps is generally attributed to "lateral extrusion", that was described as the combination of gravitational collapse and lateral escape (Ratschbacher et al., 1991a, b). This model is based on the interpretation of the Cenozoic fault pattern and on analogue experiments of indentation, which paradoxically show that it is physically very difficult to obtain large amounts of east-directed displacements by indentation.

Retrodeformation performed along the major strik-slip faults (Fig. 20), shows that the Eastern Alps as a whole become shortened in north-south direction and stretched in east-west direction accommodating a deformation that is dominated by NE-directed displacement vectors in the west and ENE in the east (Fig. 21). This transition resulted into a gradient of crustal thickening, increasing westward, associated to an eastward decrease of average elevation. The topographic gradient is strongest across the area of the Katschberg Fault (Fig. 1; Frisch et al., 1998) and it may have driven orogen-parallel lower crustal flow, facilitated by the inferred high geothermal gradients affecting the Miocene collisional wedge (Sachsenhofer, 2001).

The present-day velocity field, based on GPS observations (e.g., Métois et al., 2015) shows that the E- to NE-directed displacement vectors in the Eastern Alps are not restricted to the wedge between the SEMP and the Periadriatic Fault, but continue to the northernmost deformation front of the Alps, and even further North, in the Molasse Basin and Bohemian Massif. The latter study shows that calculated gradients of potential energy that could drive lateral extrusion do not correlate with topographic gradients, therefore suggesting that the cause of eastward displacements may be a deeper-seated, motion of the mantle. 
In spite of the latter conclusions regarding the present-day kinematics of the Eastern Alps, the eastern termination of the antiformal stack of the Tauern Window in the "middle" of the Eastern Alps, close to the latitude of $14^{\circ}$, separates two areas of the chain whose amount of thickening was very different. Although large parts of the thickened wedge of the Tauern Window are eroded (Fig. 6), the topography and the Moho, respectively increase and deepen from east to west across the latter boundary (Fig. 1). Therefore, a large gradient of gravitational potential energy still exists (Métois et al., 2015). The occurrence of Barrovian metamorphism in the Tauern Window must have induced a change in rheology between the western and eastern parts of the Eastern Alps during the Miocene. This change coupled with the aforementioned gradient in gravitational potential energy may have driven orogenparallel extension.

\section{b. Extension in front of indenter corners}

Many similarities exist between the Brenner Fault in the Eastern Alps and the Simplon Fault at the boundary between Central and Western Alps (Selverstone, 1988; Mancktelow and Pavlis, 1994). These similarities are manifested by the orientation of the faults perpendicular to the strike of the orogen, by the accommodation of orogen-parallel extension throughout the Miocene (Keller et al., 2006; Bertrand et al., 2017), by the spatial coincidence between the faults and the site of maximum shortening of the thickened lower plate (Rosenberg et al., 2015), and by the more pronounced shortening of the footwall compared to the hangingwall. In this respect however, the hanging-wall of the Brenner Fault is gently dipping and not folded (Fig. 7b), not folded, whereas the hanging-wall of the Simplon Fault is folded, albeit less than its footwall. Finally, both faults depart from the corner of a 
South-Alpine Indenter. These analogies suggest that the nucleation and growth of both faults stems from the same cause, which is the displacement of an indenter corner. Indeed, all existing analogue, indentation models, showing the deformation field in front of indenter corners (e.g., Lu and Malavieille, 1994; Zweigel, 1998; Lickorish et al. 2004; Rosenberg et al., 2004, 2007; Reiter et al., 2011; Luth et al., 2013), do show the occurrence of a local deviation with respect to the remaining displacement field of the deforming plate (Fig. 18c). If the dimensions of the indenter depicted in Fig. 18d are scaled to the Eastern Alps, horizontal extension in the horizontal plane attains more than $20 \mathrm{~km}$ in front of the indenter corner. Whereas material particles move in a direction close to that of the indenter itself in front of the straight segment of the indenter boundary, they diverge from each other in front of the indenter corner (Fig. 18c) causing orogen-parallel extension. Hence, displacement of the indenter corner is one cause of orogen-parallel extension in the collisional wedge. However, it cannot explain orogen-parallel extension throughout the Eastern Alpine collisional wedge, away from its specific location, hence that of the Brenner Fault.

\section{c. Carpathian rollback}

Rollback beneath the Carpathian Arc was shown to control thinning of the Pannonian Basin and the eastward migration of extensional basins (Royden et al., 1982). Some studies suggested that the latter process could trigger orogen-parallel extension even in the Eastern Alps (Ratschbacher et al., 1991b; Sperner et al., 2002), whereas others pointed out on the base of numerical geodynamic models that the distance between the Tauern Window and the Carpathian belt is too large, to allow for the transmission of extensional stresses from the latter to the former area (Robl 
and Stüwe, 2005). In addition, Scharf et al. (2013a) and Schmid et al. (2013) pointed out that rollback in the Carpathians is inferred to be post-20 Ma, based on the age of both sedimentation (Royden, 1982; Horvath, 1995; Matenco and Radivojevic, 2012) and volcanism (Pecskay et al., 2006; Harangi and Lenkey, 2007) in the Pannonian Basin. In contrast, cooling of the Tauern Window starts at $30 \mathrm{Ma}$, implying that rollback beneath the Carpathian Chain could not initiate exhumation of the Tauern Window, but possibly "facilitated its eastward expansion after $17 \mathrm{Ma}$, by weakening its lateral constraint. Indeed, cooling from temperatures $\geq 450{ }^{\circ} \mathrm{C}$ (U-Pb Apatite) down to $250{ }^{\circ} \mathrm{C}$ (FT zircons) took place between 30 and 12 Ma in the Tauern Window (Fig. 15). Hence, large parts of the exhumation (and extension) of the Tauern Window must predate slab-rollback beneath the Carpathians.

VIII.8. Tauern Window vs. the other Penninic windows of the Eastern Alps

Syncollisional exhumation of the Rechnitz Windows (Fig. 2) and the Tauern Window were inferred to result from one and the same geodynamic process (e.g., Frisch et al., 2000). Indeed, cooling ages in the Rechnitz Window and in the Tauern Window are similar, with zircon FT ranging from 22 to $13 \mathrm{Ma}$ and apatites between 7 and 9 Ma (Dunkl and Demeny, 1997). However, the Oligocene structures and kinematics of the Rechnitz Window are completely different from those of the Tauern Window. The Rechnitz Window is located in the Styrian Basin (Fig. 2), i.e., in the westernmost Pannonian Basin. This area is only affected by extensional structures throughout the Miocene and the Moho is shallower, located at $\sim 30 \mathrm{~km}$ depth in this area (Figs. 1 and 2; Spada et al., 2013). In addition, the Moho strikes north-south and dips eastward (Fig. 2; Spada et al., 2013), an orientation that is difficult to reconcile with that of the inferred north-south shortening. In spite of the 
poor outcrop conditions, there is no evidence for shortening of these windows, which lie on a crust that is thinner by one third compared to the present-day one in the Tauern Window. Fold axes are oriented north-south (Cao et al., 2013) as expected for an extensional core complex unroofed by east-west extension. Its formation undoubtedly occurred by extensional denudation, associated to extension of the Pannonian Basin (Dunkl and Demeny, 1997).

\section{VIII.9. The eastern termination of the Eastern Alps}

The eastern termination of the Eastern Alps, i.e., the area located between the Katschberg Fault and the Styrian Basin (Fig. 2) is characterized by progressive eastward thinning of the crust (Behm et al., 2007; Brückl et al., 2010; Molinari et al., 2012; Spada et al., 2013, Figs. 1 and 2), a decrease of elevation (Fig. 1) and a change of strike of the European Moho, which turns into a NNW strike east of the Katschberg Fault (Fig. 2). At present, the lateral change of crustal thickness from the core of the Tauern Window to the western margin of the Styrian Basin corresponds to $70 \mathrm{~m} / \mathrm{km}$ along an E-W section. This value is approximately three times that of the lateral gradient existing at the eastern margin of the Tibetan Plateau (e.g., Shin et al., 2015). Eastward thinning of the crust goes together with a reduction of topography (Fig. 1; Frisch et al., 1998), a trend towards older thermochronological ages (Fig. 5), slower cooling rates (Fig. 16) and an increased preservation of Neogene paleo-topographic surfaces (Tollmann, 1986; Fig. 16). However, these changes are not associated to increased crustal extension accommodated by normal faults. The only extensional faults affecting the area between Tauern Window and Styrian Basin are related to small pull-apart structures along strike-slip faults (e.g., Tamsweg-, Fohnsdorf-, Lavanttal Basins; Fig. 2), which did not accommodate more than a few km of orogen-parallel extension (e.g., Linzer et al., 2002; Wölfler et al., 
2010). These basins are located along conjugated SE-, or NE-striking, dextral and sinistral faults, respectively (Fig. 2). The exposed structural level of the Austroalpine nappe stack is overall the same from the Katschberg Fault to the Styrian Basin, always consisting of Upper Austroalpine Units (Fig. 2). Hence, the eastward decrease of crustal thickness (from 44 to $32 \mathrm{~km}$ ) determined in the latter area is not related to significant changes in the amount of crustal exhumation.

As discussed in section VIII.1. changes of Moho depth are controlled primarily by the thickness of the Cenozoic nappe pile (Figs. 6 and 19). Because the Moho is less than $40 \mathrm{~km}$ deep east of the Lavanttal Fault (Fig. 2) and assuming that the sequence of nappes is similar to the one exposed in the Tauern Window, it is unlikely that the European Basement is thickened and shortened below this part of the Alps. This is consitent with the modest amounts of Miocene exhumation as inferred from preserved Neogene paleotopographic surfaces over wide areas (Fig. 16) and the ages of low-T thermochronometers (FT apatites, Fig. 5b) that are pre- to early collisional.

Based on teleseismic tomography Mitterbauer et al. (2011) documented the transition from a positive to a negative velocity anomaly below the Eastern Alps, at $14^{\circ}-14.5^{\circ}$ latitude. This transition is interpreted to represent the eastern limit of the European Slab (Fig. 24), and the western limit of an area characterized by low velocity anomalies above a deep, oceanic slab (Mitterbauer et al., 2011). If the Katschberg Fault is projected with an angle of $32^{\circ}$ (Figs. 13and 14) down to the base of the crust it nearly overlaps with the limit of the aforementioned positive anomaly at $14^{\circ}-14.5^{\circ}$ latitude, betwen $46^{\circ} 45^{\prime}$ and $47^{\circ} 15^{\prime}$ longitude, as imaged from tomography (Mitterbauer et al., 2011, their figure 7). The absence of such an inferred, continental lithospheric slab (Mitterbauer et al., 2011) below the 
easternmost Eastern Alps, i.e. between the Katschberg Fault and the Styrian Basin, is an independent and additional evidence for the lack of significant orogenperpendicular shortening and crustal thickening in the latter area. However, the differences in cross sectional area between the reconstructed nappe stack in the Tauern Window and the inferred nappe stack east of the Tauern Window (Fig. 19; Prey, 1980) cannot only be explained by increasing amounts of indentation to the west. Such a large-scale, along-strike change may result from a step in the geometry of the European passive margin, inherited from the Jurassic phase of rifting (Fig. 24). This scenario was already proposed to explain the larger accretion of continental basement nappes in the Tauern Window, interpreted to be the cause of Barrovian metamorphism (Goffé et al., 2003).

The idea presented above, suggesting that the Eastern Alps were strongly shortened and thickened in the west and less in the east (Figs. 1, 6, and 19), is consistent with the eastward decrease of sediment thickness in the Molasse Basin (Fig. 16), pointing to an eastward decrease of crustal load. However, changes in the equivalent elastic thickness of the lithosphere (Andeweg and Cloetingh, 1998), possibly inherited from the pre-Alpine extensional structure of the lithosphere, may also influence such along-strike trend.

Thinning of the crust did not take place locally in the area of the Katschberg normal fault as could be expected to result from normal fault activity. Hence the reduced thickness of the eastern Eastern Alps does not result from thinning of an orogenic wedge that resembled that of the Tauern Window. The eastern Eastern Alps were not shortened and thickened to a similar degree as the western Eastern Alps. This conclusion is consistent with the fact that Miocene, metamorphic $\mathrm{T}$ of the oceanic nappes underlying the Austroalpine nappes in the Rechnitz Window never 
attained $400^{\circ} \mathrm{C}$ (Cao et al., 2013), whereas the same units record a metamorphic $\mathrm{T}$ of up to $600^{\circ} \mathrm{C}$ in the Tauern Window (Fig. 9a). Hence, at the eastern end of the Alpine collisional belt, where a continental, lithospheric slab does not seem to be present (Mitterbauer et al., 2011) a reduction of collisional shortening and thickening is observed (Fig. 24; Mitterbauer et al., 2011; Zhao et al., 2016). Alternative interpretations suggest that a continental slab, attached to the Adriatic plate, was subducted below the eastern Eastern Alps, down to almost $250 \mathrm{~km}$ depth (Lippitsch et al., 2003; Schmid et al., 2013, Handy et al., 2015). As shown in figure 24 and interpreted from P-wave tomography (Mitterbauer et al., 2013) we prefer to interpret the deep velocity anomaly of the eastern Eastern Alps as stemming from an oceanic and detached slab. This is justified by the inferred amount of collisional shortening of the eastern Southern Alps, i.e. of the Adriatic Plate, that did not exceed $50 \mathrm{~km}$ (Schönborn, 1999, Nussbaum, 2000) during collision. Subduction of a continental plate to $250 \mathrm{~km}$ depth would require shortening of the crust by a similar amount. 

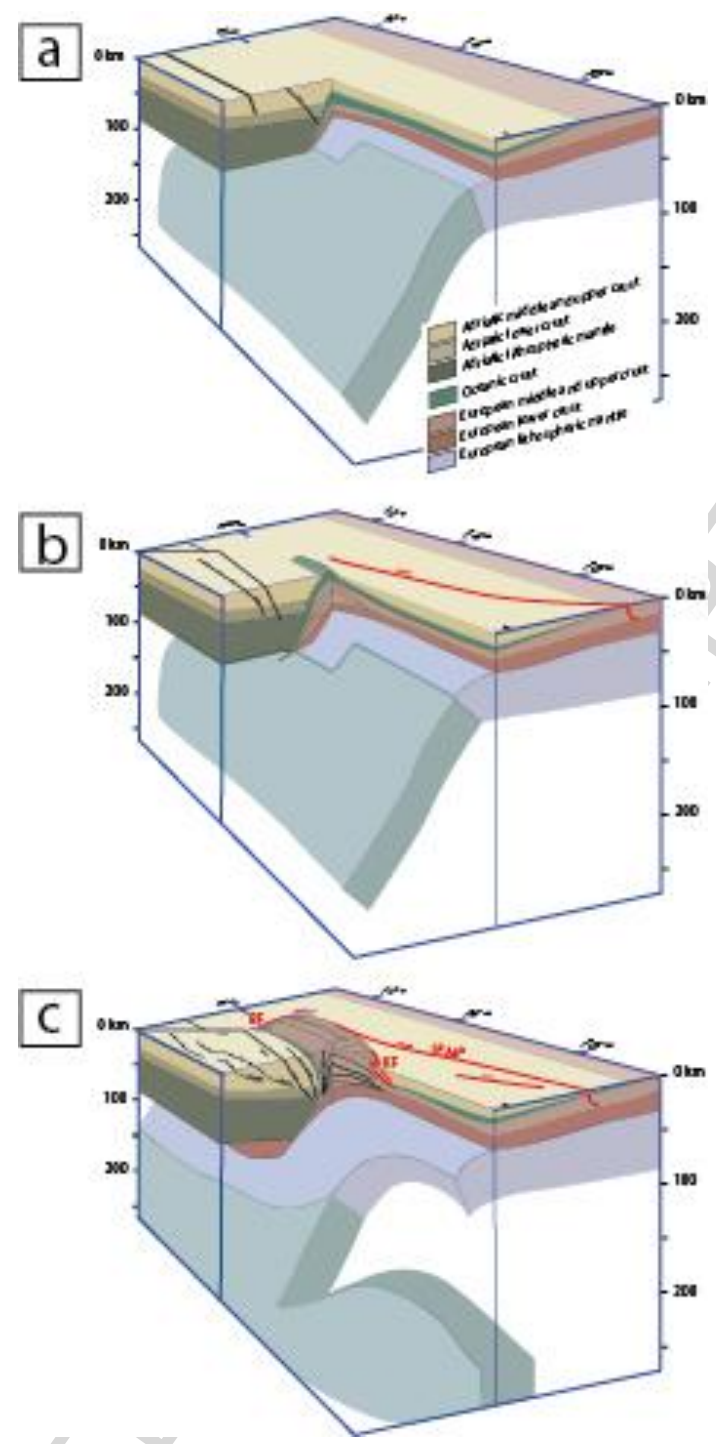

Fig. 24. Schematic, evolutionary 3D diagram of the deep structure of the Eastern Alps. a) Incipient continental subduction of the European Plate in the West passing in an oceanic subduction further East due to an inherited "step" of the European passive margin. b) Continental subduction accommodated by nappe stacking in site of the future Tauern Window. c) Amplification and exhumation of antiformal stack of European basement nappes in the Tauern Window, above the attached European Slab. This slab does not continue east of $14^{\circ}$ longitude and no significant crustal thickening has taken place there during collision, but a deeper slab is observed (Mitterbauer et al., 2011).

\section{Conclusions}


The Eastern Alps illustrate how the deformation pattern of a deforming collisional wedge is affected 1 ) by the presence of an advancing indenter corner and 2) by the presence of large, along-strike changes of crustal thickness.

The westward increase of thickness of the Alpine collisional wedge, due to the building of the antiformal stack of European basement nappes, terminates rather abruptly in the central part of the Eastern Alps, where it creates very significant gradients both in the surface elevation and the Moho topography. At the surface, this area corresponds to the Katschberg Fault, forming the eastern margin of the Tauern Window. At depth, it corresponds to the transition between an area, in the west, where the inferred European continental slab is imaged as attached to the European Moho and an area in the east, where no slab is imaged below the Moho. This lateral change in the mantle and crustal structure is the prime cause of the lateral gradients in thickness of the orogenic wedge that will eventually lead to lateral gradients in metamorphism and shortening. These, in turn, can explain the orogen-parallel flow component that affected the collisional wedge.

Exhumation in the western part of the Eastern Alps is mainly the consequence of nappe stacking, upright folding and erosion, leading to the formation of the Tauern Window. This area is bounded by extensional faults whose nucleation probably resulted from the geometry of the indenter corner in the west (Brenner Fault) and from crustal thickness and surface-elevation changes in the east (Katschberg Fault). Indeed, deformation due to indentation cannot be accommodated without orogen-parallel extension in front of the indenter corner, as shown by experiments and by the other example of an Alpine indenter corner, also associated to orogen-parallel extension at its front, namely along the Simplon Fault. 
In contrast to all other parts of the Alpine Chain, the site of major shortening in the European Basement did not shift towards the foreland during collision, thus allowing for the amplification of the large-scale antiform of European basement nappes. The latter process could not have been possible without efficient erosion of the growing antiformal structure. Over $20 \mathrm{~km}$ of crust, in the hinge area of this structure, were eroded throughout collision. The geometry of the reconstructed upright folds and their erosion level are consistent with the spatial patterns of metamorphic isograds and cooling ages in the exhumed metamorphic domes.

Provided our map-view retro-deformation is correct, collisional shortening between the Northern Calcareous Alps and the Dolomites Indenter decreases from west to east from 75 to $30 \mathrm{~km}$, corresponding to $41 \%$ and $15 \%$ of shortening, respectively. Approximately $55 \mathrm{~km}$ of the bulk $75 \mathrm{~km}$ of shortening were accommodated by upright folding in the Tauern Window. Orogen-parallel extension attained $85 \mathrm{~km}$ in the North-Calcareous Alps and some $45 \mathrm{~km}$ in the area immediately north of the indenter margin. These values correspond to an average of $17 \%$ of extension.

The Dolomites Indenter underwent a clockwise rotation within a system (the Adriatic Plate) that was rotating anticlockwise. Such a clockwise rotation resulted into larger amounts of shortening in the western part of the orogenic wedge, possibly due to an along-strike change of rheology originating from the Oligocene Barrovian metamorphism that affected and weakened the nappe stack of the Tauern Window.

In summary, the two questions formulated at the end of the introduction section may be answered as follows. 1. The limited area of exhumation of European basement in the Eastern Alps results from the long-term localization of shortening 
that was accommodated within a single structure, the Tauern Dome. 2. Exhumation occurred primarily by erosion of the aforementioned area of localized shortening and thickening.

XVII. Acknowledgements

Several research projects were made possible by funding of the Deutsche Forschungsgemeinschaft (Ro 2177-3; Ro 2177-4; Ro 2177-5; Ha 2403-10). We acknowledge numerous discussions with Mark Handy, Stefan Schmid and Silvia Favaro and an informal review by Hugo Ortner, although they do not share all interpretations of the present paper. F. Rossetti, S. Zanchetta, an anonymous reviewer, and the Editor C. Doglioni helped us clarifying several parts of the manuscript. Giancarlo Molli provided older, but still important literature. 
XVIII. References

Andeweg, B., and Cloetingh, S., 1998, Flexure and "unflexure" of the North Alpine German-Austrian Molasse Basin: constraints from forward tectonic modelling. In: Mascle, A., Puigdefabregas, C., Luterbacher, H. P., and Fernandez, M. (eds) Cenozoic Foreland Basins of Western Europe. Geological Society Special Publications, 134, 403-422.

Armstrong, R.L., 1982. Cordilleran metamorphic core complexes. Ann. Rev. Earth Planet. Sci. 10, 129-154.

Axen, G.J., Bartley, J.M., Selverstone, J., 1995. Structural expression of a rolling hinge in the footwall of the Brenner line normal fault, Eastern Alps. Tectonics 14, 1380-1392.

Batt, G.E., M.T. Brandon, 2001. Tectonic synthesis of the Olympic Mountains segment of the Cascadia wedge, using two-dimensional thermal and kinematic modelling of thermochronological ages. J. Geophys. Res. 106, 731-746.

Batt, G. E., Braun J., 1997. On the thermomechanical evolution of compressional orogens. Geophys. J. Int. 128, 364-382.

Behm, M., Brückl, E., Chwatal, W., Thybo, H., 2007. Application of stacking techniques to 3D wide-angle reflection and refraction seismic data of the Eastern Alps, Geophys. J. Int. 170, 275-298, doi10.1111/j.1365246X.2007.03393.x.

Behrmann, J.H., 1988. Crustal-scale extension in a convergent orogen: The SterzingSteinach mylonite zone in the Eastern Alps. Geodin. Acta 2, 63-73.

Behrmann, J.H., 1990. Zur Kinematik der Kontinentalkollision in den Ostalpen. Geotekt. Forsch. 76, 1-180. 
Beidinger, A., and Decker, K., 2014. Quantifying Early Miocene in-sequence and outof-sequence thrusting at the Alpine-Carpathian junction. Tectonics, 33, 222252, doi:10.1002/2012TC003250.

Bertrand, A., Rosenberg, C.L., and Garcia, S., 2015. Fault slip analysis and late exhumation of the Tauern Window, Eastern Alps. Tectonophysics 649, 1-17.

Bertrand, A., Rosenberg, C.L., Fügenschuh, B., Rabaute, A., and Herman, F., 2017. Exhumation mechanisms of the Tauern Window (Eastern Alps) inferred from Apatite and Zircon fission-track thermochronology. Tectonics, 36, doi:10.1002/2016TC00413.

Beyssac, O., Simoes, M., Avouac, J.P., Farley, K.A., Chen, Y-G., Chan, Y-C., Goffé, B., 2007. Late Cenozoic metamorphic evolution and exhumation of Taiwan, Tectonics 26, TC6001, doi10.1029/2006TC002064.

Bianchi, A.,1934. Studi petrografici sull'Alto Adige orientale e regioni limitrofe. Memorie Istituto Geologia Univ. Padova, 10, 1-240.

Bigi, G., Castellarin, A., Coli, M., Del Piaz, G., Sartori, R., Scandone, P., Parotto, M., 1990. Structural Model of Italy, scale 1: 500,000 sheet 1-3. Consiglio Nazionale delle Ricerche, Progetto Finalizzato Geodinamica, SELCA Firenze.

Bistacchi, A., Dal Piaz, G. V., Dal Piaz, G., Massironi, M., Monopoli, B., \& Schiavo, A., 2004. Carta geo-litologica e note illustrative del transetto Val di Vizze-Fortezza (Alpi orientali). Memorie Scienze Geologiche, 55(2003), 169-188.

Bistacchi, A., Massironi, M., Dal Piaz, G. V., Dal Piaz, G., Monopoli, B., Schiavo, A., \& Toffolon, G. (2007). 3D fold and fault reconstruction with an uncertainty model: An example from an Alpine tunnel case study. Computers \& Geosciences, 1-19. doi:10.1016/j.cageo.2007.04.002. 
Bokelmann, G., Qorbani, E., Bianchi, I., 2013. Seismic anisotropy and large-scale deformation of the Eastern Alps. Earth Planet. Sc. Lett. 383, 1-6.

Borsi, S., Del Moro, A., Sassi, F., 1973. Metamorphic evolution of the Austridic rocks to the south of the Tauern Window (Eastern Alps): radiometric and geopetrological data. - Mem. Soc. Geo. It., 12, 549-571.

Borsi, S., Del Moro, A., Sassi, F., Zanferrari, A., Zirpoli, G., 1978, New geopetrologic and radiometeric data on the alpine history of the Austridic continental margin South of the Tauern window (Eastern Alps). Memorie dell'Istituto della Regia Universitá di Padova 32, 1-20.

Bousquet, R., Oberhänsli, R., Goffe', B., Wiederkehr, M., Koller, F., Schmid, S.M., Schuster, R., Engi, M., Berger, A., Martinotti, G., 2008. Metamorphism of metasediments at the scale of an orogen: a key to the Tertiary geodynamic evolution of the Alps. In: Siegesmund, S., Fügenschuh, B. and Froitzheim, N. (Eds) Tectonic Aspects of the Alpine-Dinaride-Carpathian System. Geol. Soc. Spec. Publ. 298, 393-411.

Bousquet, R., Schmid, S.M., Zeilinger, G., Oberhänsli, R., Rosenberg, C.L., Molli, G., Robert, C., Wiederkehr, M., Rossi, P., 2012. Tectonic framework of the Alps. CCGM/CGMW.

Brandner R, Reiter F, Töchterle, A., 2008, Überblick zu den Ergebnissen der geologischen Vorerkundung für den Brenner Basistunnel. Geo Alp 5:165174.

Brichau, S., Ring, U., Ketcham, R.A., Carter, A., Stockli, D., Brunel, M., 2006. Constraining the long-term evolution of the slip rate for a major extensional fault system in the central Aegean, Greece, using thermochronology. Earth Planet. Sc. Lett. 241, 293-306, doi10.1016/j.epsl.2005.09.065. 
Brückl, E., Bleibinhaus, F., Gosar, A., Grad, M., Guterch, A., Hrubcová, P., Yliniemi, J.,2007. Crustal structure due to collisional and escape tectonics in the Eastern Alps region based on profiles Alp01 and Alp02 from the ALP 2002 seismic experiment, J. Geophys. Res. 112, B06308, doi10.1029/2006JB004687.

Brückl, E., Behm, M., Decker, K., Grad, M., Guterch, A., Keller, G.R., Thybo, H., 2010. Crustal structure and active tectonics in the Eastern Alps. Tectonics 29, TC2011, doi10.1029/2009TC002491.

Brügel, A., Dunkl, I., Frisch, W., Kuhlemann, J., Balogh, K., 2003. Geochemistry and geochronology of gneiss pebbles from foreland molasse conglomerates: geodynamic and paleogeographic implications for the Oligo-Miocene evolution of the Eastern Alps. J. Geol. 111, 543-563.

Buck, W.R., 1988. Flexural rotation of normal faults. Tectonics 7, 959-973.

Burg, J.-P., Kaus, B., Podlachikov, Y., 2004. Dome structures in collision orogens: Mechanical investigation of the gravity/compression interplay. Geol. Soc. Am. S. 380, 47-66.

Cao, S., Neubauer, F., Bernroider, M., Liu, J., Genser, J., 2013. Structures, microfabrics and textures of the Cordilleran-type Rechnitz metamorphic core complex, Eastern Alps. Tectonophysics 608, 1201-1225.

Caporali, A., Neubauer, F., Ostini, L., Stangl, G. Zuliani, D., 2013. Modeling surface GPS velocities in the southern and Eastern Alps by finite dislocations at crustal depths. Tectonophysics 590, 136-150.

Castellarin, A., Nicolich, R., Fantoni, R., Cantelli, L., Sella, M., \& Selli, L., 2006. Structure of the litho- sphere beneath the Eastern Alps (southern sector of the TRANSALP transect). Tectonophysics, 414 , 259-282, doi:10.1016/j.tecto.2005.10.013. 
Chamberlain, K.R., Bowring, S.A., 2000. Apatite-feldspar U-Pb thermochronometer: a reliable, mid-range $\left(\sim 450{ }^{\circ} \mathrm{C}\right)$, diffusion-controlled system. Chem. Geol. 172, 173-200.

Christensen, J.N., Selverstone, J., Rosenfeld, J.L. \& DePaolo, D.J., 1994. Correlation of $\mathrm{Rb}-\mathrm{Sr}$ geochronology of garnet growth histories from different structural levels within the Tauern Window, Eastern Alps. Contributions to Mineralogy and Petrology, 118, 1-12.

Cliff, R.A., Droop, G.T.R., Rex, D.C., 1985. Alpine metamorphism in the south-east Tauern Window, Austria: 2. Rates of heating, cooling and uplift. J. metamorph. Geol. 3, 403-415.

Cliff, R.A., Oberli, F., Meier, M., Droop, G.T R., Kelly, M., 2015. Syn - metamorphic folding in the Tauern Window, Austria dated by Th-Pb ages from individual allanite porphyroblasts. J. metamorph. Geol. 33, 427-435.

Cole, J., Hacker, B., Ratscbacher, L., Dolan, J., Seward, G., Frost, E., Frank, W., 2007. Localized ductile shear below the seismogenic zone: structural analysis ofan exhumedstrike-slipfault, Austrian Alps. J. Geophys. Res. 112, doi10.1029/2007JB004975.

Cooper, F.J., Hodges, K.V., Parrish, R.R., Roberts, N.M.W., Horstwood, M.S.A., 2015. Synchronous N - S and E - W extension at the Tibet - to - Himalaya transition in NW Bhutan. Tectonics 34, 1375-1395. doi10.1002/2014TC003712.

Cornelius H. P., 1940. Zur Auffassung der Ostalpen im Sinne der Deckenlehre. Z. Deutsch. Geol. Ges. 92, 271-312.

Coyle, D.A., 1994. The application of apatite fission track analysis to problem in tectonics. PhD Thesis, La Trobe University, Bundoora, Victoria.

Cuffaro, M., Riguzzi, F., Scrocca, D., Antonioli, F., Carminati, E., Livani, M., Doglioni, C., 
2010, On the geodynamics of the northern Adriatic plate. Rend. Fis. Acc. Lincei, 21, 253-279. DOI 10.1007/s12210-010-0098-9.

D’Agostino, N., Cheloni, D., Mantenuto, S., Selvaggi, G., Michelini A., and Zuliani, D., 2005, Strain accumulation in the southern Alps (NE Italy) and deformation at the northeastern boundary of Adria observed by GPS measurements. Geophysical Research Letters, 32, L19306, doi:10.1029/2005GL024266.

Dal Piaz G.B., 1934, Studi geologici sull'Alto Adige orientale e regioni limitrofe. Mem. Ist. Geol. R. Univ. Padova, 10, 1-242.

Dal Piaz, G.V., Del Moro, A., Martin, S., and Venturelli, G., 1988, Post-Collisional Magmatism in the Ortler-Cevedale Massif (Northern Italy).

Dal Piaz, G.V., Bistacchi, A., and Massironi, M., 2003, Geological outline of the Alps. Episodes, 6, 175-180.

Dando, B.D.E., G.W. Stuart, G. A. Houseman, E. Hegedüs, E. Brückl and S. Radovanovi', 2011, Teleseismic tomography of the mantle in the Carpathian-Pannonian region of central Europe. Geophys. J. Int., 186, 11-31.

Davy, P.H., Cobbold, P.R., 1988. Indentation tectonics in nature and experiments 1. Experiments scaled for gravity, Bull. Geol. Inst. Uppsala 14, 129-141.

De Vecchi, G., and Baggio, P.,1982. The Pennine zone of the Vizze region in the western Tauern window (Italian eastern Alps). Boll. Societa` Geologica Italiana, 101, 89-116.

Di Fiore, G., 2012. Evoluzione Morfotettonica delle aree alpine „Sempione“ e "Brennero" attraverso studi termocronologici di bassa temperatura. PhD Thesis, University of Bologna.

Dingeldey, C., Dallmeyer, R.D., Koller, F., Massonne, H.J., 1997. P-T-t history of the Lower Austroalpine Nappe Complex in the "Tarntaler Berge" NW of the Tauern 
Window: implications for the geotectonic evolution of the central Eastern Alps. Contrib. Mineral. Petr. 129, 1-19.

Doglioni C., 1987, Tectonics of the Dolomites (Southern Alps, Northern Italy). Journal of Structural Geology, 9, 2, 181-193.

Doglioni, C. and Bosellini, A., 1987, Eoalpine and mesoalpine tectonics in the Southern Alps. Geol. Rund., 76, 735-754.

Doglioni, C., 1992. Relationships between Mesozoic extensional tectonics, stratigraphy and Alpine inversion in the Southern Alps. Eclog. Geol. Helv., 85, $105-126$

Doglioni, C., E. Carminati, 2002. The effects of four subductions in NE Italy, Mem. Sci. Geol. 54, 1-4.

Doglioni, C., Carminati, E., Cuffaro, M., and Scrocca, D., 2007, Subduction kinematics and dynamic constraints. Earth Science Reviews, 83, 125-175.

Droop, G.T.R., 1985. Alpine metamorphism in the south-east Tauern Window, Austria: 1. P-T variations in space and time. J. metamorph. Geol. 3, 371-402.

Dunkl, I., Demeny, A., 1997. Exhumation of the Rechnitz Window at the border of the Eastern Alps and Pannonian Basin during Neogene extension. Tectonophysics $272,197-211$.

Dunkl, I., Frisch, W., Grundmann, G., 2003. Zircon fission track thermochronology of the south-eastern part of the TW and the adjacent Austroalpine margin, Eastern Alps. Eclogae geol. Helv. 96, 209-217.

Elias, J., 1998. The Thermal History of the Ötztal-Stubai Complex (Tyrol, Austria/Italy) in the light of the lateral extrusion model. PhD, University of Tübingen. 
England, P., and Thompson, A. B., 1984. Pressure-Temperature-time paths of regional metamorphism I. Heat transfer during the evolution of regions of thickened continental crust. JournaJ of Petrology, 25, 894-928.

Exner, C., 1954. Die Südost-Ecke des Tauernfensters bei Spittal an der Drau. Jb. Geol. B.-A. $97,17-37$.

Exner, C., 1956, Geologische Karte der Umgebung von Gastein. Geologische Bundesanstalt, Wien.

Exner, C. 1962. Sonnblicklamelle und Moelltallinie. Jb. Geol. B.-A., 105, 273-286.

Exner, C., 1964, Geologische Karte der Sonnblickgruppe. Zusammendruck aus den Blättern der Österreichischen Karte $1: 50.000,154,155,180,181$. Geologische Bundesanstalt, Wien.

Exner, C., 1980. Geologie der Hohen Tauern bei Gmünd in Kärnten. Jb. Geol. B.-A. $123,343-410$.

Exner, C. 1983. Karte der Hafnergruppe. Mitt. D. Ges. Geol. U. Bergbaustudenten in Oesterreich, 29.

Exner, C. 1991. Bundschuhgneis und Granatglimmerschiefer bei Ramingstein (Lungau, Salzburg). Jb. Geol. B.-A., 134(1), 15-25.

Exner, C. 1996. Leitgesteine und Tektonik in Phylliten bei Wagrain und Radstadt (Land Slazburg). Jb. Geol. B.-A., 139(2), 155-190.

Favaro, S., Schuster, R., Handy, M.R., Scharf, A., Pestal, G., 2015. Transition from orogen-perpendicular to orogen-parallel exhumation and cooling during crustal indentation - Key constraints from ${ }^{147} \mathrm{Sm} /{ }^{144} \mathrm{Nd}$ and ${ }^{87} \mathrm{Rb} /{ }^{87} \mathrm{Sr}$ geochronology (Tauern Window, Alps). Tectonophysics 665, 1-16, doi10.1016/j.tecto.2015.08.037. 
Favaro, S., Handy M.R., Scharf A., Schuster R., 2017, Changing patterns of exhumation and denudation in front of an advancing crustal indenter, Tauern Window (Eastern Alps). Tectonics, 36, 1053-1071, doi:10.1002/2016TC004448.

Flisch, M., 1986, Die Hebungsgeschichte der oberostalpinen Silvretta-Decke seit der mittleren Kreide. Bulletin der Vereinigung schweizerische PetroleumGeologen Ingenieure, 53, 23-49.

Fodor, L. I., et al., 2008, Miocene emplacement and rapid cooling of the Pohorje pluton at the Alpine-Pannonian-Dinaridic junction, Slovenia, Swiss J. Geosci., 101, 255 - 271, doi:10.1007/s00015-008-1286-9.

Foeken, J.P.T., Persano, C., Stuart, F.M., ter Voorde, M., 2007. Role of topography in isotherm perturbation: Apatite (U-Th)/He and fission track results from the Malta tunnel, Tauern Window, Austria. Tectonics 26. TC3006, doi10.1029/2006TC002049.

Foster, D.A., Schafer, C., Fanning, M.C., Hyndmann, D.W., 2001. Relationships between crustal partial melting, plutonism, orogeny, and exhumation: IdahoBitterroot batholith. Tectonophysics, 342, 313-350.

Foster, D.A., Grice Jr., W.C., Kalakay, T.J., 2010. Extension of the Anaconda metamorphic core complex: ${ }^{40} \mathrm{Ar} /{ }^{39} \mathrm{Ar}$ thermochronology and implications for Eocene tectonics of the northern Rocky Mountains and the Boulder batholith. Lithosphere 2, 232-246; doi10.1130/L94.1

Fox, M., Herman, F., Willett, S.D., and Schmid, S.M., 2016, The exhumation history of the European Alps inferred from linear inversion of thermochronometric data. American Journal of Science, 316, 505-541, DOI 10.2475/06.2016.01.

Frank, W. and Pestal, G., 2008. Geologische Karte - Umgebung vom Wagrain. Jb. Geol. B.-A. H.1. 
Frey, M., Desmons, J., and Neubauer, F., 1999, The new metamorphic map of the Alps. Schweizerische Mineralogische Petrographische Mitteilungen, 79, 1-4.

Frisch, W., 1974, Die stratigraphisch tektonische Gliederung der Schieferhülle und die Entwicklung des penninischen Raumes im westlichen Tauernfenster (Gebiet Brenner-Gerlosspass): Mitteilungen der Österreichischen Geologischen Gesellschaft, Vienna, Austria, 66/67, 9 - 20.

Frisch, W., Kuhlemann, A., Dunkl, I., Brügel, A., 1998. Palinspastic reconstruction and topographic evolution of the Eastern Alps during late Tertiary tectonic extrusion. Tectonophysics, 297, 1-15.

Frisch, W., Dunkl, I., Kuhlemann, J., 2000. Post-collisional orogen-parallel large-scale extension in the Eastern Alps. Tectonophysics, 327, 239-265.

Frisch W., Kuhlemann J., Dunkl I., Székely B., 2001. The Dachstein paleosurface and the Augenstein formation in the Northern Calcareous Alps-a mosaic stone in the geomorphological evolution of the Eastern Alps. Int J Earth Sci 90:500518.

Fügenschuh, B., Seward, D., Mantckelow, N.S., 1997. Exhumation in a convergent orogen: the western Tauern Window. Terra Nova, 9, 213-217.

Fügenschuh, B., Mancktelow, N.S., Schmid, S.M., 2012. Comment on Rosenberg and Garcia, 2011: Estimating displacement along the Brenner Fault and orogenparallel extension in the Eastern Alps. Int. J. Earth Sci. 101, 1451-1455.

Gallagher, K., Brown, R., Johnson, C., 1998. Fission track analysis and its applications to geological problems. Annu. Rev. Earth Pl. Sc. 26, 519-572.

Gebrande, H., Lüschen, E., Bopp, M., Bleibinhaus, F., Lammerer, B., Oncken, O., ..., Grassl, H., 2002. First deep seismic reflection images of the Eastern Alps reveal 
giant crustal wedges and transcurrent ramps. Geophys. Res. Lett. 29, 92-1-924.

Genser, J., Neubauer F., 1989. Low angle normal faults at the eastern margin of the Tauern Window (Eastern Alps). Mitt. österr. geol. Ges. 81, 233-243.

Genser, J., van Wees, J.D., Cloetingh, S., and Neubauer, F., 1996, Eastern Alpine tectono-metamorphic evolution: Constraints from two-dimensional P-T-t modeling. Tectonics, 15, 584-604.

Gemignani, L., X. Sun, J. Braun, T. D. van Gerve, and J. R. Wijbrans, 2017, A new detrital mica 40Ar/39Ar dating approach for provenance and exhumation of the Eastern Alps, Tectonics, 36, 1521-1537, doi:10.1002/2017TC004483.

Glodny, J., Ring, U., Kühn, A., Gleissner, P., Franz, G., 2005. Crystallization and very rapid exhumation of the youngest Alpine eclogites (Tauern Window, Eastern Alps) from Rb/Sr mineral assemblage analysis. Contrib. Mineral. Petr. 149, 699-712.

Glodny, J., Ring, U., Kühn, A., 2008. Coeval high-pressure metamorphism, thrusting, strike slip, and extensional shearing in the Tauern Window, Eastern Alps. Tectonics 27:TC4004. doi10.1029/2007TC002193.

Goffé, B., Bousquet, R., Henry, P., and Le Pichon, X., 2003, Effect of the chemical composition of the crust on the metamorphic evolution of orogenic wedges. Journal of metamorphic Geology, 21, 123-141.

Grujic, D., 2006, Channel flow and continental collision tectonics : an overview. In : Law, R. D., Searle, M. P. and Godin, L. (Eds) Channel Flow, Ductile Extrusion and Exhumation in Continental Collision Zones. Geological Society, London, Special Publications, 268, 25-37. 
Grundmann, G. and Morteani, G., 1985. The young uplift and thermal history of the central Eastern Alps (Austria/Italy), evidence from apatite fission track ages. Jb. Geol. B.-A. 128, 197-216.

Hawkesworth, C.J., Waters, D.J., and Bickle, M.J., 1975, Plate tectonics of the Eastern Alps. Earth and Planetary Science Letters, 24, 405-413.

Handy, M. and Oberhänsli, R. 2004. Age map of the metamorphic structure of the Alps-Tectonic interpretation and outstanding problems. In: Oberhänsli, R. (Ed.) Explanatory note to the map 'Metamorphic structure of the Alps' Mitteilungen Österreichische Mineralogischen Gesellschaft, Wien, 201-226.

Handy, M., Ustaszewski, and K., Kissling, E., 2014. Reconstructing the AlpsCarpathians-Dinarides as a key to understanding switches in subduction polarity, slab gaps and surface motion. Int. J. Earth Sci. doi10.1007/s00531014-1060-3.

Harangi, S., and Lenkey, L., 2007, Genesis of the Neogene to Quaternary volcanism in the Carpathian-Pannonian region: Role of subduction, extension, and mantle plume. Geological Society of America, Special Paper 418, 67-92.

Heberer, B., Reverman, R.L., Fellin, M.G., Neubauer, F., Dunkl, I., Zattin, M., Seward, D., Genser, J., and Brack, P., 2017, Postcollisional cooling history of the Eastern and Southern Alps and its linkage to Adria indentation. Int. J. Eart Sci. (Geol. Rundsch.), 106, 1557-1580.

Hejl, E., 1997. 'Cold spots' during the Cenozoic evolution of the Eastern Alps: Thermochronological interpretation of apatite fission-track data, Tectonophysics 272, 159-173, doi10.1016/S0040-1951(96)00256-9.

Hejl, E., 1998. Über die känozoische Abkühlung und Denudation der Zentralalpen östlich der Hohen Tauern: Eine Apatit - Spaltspurenanalyse, Mitt. österr. geol. 
Ges. 89, 179-200.

Hoinkes G., Koller F., Rantitsch G., Dachs E., Hoånck V., Neubauer F., Schuster R., 1999. Alpine metamorphism of the Eastern Alps. Schweiz. Mineral. Petrogr. Mitt. 79, 155-181.

Höck, V., 1980. Distribution maps of minerals oft he Alpine metamorphism in the Penninic Tauern window, Austria. Mitt. österr. geol. Ges. 71/72, 119-127.

Hoernes, S., Friedrichsen, H., 1974. Oxygen isotope studies on metamorphic rocks of the western Hohe Tauern area (Austria). Schweiz. Min. Petr. Mitt. 54, 769-788.

Horvath, F., 1995, Phases of compression during the evolution of the Pannonian Basin and its bearing on hydrocarbon exploration. Marine and Petroleum Geology 1995 12, 837-844.

Houseman, G., England, P., 1993. Crustal thickening versus lateral expulsion in the Indian-Asian continental collision, J. geophys. Res. 98, 12,233-12,249.

Hurford, A.J., P.F. Green, P.F, 1983. The zeta age calibration of fission track dating. Chem. Geol. 41, 285-317.

Inger, S. and Cliff, R.A., 1994, Timing of metamorphism in the Tauern Window, Eastern Alps: Rb-Sr ages and fabric formation. J. metamorph. Geol. 12, 695707.

John, B.E., Foster, D.A., 1993. Structural and thermal constraints on the initiation angle of detachment faulting in the southern Basin and Range: The Chemehuevi Mountains case study: Geol. Soc. Am. Bull. 105, 1091-1108, doi10.1130/0016-7606.

John, B. E., Howard, K.A., 1995. Rapid extension recorded by cooling-age patterns and brittle deformation, Naxos, Greece. J. geophys. Res. 100, 9969-9979. 
Johnson M.R.W., 2002. Shortening budgets and the role of continental subduction during the India-Asia collision. Earth. Sci. Rev. 59, 101-123.

Keller, L.M., Fügenschuh, B., Hess, M., Schneider, B., Schmid, S.M., 2006. Simplon fault zone in the western and central Alps: Mechanism of Neogene faulting and folding revisited. Geology 34, 317-320.

Klepeis, K.A., Crawford, M.L., 1999. High-temperature arc-parallel normal faulting and transtension at the roots of an obliquely convergent orogen. Geology 27, $7-10$.

Koulakov, I., Kaban, M.K., Tesauro, M., Cloetingh, S., 2009. P- and S-velocity anomalies in the upper mantle beneath Europe from tomographic inversion of ISC data. Geophys. J. Int. 179, 345-366. doi.org/10.1111/j.1365246X.2009.04279.x.

Kuhlemann, J., Frisch, W., Dunkl, I., Székely, B., 2001. Quantifying tectonic versus erosive denudation by the sediment budget: the Miocene core complexes of the Alps. Tectonophysics 330, 1-23.

Kuhlemann, J., Frisch, W., Székely, B., Dunkl, I., Kázmér, M., 2002. Post-collisional sediment budget history of the Alps: tectonic versus climatic control. Int. J. Earth Sci. 91, 818-837. doi10.1007/s00531-002-0266-y.

Kurz, W., Neubauer, F., 1996. Deformation partitioning during updoming of the Sonnblick area in the Tauern Window (Eastern Alps, Austria), J. Struct. Geol., $18,1327-1343$.

Kurz, W., Neubauer, F., and Genser, J., 1996, Kinematics of Penninic nappes (Glockner Nappe and basement-cover nappes) in the Tauern Window (Eastern Alps, Austria) during subduction and Penninic-Austroalpine collision. Eclogae geol. Helv. 89/1:573-605. 
Kurz, W., Neubauer, F., Genser, J., \& Dachs, E. (1998). Alpine geodynamic evolution of passive and active continental margin sequences in the Tauern Window (Eastern Alps, Austria, Italy): A review. Geol. Rundschau, 87, 225-242.

Kurz, W., Handler, R., Bertoldi, C., 2008. Tracing the exhumation of the Eclogite Zone (Tauern Window, Eastern Alps) by ${ }^{40} \mathrm{Ar} /{ }^{39} \mathrm{Ar}$ dating of white mica in eclogites. Swiss J. Geosci. 101, 191-206, doi10.1007/s00015-008-1281-1.

Kurz, W., Wölfler, A., Rabitsch, R., Genser, J., 2011. Polyphase movement on the Lavanttal Fault Zone (Eastern Alps): reconciling the evidence from different geochronological Indicators. Swiss J. Geosci., 104, 323-343. doi10.1007/s00015-011-0068-y.

Lammerer, B., Weger, M., 1998. Footwall uplift in an orogenic wedge: the Tauern Window in the Eastern Alps of Europe. Tectonophysics 285, 213-230.

Lammerer, B. Gebrande, H., Lüschen, E. Vesela, P., 2008. A crustal-scale cross section through the Tauern Window (Eastern Alps) from geophysical and geological data. In: Tectonic Aspects of the Alpsine-Carpathian-Dinaride System, edited by Siegesmund, S., Fügenschuh, B. and Froitzheim, N., Geol. Soc. Spec. Publ., $219-229$.

Lammerer, B., Selverstone, J., Franz, G., 2011. Field trip to the Tauern Window region along the TRANSALP seismic profile, Eastern Alps, Austria. The Geological Society of America, Field Guide 22, pp. 20.

Laubscher, H.-P., 1983. Detachment, shear and compression in the Central Alps. Geol. Soc. Am. Mem. 158, 191-211.

Laubscher, H.-P., 1985. Large-scale, thin-skinned thrusting in the southern Alps: Kinematic models. Geol. Soc. Am. Bull. 96, 710-718.

Lickorisch, W.H., Ford, M., Bürgisser, J., Cobbold, P.R., 2004. Arcuate thrust systems 
in sandbox experiments: A comparison to the external arcs of the Western Alps. Geol. Soc. Am. Bull. 114, 1089-1107.

Linzer, H.G., Decker, K., Peresson, H., Dell'Mour, R., Frisch, W., 2002. Balancing orogenic float of the Eastern Alps: Tectonophysics 354, 211-237.

Lippitsch, R., Kissling, E., Ansorge, J., 2003. Upper mantle structure beneath the Alpine orogen from high-resolution teleseismic tomography, J. geophys. Res., 108, 2376, doi10.1029/2002JB002016.

Lister, G.S., Davis, G.A., 1989. The origin of metamorphic core complexes and detachment faults formed during Tertiary continental extension in the northern Colorado River region, U.S.A. J. struct. Geol. 11, 65-94.

Lu, C.Y., Malavieille, J., 1994. Oblique convergence, indentation and rotation tectonics in theTaiwan Mountain Belt: Insights from experimental modelling. Earth Planet. Sc. Lett. 121, 477-494.

Luciani, V., Silvestrini, A., 1996. Planktonic foraminiferal biostratigraphy and paleoclimatology of the Oligocene/Miocene transition from the Monte Brione Formation (Northern Italy, Lake Garda). Memorie di Scienze Geologiche 48, 155-169.

Lünsdorf, N.K., Dunkl, I., Schmidt, B.C., Rantitsch, G., von Eynatten, H., 2012. The thermal history of the Steinach Nappe (Eastern Alps) during extension along the Brenner Normal Fault System indicated by organic maturation and zircon (U-Th)/He thermochronology. Aus. J. Earth Sci. 105, 17-25.

Luth, S.W., Willingshofer, E., 2008. Mapping of the Post-Collisional Cooling History of the Eastern Alps. Swiss J. Geosci. 101, 201-223. 
Luth, S., Willingshofer, E., Sokoutis, D., and Cloetingh, S., 2013. Does subduction polarity changes below the Alps? Inferences from analogue modelling. Tectonophysics, 582, 140-161.

Luth, S., Willingshofer, E., ter Brogh, M., Sokoutis, D., van Otterloo, J., Versteeg, A., 2013. Kinematic analysis and analogue modelling of the Passeier- and Jaufen faults: implications for crustal indentation in the Eastern Alps. Int. J. Earth Sci. 102, 1071-1090. doi10.1007/s00531-012-0846-4.

Mancktelow N.S., 1985. The Simplon Line: A major displacement zone in the western Lepontine Alps, Eclogae geol. Helv. 78, 73-96.

Mancktelow, N.S., Pavlis, T.L., 1994. Fold-fault relationships in low-angle detachment system. Tectonics 13, 668-685.

Mancktelow, N.S., Stöckli, D.F., Grollimund, B., Müller, W., Fügenschuh, B., Viola, G., Seward, D., Villa, I.M., 2001. The DAV and Periadriatic fault systems in the Eastern Alps south of the Tauern Window. Int. J. Earth Sci. 90, 593-622, doi10.1007/s005310000190.

Martin, S., Prosser, G., Morten, L., 1993. Tectono-magmatic evolution of sheeted plutonic bodies along the north Giudicarie line (northern Italy). Int. J. Earth Sci. $82,51-66.82,51-66$

Martin, S., Bigazzi, G., Zattin, M., Viola, G., Balestrieri, M.L., 1998. Neogene kinematics of the Giudicarie Fault (Central Eastern Alps, Italy): new apatite fission track data. Terra Nova 10, 217-221.

Matenco, L., and D. Radivojević, 2012, On the formation and evolution of the Pannonian Basin: Constraints derived from the structure of the junction area between the Carpathians and Dinarides. Tectonics, 31, TC6007, doi:10.1029/2012TC003206. 
Métois, M., N. D’Agostino, A. Avallone, N. Chamot-Rooke, A. Rabaute, L. Duni, N. Kuka, R. Koci, and I. Georgiev, 2015. Insights on continental collisional processes from GPS data: Dynamics of the peri-Adriatic belts, J. Geophys. Res. Solid Earth, 120, 8701-8719, doi:10.1002/2015JB012023.

Metz, K., 1973. Beiträge zur tektonischen Baugeschichte und Position des Fohnsdorf - Knittelfelder Tertiärbeckens, Mitt Abt. Geol. Palaeont. Landesmuseum Joanneum 33, 4-33.

Metz, K., 1976. Bruchsysteme und Westbewegungen in den östlichen Zentralalpen, Mitt. österr. geol. Ges. 69, 27-47.

Mitterbauer, U., Behm, M., Brückl, E., Lippitsch, R., Guterch, A., Keller, G.R., Koslovskaya, E, Rumpfhuber, E.-M., Sumanovac, F., 2011. Shape and origin of the East-Alpine slab constrained by the ALPASS teleseismic model. Tectonophysics 510, 195-206.

Molinari, I., Raileanu, V., Morelli, A., 2012. A crustal model for the Eastern Alps region and a new Moho map in southeastern Europe. Pure Appl. Geophys. 169, 1575-1588.

Molnar, P., Tapponnier, P., 1975. Cenozoic Tectonics of Asia: Effects of a Continental Collision. Science 189, 419-426.

Morteani, G., 1974, Petrology of the Tauern Window, Austrian Alps. Fortschr. Miner. $52,195-220$.

Morteani, G., \& Raase, P., 1974, Metamorphic plagioclase crystallization and zones of equal anorthite content in epidote-bearing, amphibole-free rocks of the western Tauernfenster (Eastern Alps). Lithos, 7, 101-111.

Most, P., 2003. Late Alpine cooling histories of tectonic blocks along the central part of the Transalp-Traverse (Inntal - Gadertal): constraints from geochronology. 
PhD thesis, Universität Tübingen, Tübingen, 97 pp.

Mouthereau, F., Fillon, C., and Ma, K.-F., 2009, Distribution of strain rates in the Taiwan orogenic wedge. Earth and Planetary Science Letters 284:361-385.

Müller W., Prosser G., Mancktelow N.S., Villa I.M., Kelley S., Viola G., Oberli F., Nemes

F., Neubauer F., 2001. Geochronological constraints on the evolution of the Periadreatic Fault System (Alps). Int. J. Earth Sci. 90, 623-653.

Muñoz, J.A., 1992. Evolution of a continental collision belt: ECORSPyrenees crustal balanced cross section, in Thrust Tectonics, edited by K. R. McClay, pp. 235246, Chapman and Hall, London.

Nagel, T.J., Herwartz, D., Rexroth, S., Münker, C., Froitzheim, N., Kurz, W., 2013. Lu-Hf dating, petrography, and tectonic implications of the youngest Alpine eclogites (Tauern Window, Austria). Lithos 170-171, 179-190.

Neubauer, F. Genser, J., 1990. Architektur und Kinematik der östlichen Zentralalpen--eine Übersicht. Mitt. Naturwiss. Ver. Steiermark 120: 203-219. Neubauer, F., Genser, J., Kurz, W., Wang, X., 1999. Exhumation of the Tauern Window, Eastern Alps. Phys. Chem. Earth 24, 675-680.

Nicolich, R., and G. Dal Piaz (1991), Isobate della Moho in Italia, in Structural Model of Italy, 6 fogli 1:500,000, Progetto Finalizzato “Geodinamica” CNR, Rome.

Nussbaum, C., 2000. Neogene tectonics and thermal maturity of sediments of the easternmost Southern Alps (Friuli area, Italy), PhD Thesis, Univ. of Neuchâtel, Switzerland.

Oberhänsli, R., Bousquet, R., Engi, M., Goffé, B., Gosso, G., Handy, M., et al. (2004). Metamorphic structure of the Alps. Paris, Commission for the Geological Map of the World.

Oehlke, M., Weger, M., and Lammerer, B., 1993, The "Hochfeiler Duplex" - 
Imbrication Tectonics in the SW Tauern Window. Abhandlungen der Geologische Bundesanstalt, Wien, 107-124.

Ortner, H., Reiter, F., Brandner, F., 2006. Kinematics of the Inntal shear zone-subTauern ramp fault system and the interpretation of the TRANSALP seismic section, Eastern Alps, Austria. Tectonophysics 414, 241-258.

Ortner, H., S. Aichholzer, M. Zerlauth, R. Pilser, and B. Fügenschuh (2015), Geometry, amount, and sequence of thrusting in the Subalpine Molasse of western Austria and southern Germany, European Alps, Tectonics, 34, 1-30, doi:10.1002/2014TC003550.

Pécskay, Z., Lexa, J., Szakács, A., Seghedi, I., Balogh, K., Konečný, V., Zelenka, T., Kovacs, M., Póka, T., Fülöp, A., Márton, E., Panaiotu, C., Cvetković, A., V., 2006, Geochronology of Neogene magmatism in the Carpathian Arc and intraCarpathian area. Geologica Carpathica, 57, 6, 511-530

Piromallo, C., Morelli, C., 2003. P wave tomography of the mantle under the AlpineMediterranean area. J. Geophys. Res. 108, 2065.

Polino, R., Dal Piaz, G. V., and Gosso, G., 1990, Tectonic erosion at the Adria margin and accretionary processes fort he Cretaceous Alpine orogen. Mémoires de la Société géologique de France, 156, 345-367.

Polinski, R.K., Eisbacher, G.H., 1992. Deformation partitioning during polyphase oblique convergence in the Karawanken Mountains, southeastern Alps. J. struct. Geol. 14, 1203-1213.

Pollington, A.D., Baxter, E.F., 2010. High resolution Sm-Nd garnet geochronology reveals the uneven pace of tectono-metamorphic processes. Earth Planet. Sci. Lett. 293, 63-71.

Pomella, H., Klötzli, U., Scholger, R., Stipp, M., Fügenschuh, B. 2011. The northern 
Giudicarie and the Meran-Mauls fault (Alps, northern Italy) in the light of new paleomagnetic and geochronological data from boudinaged Eo-/Oligocene tonalities, Int. J. Earth Sci. 100, 1827-1850., doi10.1007/s00531-010-0612-4.

Pomella, H., Stipp, M., Fügenschuh, B., 2012. Thermochronological record of thrusting and strike-slip faulting along the Giudicarie fault system (Alps, Northern Italy). Tectonophysics 579, 118-130.

Prey, S., 1977, Gelegenheitsbeobachtungen im Brennermesozoikum in der Umgebung von Trins (Gschnitztal, Tirol). Verhandlungen der geologischen Bundesanstalt, Wien.

Prey, S. 1980. Die Geologie Österreichs in ihrem heutigen geodynamischen Entwicklungstand sowie die geologischen Bauteile und ihre Zusammenhänge. In: Oberhauser, R. (editor), Der geologische Aufbau Österreichs, 79-117, Springer Verlag, Wien-New York.

Qorbani, E., Bokelmann, G., Bianchi, I., 2014. Slab detachment under the Eastern Alps seen by seismic anisotropy. Earth Planet. Sc. Lett. 409, 96-108.

Ratschbacher, L., Frisch, W., Neubauer, F., Schmid, S.M., Neugebauer, J., 1989. Extension in compressional orogenic belts: The Eastern Alps, Geology 17, 404407.

Ratschbacher, L., Merle, O., Davy, P., Cobbold, P., 1991a. Lateral extrusion in the Eastern Alps, Part 1: Boundary conditions and experiments scaled for gravity. Tectonics, 10, 245-256.

Ratschbacher, L., W. Frisch, and H-G. Linzer, 1991b. Lateral extrusion in the Eastern Alps: Part II. Structural analysis. Tectonics, 10, 257-271.

Ratschbacher, L., Dingeldey, C., Miller, C., Hacker, B.R., McWilliams, M.O., 2004. Formation, subduction, and exhumation of Penninic oceanic crust in the 
Eastern Alps: time constraints from ${ }^{40} \mathrm{Ar} /{ }^{39} \mathrm{Ar}$ geochronology. Tectonophysics $394,155-170$.

Reddy, S. M., Cliff, R. A., and East, R., 1993, Thermal history of the Sonnblick Dome, Tauern Window, Austria: Implications for Heterogeneous Uplift within the Pennine basement. Geol. Rundsch., 82:667-675.

Reiter, K., Kukowski, N., Ratschbacher, L., 2011. The interaction of two indenters in analogue experiments and implications for curved fold-and-thrust belts. Earth Planet. Sc. Lett. 302, 132-146.

Robl, J., Stüwe, K., 2005. Continental collision with finite indenter strength: 2. European Eastern Alps, Tectonics 24, TC4014, doi10.1029/2004TC001741.

Robinson, A.C., Yin, A., and Lovera, O.M., 2010. The role of footwall deformation and denudation in controlling cooling age patterns of detachment systems: An application to the Kongur Shan extensional system in the Eastern Pamir, China. Tectonophysics, 496, 28-43.

Rockenschaub, M. and Nowotny, A., 2009. Geological map sheet 149 Brenner 1:50.000. Wien: Geologische Bundesanstalt.

Rockenschaub, M., Nowotny, A., Brandner, R., Fenti, V., Frisch, W., Friz, C., Frizzo, P., Kolenprat, B., Magiera, J., Prager, C., Reiser, M., Scheiber, T., Bistacchi, A., Dal Piaz, G.V., Dal Piaz, G., Massironi, M., Monoppoli, B., Schiavo, A., Toffolon, G. (2011). Geological map sheet 175 Sterzing 1:50.000. Wien: Geologische Bundesanstalt.

Roeder, D., 1989. South Alpine thrusting and trans-Alpine convergence. Geol. Soc. Spec. Publ. 45, 211-227.

Rosenberg CL, Brun J-P, Gapais D, 2004. An indentation model of the Eastern Alps and the origin of the Tauern Window. Geology 32, 997-1000. 
Rosenberg, C.L., Brun, J.-P., Cagnard, F. Gapais, D., 2007. Oblique indentation in the eastern Alps: insights from laboratory experiments. Tectonics 26, doi $10.1029 / 2006 \mathrm{tc} 001960$.

Rosenberg, C.L., Schneider, S., 2008. The western termination of the SEMP Fault (eastern Alps) and its bearing on the exhumation of the Tauern Window. In: Siegesmund, S., Fügenschuh, B., and Froitzheim, N. (eds) Tectonic Aspects of the Alpine-Dinaride-Carpathian System. Geol. Soc. Spec. Publ. 298, 197-218.

Rosenberg, C. L., Berger, A., 2009. On the causes and modes of exhumation and lateral growth of the Alps, Tectonics 28, TC6001, doi10.1029/2008TC002442.

Rosenberg, C.L., Garcia, S., 2011. Estimating displacement along the Brenner fault and orogen parallel extension in the Eastern Alps. Int. J. Earth. Sci. 100, 11291145.

Rosenberg, C.L., Garcia, S., 2012. Reply to the comment of Fügenschuh et al. 2012, on the paper 'Estimating displacement along the Brenner Fault and orogenparallel extension in the Eastern Alps' by Rosenberg and Garcia, 2011, Int. J. Earth. Sci., 101, 1457-1464.

Rosenberg, C.L., Kissling, E., 2013. 3D insight into Alpine collision: lower plate or upper plate indentation?. Geology 41,doi10.1130/G34584.1.

Rosenberg, C.L., Berger, A., Bellahsen, N., Bousquet, R., 2015. Relating orogen-width to shortening, erosion, and exhumation during Alpine collision". Tectonics, 34, 1306-1328, doi:10.1002/2014TC003736.

Royden, L. H., Horvath, F., Burchfiel, B.C., 1982. Transform faulting, extension, and subduction in the Carpathian Pannonian region. Geol. Soc. Am. Bull. 93, 717725.

Sachsenhofer, R.F., Kogler, A., Polesny, H., Strauss, P., Wagreich, M., 2000. The 
Neogene Fohnsforf Basin: Basin formation and basin inversion during lateral extrusion in the Eastern Alps (Austria), Int. J. Earth Sci. 89, 415-430.

Sachsenhofer, R.F., 2001. Syn- and post-collisional heat flow in the Cenozoic Eastern Alps. Int. J. Earth Sciences (Geol. Rundsch.), 90, 579-592.

Sachsenhofer, R.F., Bechtel, A., Reischenbacher, D., Weiss, A., 2003. Evolution of lacustrine systems along the Mur-Mürz fault system in the Eastern Alps (Austria) and implications on source rocks in pull-apart basins. Mar. Petrol. Geol. 20, 83-110.

Sander, B. 1911. Geologische Studien am Westende der Hohen Tauern. 1. Bericht. Denkschr. Akad. Wiss. Wien, math.-natw. Kl. 82, 257-320, Wien.

Scharf, A., Handy, M.R., Favaro, S., Schmid, S.M., Bertrand, A., 2013a. Modes of orogen-parallel stretching and extensional exhumation in response to microplate indentation and roll-back subduction (Tauern Window, Eastern Alps). Int. J. Earth Sci. 102, doi10-1007/500531-013-0894-4.

Scharf, A., Handy, M.R., Ziemann, M.A., Schmid, S.M., 2013b. Peak-temperature patterns of polyphase metamorphism resulting from accretion, subduction and collision (eastern Tauern Window, European Alps) - a study with Raman microspectroscopy on carbonaceous material (RSCM). J. metamorph. Geol. 31, 863-880.

Scharf, A., Handy, M.R., Schmid, S.M., Favaro, S., Sudo, M., Schuster, R., Hammerschmidt, K., 2016. Grain-size effects on the closure temperature of white mica in a crustal-scale extensional shear zone - Implications of in-situ 40Ar/39Ar laser-ablation of white mica for dating shearing and cooling (Tauern Window, Eastern Alps). Tectonophysics 674, 210=226, doi10.1016/j.tecto.2016.02.014. 
Schiavo, A., Dal Piaz, G.V., Monopoli, B., Bistacchi, A., Dal Piaz, G., Massironi, M., and Toffolon, G., 2015, Geology of the Brenner Pass-Fortezza transect, Italian Eastern Alps Journal of Maps, 11, 201-215.

Shin, Y.H., et al., 2015, Moho topography, ranges and folds of Tibet by analysis of global gravity models and GOCE data. Nature scientific reports, 5, Article number: 11681, DOI: 10.1038/srep11681.

Schmid, S.M., Berza, T., Diaconescu, V., Froitzheim, N., Fügenschuh, B., 1998. Orogenparallel extension in the Southern Carpathians, Tectonophysics 297, 209-228.

Schmid, S.M., Fügenschuh, B., Kissling, E., Schuster, R., 2004. Tectonic map and overall architecture of the Alpine orogen. Eclogae geol. Helv. 97, 93-117.

Schmid S.M., Scharf, A., Handy, M.R., Rosenberg, C.L., 2013. The Tauern Window (Eastern Alps. Austria): a new tectonic map, with cross sections and a tectonometamorphic synthesis. Swiss J. Geosci. 106, 1-32.

Schneider, S., Hammerschmidt, K., Rosenberg, C.L., 2013. Dating the longevity of ductile shear zones: insight from ${ }^{40} \mathrm{Ar} /{ }^{39} \mathrm{Ar}$ in situ analyses. Earth Planet. Sci. Lett. 369, 43-58. doi10.1016/j.epsl.2013.03.002.

Schneider, S., 2014, Exhumation mechanisms of middle and lower crust in the western Tauern Window, Eastern Alps. PhD Thesis, pp. 151, Freie Universität Berlin, Germany.

Schneider, S., Hammerschmidt, K., Rosenberg, C.L., Gerdes, A., Frei, D., Bertrand, A., 2015. U-Pb ages of apatite in the western Tauern Window (Eastern Alps): Tracing the onset of collision-related exhumation in the European plate. Earth Planet. Sc. Lett. 418, 53-65.

Schönborn, G., 1999. Balancing cross sections with kinematic constraints: The Dolomites (northern Italy). Tectonics, 18, 527-545. 
Schuster, R., Pestal, G., Reitner, J.M., 2006. Erläuterungen zu Blatt 182 Spittal an der Drau. Geol. B.-A. Wien.

Scolari, A., \& Zirpoli, G. (1972). Filoni tardoalpini metamorfici negli scisti austridici e pennidici della Val di Valles (Alto Adige). Memorie Istituti Geologia e Mineralogia dell'Universita`di Padova, 29, 1-32.

Selverstone, J., 1988. Evidence for east-west crustal extension in the Eastern Alps: implications for the unroofing history of the Tauern Window. Tectonics 7, 87105.

Selverstone, J., 1993. Micro- to macroscale interactions between deformational and metamorphic processes, Tauern Window, Eastern Alps. Schweiz. Min. Petr. Mitt. 73, 229-239.

Selverstone, J., Axen, G., Bartley, J., 1995. Fluid inclusion constraints on the kinematics of footwall uplift beneath the Brenner line normal fault, Eastern Alps. Tectonics, 14, 264-278.

Sissingh, W., 2006. Syn-kinematic palaeogeographic evolution of the West European Platform: correlation with Alpine plate collision and foreland deformation. Netherlands Journal of Geosciences — Geologie en Mijnbouw, 85, 131 - 180.

Spada, M., Bianchi, I., Kissling, E., Piana Agostinetti, N. Wiemer, S., 2013. Combining controlled-source seismology and receiver function information to derive 3-D Moho topography for Italy. Geophys. J. Int. 194, 1050-1068. doi 10.1093/gji/ggt148.

Sperner, B., Ratschbacher, L., Nemcok. M., 2002. Interplay of lateral extrusion, subduction rollback, and continental collision in the Teriary evolution of the Western Carpathians. Tectonics, 21, 1051, doi10.1029/2001TC901028. 
Staufenberg, H., 1987. Apatite fission track evidence for postmetamorphic uplift and cooling history of the eastern Tauern Window and the surrounding Austroalpine (Central Eastern Alps, Austria). Jb. geol. B.-A. 130, 571-586.

Steck, A., 1980. Deux directions principales de flux synmétamorphique dans les Alpes centrales. Bull. Soc. Vaudoise Sci. natur. Fr. 75, 141-149.

Steenken, A., Siegesmund, S., Heinrichs, T., Fügenschuh, B., 2002. Cooling and exhumation of the Rieserferner Pluton (Eastern Alps, Italy/Austria). Int. J. Earth Sci. 91, 799-817.

Stöckhert, B., Brix, M.R., Kleinschrodt, R., Hurford, A.J., Wirth, R., 1999. Thermochronometry and the microstructures of quartz-A comparison with experimental flow laws and predictions on the temperature of the brittleplastic transition: J. struct. Geol. 21, 351-369, doi10.1016/S01918141(98)00114-X

Stöckli, D.F., 2005. Application of low-temperature thermochronometry to extensional tectonic settings. In: Reiners, P., and Ehlers, T. (eds.), Thermochronometry. Reviews in Mineralogy and Geochemistry, vol. 58, p. $420-461$.

Studer, B., 1851, Geologie der Schweiz. Stämpflische Verlagshandlung. Bern.

Tapponnier, P., Peltzer, G., Le Dain, A.Y., Armijo, R., Cobbold, P., 1982. Propagating extrusion tectonics in Asia: New insights from simple experiments with plasticine, Geology 10, 611-616.

Termier, P., 1903. Les nappes des Alpes Orientales et la Synthese des Alpes. Société géologique de France 4, 711-765.

Thiele, 0., 1970, Zur Stratigraphie und Tektonik der Schieferhülle der westlichen Hohen Tauern. In: Verhandlungen der Geolischen Bundes-Anstalt. Wien 1970, 
Thiele, O., 1976, Der Nordrand des Tauernfensters zwischen Mayrhofen und Innern Schmirn (Tirol). Geologische Rundschau, 65, 410-421.

Thiele O., 1980. Das Tauernfenster. In Oberhauser R. (Ed): Der geologische Aufbau Oesterreichs, Springer, pp. 300-314.

Thöni, M., 1999. A review of geochronical data from the Eastern Alps. Schweiz. Min. Petr. Mitt. 79, 209-230.

Tikoff, B., Teyssier, C., 1994. Strain modeling of displacement-field partitioning in transpressional orogens. J. Struct. Geol. 16, 1575-1588.

Tollmann, A., 1962. Der Baustil der tieferen tektonischen Einheiten der Ostalpen. Int. J. Earth Sci. 52, 226-237.

Tollmann, A., 1980. Das östliche Tauernfenster. Mitt, österr. geol. Ges. 71, 73-79.

Tollmann, A., 1986. Die Entwicklung des Reliefs der Ostalpen, Mitt. Österr. Geogr. Ges., 128,62-72.

Van Gelder, I., 2017, Interfering orogenic processes derived from Alps-Adria interactions, PhD Univesity of Amsterdam, Netherlands, Utrecht Studies in Earth Sciences, 125, ISBN: 978-90-6266-449-8

van Gelder, I, Willingshofer, E., Sokoutis, D., and Cloetingh, S.A.P.L., 2017, The interplay between subduction and lateral extrusion: A case study for the European Eastern Alps based on analogue models. Earth and Planetary Science Letters, 472, 82-94.

Vergés, J., Saura, E., Casciello, E., Fernàndez, E., Villaseñor, A., Jiménez-Munt, I., and García-Castellanos, D., 2011. Crustal-scale cross sections across the NW Zagros belt: implications for the Arabian margin reconstruction, 2011, Geol. Mag. 148, 739-761. doi10.1017/S0016756811000331. 
Veselá, P., Lammerer, B., Wetzel, A., Söllner, F. \& Gerdes, A. 2008. Post-Variscan to Early Alpine sedimentary basins in the Tauern Window (eastern Alps). In: Siegesmund, S. et al. (Eds.): Tectonic Aspects of the Alpine-DinarideCarpathian System. Geological Society, London, Special Publications, 298, 83100.

Viola, G., Mancktelow, N.S., Seward, D., 2001. Late Oligocene-Neogene evolution of Europe-Adria collision: New structural and geochronological evidence from the Giudicarie fault system (Italian Eastern Alps). Tectonics 20, 999-1020.

Viola, G., Mancktelow, N.S., Seward, D., Meier, A., Martin, S., 2003. The Pejo fault system: An example of multiple tectonic activity in the Italian Eastern Alps. Geol. Soc. Am Bull. 115, 515-532.

von Blanckenburg, F., Villa, I.M., Baur, H., Morteani, G., Steiger, R.H., 1989. Time calibration of a PT path from the Western Tauern Window, Eastern Alps: the problem of closure temperatures. Contrib. Mineral. Petrol.101-111.

Wagner, R., Rosenberg, C.L., Handy, M.R., Möbus, C., Albertz, M., 2006. Fracturedriven intrusion and upwelling of a mid-crustal pluton fed from a transpressive shear zone: the Rieserferner pluton (Eastern Alps). Geol. Soc. Am. Bull. 118, 219-237, doi10.1130/B25842.1.

Wawrzyniec, T.F., Selverstone, J., Axen, G., 2001. Styles of footwall uplift along the Simplon and the Brenner normal fault systems, central and Eastern Alps. Tectonics, 20, 748-770.

Wernicke, B., Axen, G.J., 1988. On the role of isostasy in the evolution of normal fault systems. Geology, 16, 848-851.

Wölfler, A., Dekant, C., Danisìk, M., Kurz, W., Dunkl, I., Putis, M., Frisch, W., 2008. Late stage differential exhumation of crustal blocks in the central Eastern Alps: 
evidence from fission track and (U-Th)/He thermochronology. Terra Nova $20,378-384$.

Wölfler, A., Kurz, W., Danisık, M., Rabitsch, R., 2010. Dating of fault zone activity by apatite fission track and apatite (U-Th)/He thermochronometry: a case study from the Lavanttal fault system (Eastern Alps). Terra Nova 22, 274282.

Wölfler, A., Kurz, W., Fritz, H., Stüwe, K., 2011. Lateral extrusion in the Eastern Alps revisited: Refining the model by thermochronological, sedimentary, and seismic data. Tectonics 30, doi10.1029/2010TC002782.

Wölfler, A., W. Frisch, H. Fritz, M. Danisik, and A. Wolfler, 2015, Ductile to brittle fault zone evolution in Austroalpine units to the southeast of the Tauern Window (Eastern Alps). Swiss J. Geosci. 108, 239-251, DOI 10.1007/s00015015-0193-0.

Xu, Z., Wang, Q., Pêcher, A., Liang, F., Qi, X., Cai, Z., Li, H., Zeng, L., Cao, H., 2013. Orogen-parallel ductile extension and extrusion of the Greater Himalaya in the late Oligocene and Miocene. Tectonics 32, 191-215, doi10.1002/tect.20021.

Zhao, L., Paul, A., Malusà, M., Xu, X., Zheng, T., Solarino, S., Guillot, S., Schwartz, S., Dumont, T., Salimbeni, S., Aubert, C., Pondrelli, S., Wang, Q., and Zhu, R., 2016, Continuity of the Alpine slab unraveled by high-resolution $\mathrm{P}$ wave tomography, J. Geophys. Res. Solid Earth, 121, doi:10.1002/2016JB013310

Zimmermann, R., Hammerschmidt, K., Franz, G., 1994. Eocene high pressure metamorphism in the Penninic units of the Tauern Window (Eastern Alps) evidence from $\mathrm{Ar}^{40}-\mathrm{Ar}^{39}$ dating and petrological investigations. Contrib. Mineral. Petr. 117, 175-186. 
Zweigel, P., 1998, Arcuate accretionary wedge formation at convex plate margin corners: results of sandbox analogue experiments. Journal of Structural Geology, 20, 1597-1609. 